Geologic Evaluation of Waste-Storage Potential In Selected Segments of the Mesozoic Aquifer System Below the Zone of Fresh Water, Atlantic Coastal Plain, North Carolina Through New Jersey

GEOLOGICAL SURVEY PROFESSIONALAAPER 881 Sponsored by the Department of Defense

Defense Advanced Research Projects

Agency, DARPA Order No. 1813, Amendment No. 1

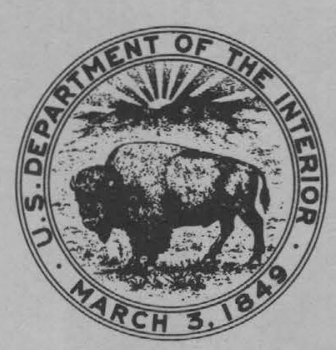


Geologic Evaluation of Waste-Storage Potential In Selected Segments of the Mesozoic Aquifer System Below the Zone of Fresh Water, Atlantic Coastal Plain, North Carolina Through New Jersey

By PHILIP M. BROWN and MARJORIE S. REID

GE OL O I G A L S U R E Y PROFESSIONAL PAPER 881

Sponsored by the Department of Defense

Defense Advanced Research Projects

Agency, DARPA Order No. 1813,

Amendment No. 1

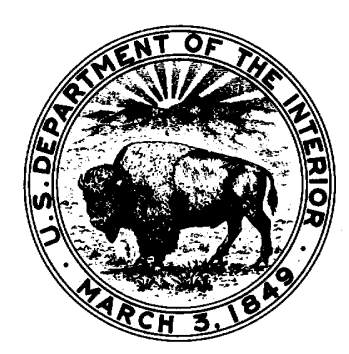




\section{UNITED STATES DEPARTMENT OF THE INTERIOR}

THOMAS S. KLEPPE, Secretary

GEOLOGICAL SURVEY

V. E. McKelvey, Director

\section{Library of Congress Cataloging in Publication Data}

Brown, Philip Monroe.

Geologic evaluation of waste-storage potential in selected segments of the Mesozoic aquifer system below the zone of fresh water, Atlantic Coastal Plain, North Carolina through New Jersey.

(Geological Survey professional paper 881)

"Sponsored by the Department of Defense, Defense Advanced Research Projects Agency, DARPA order no. 1813, amendment no. 1."

Bibliography: p.

Supt of Docs. no.: I 19.16:881

1. Geology-Middle Atlantic States. 2. Aquifers-Middle Atlantic States. 3. Geology, Stratigraphic-Mesozoic. 4. Waste disposal in the ground-Middle Atlantic States. I. Reid, Marjorie S., joint author. II. Title. III. Series: United States. Geological Survey. Professional paper 881. QE78.3.B7 557.5 74-16110

For sale by the Superintendent of Documents, U.S. Government Printing Office Washington, D.C. 20402

Stock Number 024-001-02738-1 


\section{CONTENTS}

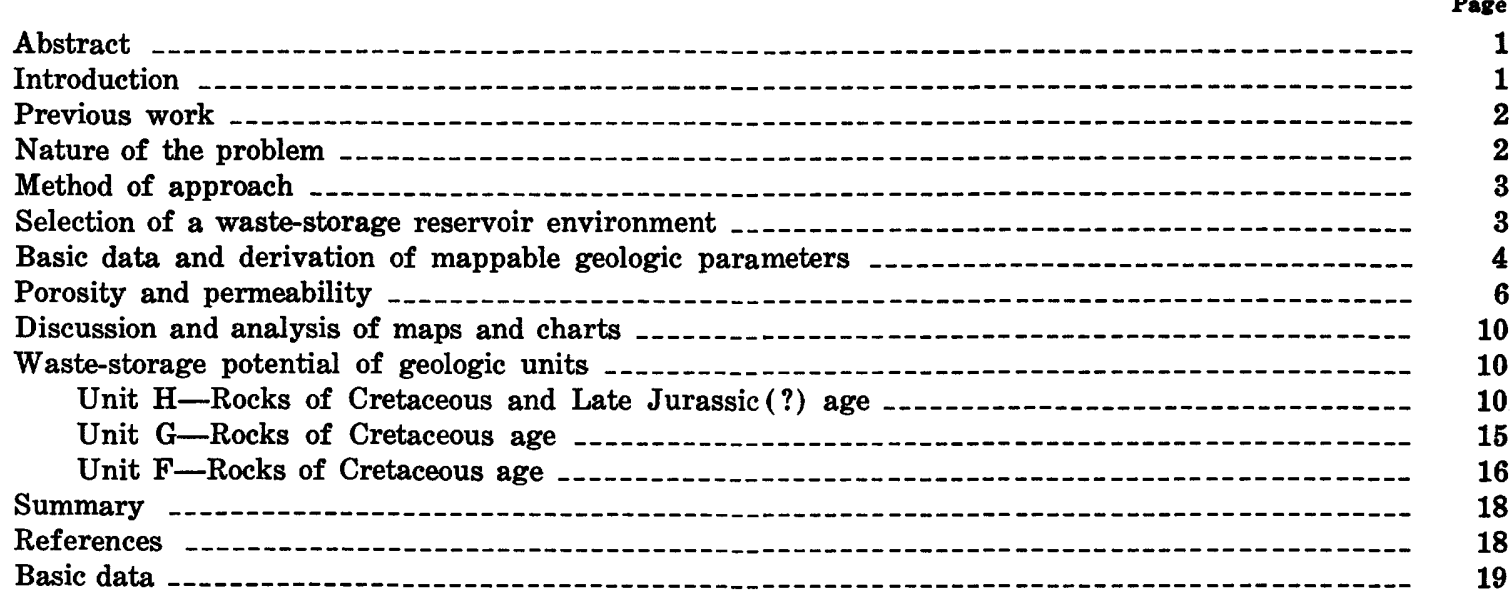

\section{ILLUSTRATIONS}

[Plates follow text in case]

Plate 1. Location map for key wells and geologic sections, Atlantic Coastal Plain, North Carolina to New York.

2-4. Geohydrologic maps, Unit $\mathbf{H}$ of Cretaceous and Late Jurassic(?) age, Atlantic Coastal Plain, North Carolina to New Jersey:

2. Averaged depth to the tops of the unit's potential waste-reservoir sands and unit thickness and sand thickness.

3. Thickness of potential waste-reservoir sand and averaged thickness, per foot of potential wastereservoir sand, for shale seals that immediately overlie the reservoir sands.

4. Averaged thickness, per foot of potential waste-reservoir sand, for the shale seals that immediately underlie the reservoir sands and Depth/Potential Reservoir factor.

5-7. Geohydrologic maps, Unit $G$ of Cretaceous age, Atlantic Coastal Plain, North Carolina to New Jersey:

5. Averaged depth to the tops of the unit's potential waste-reservoir sands and unit thickness and sand thickness.

6. Thickness of potential waste-reservoir sand and averaged thickness, per foot of potential wastereservoir sand, for shale seals that immediately overlie the reservoir sands.

7. Averaged thickness, per foot of potential waste-reservoir sand, for the shale seals that immediately underlie the reservoir sands and Depth/Potential Reservoir factor.

8-10. Geohydrologic maps, Unit F of Cretaceous age, Atlantic Coastal Plain, North Carolina to New Jersey:

8. Averaged depth to the tops of the unit's potential waste-reservoir sands and unit thickness and sand thickness.

9. Thickness of potential waste-reservoir sand and averaged thickness, per foot of potential wastereservoir sand, for shale seals that immediately overlie the reservoir sands.

10. Averaged thickness, per foot of potential waste-reservoir sand, for the shale seals that immediately underlie the reservoir sands and Depth/Potential Reservoir factor. 
FIGURES 1-5. Graphs of Units F, G, and $H$ showing:

1. Ratio of the unit's potential waste-reservoir sand thickness to unit's total sand thickness

2. Ratio of the unit's sand thickness to unit's shale thickness

3. Number of potential waste-reservoir sands occurring per well

4. Maximum thickness of potential waste-reservoir sands, according to percent well occurrence -..--

5. Potential waste-reservoir sands in upper third, middle third, and lower third of unit, according to percentage well occurrence

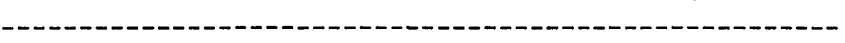

\section{TABLES}

1. Core analyses for Unit G, Standard Oil of New Jersey, Hatteras Light No. 1, Dare County, N.C. (NC-DA-OT-10)

2. Summary of selected waste-storage data, Units F, G, and $\mathrm{H}$ 


\title{
GEOLOGIC EVALUATION OF WASTE-STORAGE POTENTIAL IN SELECTED SEGMENTS OF THE MESOZOIC AQUIFER SYSTEM BELOW THE ZONE OF FRESH WATER, ATLANTIC COASTAL PLAIN, NORTH CAROLINA THROUGH NEW JERSEY
}

\author{
By Philip M. Brown and Marjorie S. Reid
}

\begin{abstract}
ABSTRAGT
This report describes the distribution of subsurface environments in the Atlantic Coastal Plain-North Carolina through New Jersey, that are seen to have geologic potential for the storage of toxic waste. The environments described consist of layers of sand or sandstone, 20 feet or more in thickness, that are immediately overlain and underlain by layers of shale or clay, 20 feet or more in thickness, and which occur in Units $\mathbf{F}, \mathbf{G}$, and $\mathrm{H}$ of Mesozoic age in areas where the top of each of these units lies at a depth equal to or greater than 1,500 feet below mean sea level.

Using a group of geologic parameters derived from or combining 20 categories of basic data, established from study of well cuttings and geophysical logs, a series of 18 regional maps was constructed. For each of three geologic units delineated in the subsurface, the maps illustrate the distribution of potential waste-storage reservoirs in terms of their areal extent, depth below land surface, and the thicknesses of the component reservoir and reservoir-seal rocks.

The depth of burial, physical character, and extent and thickness of the reservoirs that have waste-storage potential are variable. The range in variability appears to be broad enough to satisfy the geologic requirements for different types of waste storage.
\end{abstract}

\section{INTRODUCTION}

In the past and to a limited extent, the void space (porosity) in underground rocks has been used as a receptacle in which to inject waste that was obnoxious or detrimental when stored or dispersed at the land surface. Today, significant increase in the volume and detrimental components of waste products, coupled with increasing demand for a clean environment, has led government and industry to give additional consideration to this void space as a possible storage reservoir for some types of fluid wasteespecially those that are toxic and will remain so for a long time.

To determine the volume of void space available and to consider its use for this purpose, those con- cerned with waste management must be able to forecast the waste-storage potential of different rock layers underground (their capacity to receive and retain various types and volumes of waste), to assess cost-risk-benefit factors associated with potential sites, and to select experimental and operational sites for waste injection. To make these forecasts, assessments, and selections, management must have certain geologic, hydrologic, chemical, and engineering information that defines the physical-chemical boundaries and complexities of subsurface environments.

To evaluate the waste-reservoir potential of underground sediments both general and specific geologic information is required. The general information required is that which will provide an understanding of the geometry of the sediment mass, the conditions extant during its emplacement, and how it was affected and modified by tectonic and structural events during and after its emplacement. The specific geologic information required is that which will delineate rocks of high porosity and permeability (potential waste-storage reservoirs) and rocks of low permeability (potential waste-storage reservoir seals), describe their external and internal geometry and their relative spatial distribution within the sediment mass.

Some of this information may be obtained by analysis, interpretation, and extrapolation of stratigraphic and geophysical data from a relatively few, widely scattered boreholes. Other required information may be derived only from data obtained from closely spaced boreholes and cored geologic sections.

Interpretation of the data from widely scattered boreholes serves several purposes. It provides a relatively rapid and inexpensive method for the screening of large geographic areas to delineate favorable 
waste-reservoirs. Thus, it identifies the areas where the drilling of closely spaced boreholes will be required and where they will have the greatest chance of success in defining waste reservoirs. Also, it identifies areas to be considered in locating industrial sites that may require nearby facilities for subsurface waste disposal. Most importantly, interpretation of these data permits the definition and presentation of quantitative geologic parameters that are the base for establishing hydrologic, chemical, and engineering correlation and prediction.

Accordingly, in September 1971, as part of the U.S. Geological Survey's waste-storage research program and using the data available from a relatively few widely spaced boreholes, an investigation was begun to evaluate the waste-storage potential of selected segments of the Mesozoic aquifer system in that part of the Atlantic Coastal Plain extending from North Carolina through New Jersey. This is the report of the investigation.

This research was supported by the Defense Advanced Research Projects Agency and was monitored by the U.S. Geological Survey under Order No. 1813, Amendment No. 1.

The work was done under guidelines established by the Chief Hydrologist of the U.S. Geological Survey.

The opinions and conclusions contained in this report are those of the senior author and should not be interpreted as necessarily representing the official policies, either expressed or implied, of the Defense Advanced Research Projects Agency or of the U.S. Geological Survey.

\section{PREVIOUS WORK}

A comprehensive annotated bibliography for the storage of liquids underground was compiled by Rima, Chase, and Myers (1971). The geologic requirements for storage are described in many publications, including those written or edited by Russell (1960); Katz, Tek, Coats, Katz, Jones, and Miller (1963) ; Young and Galley (1965) ; Katz and Coats (1968); Witherspoon, Javandel, Neuman, and Freeze (1967); Galley (1968); and Cook (1972).

Many of the basic data used to prepare this report were included in or were assembled during preparation of a report by Brown, Miller, and Swain (1972). The earlier report provides the general and many of the specific geologic data required to make an evaluation of waste-storage potential in the study area. It contains analyses of the regional stratigraphic framework, the spatial arrangement of sedi- ments within that framework, and the regional distribution of intrinsic permeability as a function of lithologic variance. It integrates the tectonic, structural, and sedimentary historical events in the region and provides an understanding of its geologic complexities. In addition, it provides type-reference and lithologic-reference sections in the subsurface for the geologic units herein considered to have wastestorage potential.

The present report uses the key-well network defined in the earlier report, to which recently drilled wells have been added, and it expands the discussion of the sedimentary geometry in the earlier report to define, in greater detail, the sand-shale relations that apply specifically to delineation of potential wastestorage reservoirs. For practical reasons, the earlier report, with its maps and geologic sections, should be used in conjunction with the present report. To facilitate this conjunctive use, the well-location map in this report (pl. 1) is an updated version of a map (pl. 4) in the earlier report that shows the locations of all key wells in the study area and of lines of geologic sections.

\section{NATURE OF THE PROBLEM}

The primary research problem was to select and map favorable waste-reservoir environments in the Atlantic Coastal Plain study area. The problem included several interconnected elements as follows:

1. Given a large geographic area that contained scattered borehole data, to select criteria and develop techniques that would permit rapid and inexpensive screening of the study area for potential waste-storage reservoirs, whose initial selection or rejection could be guided by a set of quantitative mappable geologic parameters.

2. In the absence of information about the specific volumes and types of waste that might be available for injection into the subsurface, to select those geologic parameters whose cartographic presentation could be interpreted to indicate the types of reservoirs available for storage of different volumes and kinds of waste throughout the region.

3. Using the Atlantic Coastal Plain as a prototype area, to apply the selected criteria and techniques to evaluation of potential wastereservoirs in such a manner that the methodology and results could be used by management to derive guidelines for defining and delineating similar environments in 
other geographic areas underlain by clastic sedimentary geological formations.

\section{METHOD OF APPROACH}

Viewed broadly, the fundamental processes that take place in a subsurface waste-storage reservoir consist of complex interactions between the substance injected, the physical and chemical components of the reservoir and its boundary rocks, and the native fluid, liquid or gaseous, that is being compressed within or forced out of the reservoir by the pressure on the injected substance.

The principal geologic problem in evaluating subsurface waste-storage potential is to locate and describe rocks that have the potential capacity either to store or contain waste in areas where these interactions, some of which are unknown or undefinable at present, may take place without producing harmful side effects. Rocks that may have potential as waste reservoirs or reservoir seals for toxic waste are deeply buried and have locally differing geometries and degrees of chemical complexity. Therefore, a direct approach to solution of the problem, the drilling of closely spaced core holes, is prohibitive from a cost standpoint alone. An indirect approach is necessary. From the subsurface environments present in the region, an environment is selected that has the potential for meeting the geologic requirements for injection, storage, and containment of waste. The occurrences and pattern of distribution of potential reservoirs can then be shown by a set of quantitative geologic parameters which can be plotted directly on maps and charts. This indirect method of regional evaluation of waste-reservoir potential is used in this report. The principle or screening mechanism involved, applied commonly in exploration geology, is that the chances for locating suitable waste-reservoirs are much greater if the search concentrates in areas where waste-reservoirs are most abundant. The minimum prerequisites needed to use this exploration method in the study area are:

1. Definition of the geometry of the sediment mass in order that its component environments can be recognized and classified, both genetically and physically.

2. Availability of lithologic and geophysical data that can be used to derive geologic parameters which have a relation to the geometry of potential waste reservoirs and which can be plotted on maps and charts.

3. Information about the geologic complexities of the study area that is sufficient to permit data extrapolation using data available from a minimum of boreholes.

\section{SELECTION OF A WASTE-STORAGE RESERVOIR ENVIRONMENT}

In the study area the basic geologic requirements for selection of a potential waste-reservoir environment are its depth of burial, physical character, areal extent and thickness, and hydrological isolation.

The environment must be present at a depth that precludes any possible contamination of fresh-water resources and where any waste introduced into the subsurface will not be a detriment to the recovery or in situ use of other underground resources.

The selected environment must have two types of rock, with one type (characterized by a relative high porosity and permeability, and sufficient thickness and lateral extent to qualify as a potential reservoir) being immediately underlain and overlain by the second type (characterized by relative low permeability, an absence of fractures, and sufficient thickness and lateral extent to qualify as a reservoir seal). The candidate reservoir rock may have either a high or a low waste-sorption potential, depending upon the nature of the injected fluid, its storage requirements, and optimum rates and volumes of injection.

Ideally, the reservoir rock should be connected laterally with rock having the capacity to accept the native fluid that moves out of reservoir storage in response to injection pressure. This arrangement would reduce the danger of fracturing and breaching of the reservoir seals.

In the study area, as shown by analysis of the sediment mass (Brown and others, 1972), relatively porous and permeable layers of sand are the only deeply buried rocks having sufficient thickness, areal extent, and degree of interconnection to qualify as potential waste reservoirs regionally. Other relatively porous and permeable rocks in the sediment mass, such as limestone or dolomite, either are too near the land surface or do not have the requisite thickness or areal extent to qualify. Similarly, layers of relatively impermeable shale are the only deeply buried rocks in the sediment mass having sufficient thickness and areal extent to qualify as potential waste-reservoir seals regionally.

Taking these two rock types and postulating their arrangement within the desired waste-reservoir configuration, which dictates that the relatively porous 
and permeable rock must be immediately underlain and overlain by relatively impermeable rock, and imposing an economic constraint and a general safety constraint, we can define a potential wastestorage reservoir environment quantitatively and map its occurrence throughout the study area. A preliminary definition of this environment is as follows :

A sand or sandstone layer 20 feet or more in thickness that is directly underlain and overlain by a shale or clay layer 20 feet or more in thickness.

The minimum thickness of 20 feet for a sand layer is an economic constraint imposed by exploration and development requirements. The minimum thickness of 20 feet for underlying and overlying shale layers is a safety constraint imposed by the minimum thickness judged to be required for a reservoir confining layer (Russell, 1960).

On the basis of their distribution in the subsurface and their sand-shale geometry, three geologic units of Mesozoic age seemed to have the greatest potential for containing waste-storage reservoirs in the study area. They are Units F, G, and H. These units, which range from Early Cretaceous to Early Cretaceous-Jurassic(?) in age, were described, mapped, and illustrated in stratigraphic cross sections by Brown, Miller, and Swain (1972, pls. 7-9).

The requirement that fresh-water systems be protected from natural or induced contamination by injected waste limits the waste-storage potential of these geologic units to their more deeply buried segments that contain saline water. Seemingly, this constraint requires determination of the location of the fresh-saline water boundary zones within these units. In the study area and except in a general way, the point-source data required to make this determination either are not available or have not been correlated using a valid geologic base. Therefore, to be reasonably certain that the environments considered to have waste-storage potential contain saline water, it is necessary to add a safety or depthof-burial factor to the known or projected depth of fresh-water occurrence in these geologic units.

From a background of knowledge gained through a study of the geohydrology of the region for more than 20 years, we judge that Units F, G, and $H$ generally may contain fresh water to a depth of as much as 600 feet below mean sea level. Locally, and especially in the case of Unit F, they may contain fresh water to a depth of as much as 1,000 feet below mean sea level. Thus, the constraint imposed by the approximate maximum depth of fresh-water occurrence in these units is about 1,000 feet below mean sea level. On maps in this report (pls. 2, 5, and 8) this boundary is labeled and is defined as the projected maximum depth of fresh-water occurrence. We consider a satisfactory added safety or depth-of-burial factor to be $\mathbf{5 0 0}$ feet below mean sea level, one-half of the projected maximum depth of fresh-water occurrence. Thus, the depth-ofburial safety factor, 500 feet below mean sea level, added to the projected depth of fresh-water occurrence, 1,000 feet below mean sea level, gives a depth of 1,500 feet below mean sea level as the projected depth at which all the potential waste-storage reservoir environments in Units $F, G$, and $\mathrm{H}$ may be expected to contain saline water. On maps in this report (pls. 2-10) this boundary is labeled and is defined as the projected minimum depth of salinewater occurrence.

Identification of these new constraints imposed by selection of specific geologic units and a required depth-of-burial factor permits us to amend our previous definition of a potential waste-storage reservoir to read as follows :

$A$ sand or sandstone layer 20 feet or more in thickness that is directly underlain and overlain by a shale or clay layer 20 feet or more in thickness and which occurs in Units F, G, and $H$ where the top of each of these units lies at a depth of 1,500 feet or more below mean sea level

Within the constraints imposed by the amended definition, and using the data from widely scattered boreholes, it is now possible to establish a set of quantitative geologic parameters and use them to map the distribution of this environment in selected segments of the study area.

\section{BASIC DATA AND DERIVATION OF MAPPABLE GEOLOGIC PARAMETERS}

The selection of segments of Units $F, G$, and $H$ for evaluation of waste-reservoir potential is based on their distribution in the subsurface, their sandshale geometry, and projection of the occurrence of saline water in them.

Within or adjacent to areas where the tops of these units lie at depths of 1,500 feet or more below mean sea level, 51 wells pentrate Unit F, 44 wells penetrate Unit $G$, and 31 wells penetrate Unit $H$. These wells comprise the key-well network in the waste-reservoir evaluation study. Their location and the locations of what we consider to be other key stratigraphic wells in the North Carolina-New Jersey segment of the Atlantic Coastal Plain are shown on plate 1. Geologic data for wells in the keywell network are listed on well-data sheets in this report. 
On these sheets, the wells in the network are identified in the manner described by Brown, Miller, and Swain (1972, p. 35-36) and by a record number. This number is an identifying number for the well data stored in the U.S. Geological Survey's computer record file which contains more complete geologic data for the well than given in this report. These data, in automated form are available upon written request to the Chief Hydrologist, U.S. Geological Survey, National Center, Reston, Va. 22092. The request should list the record numbers for the wells for which data are desired and should specify if the data are desired in the form of printed tables, magnetic tape, or punched cards. The original geophysical logs for the key wells used in the waste-reservoir study are available in the offices of the State Geologists in the States where the wells are located and in the U.S. Geological Survey Office, 3509 Haworth Dr., Raleigh, N.C. 27609.

Definition of the potential waste-reservoir environment (see preceding section) was followed by delineation of the environment in the wells available for study. Using a combination of lithologic, geophysical, and paleontologic data, a top and a thickness was established for Units $F, G$, and $H$ in the wells that comprise the key-well network. In each well, the stratigraphic column for these units was evaluated in terms of the number of occurrences and thicknesses of the unit's sand, shale, and carbonate components. This evaluation was made by analysis of lithologic logs. The logs were constructed on the basis of microscopic examination of well cuttings and by construction of a "shale line" and a "sand line" on the Self Potential curve of electric logs and by analysis of Gamma-Ray curves of radioactivity $\log _{\mathrm{s}}$. The thicknesses of sand and shale were scaled off the logs and were entered on the well-data sheets or computed as ratios and percentages. In a similar manner, the potential waste-reservoir environments were identified. Their number and the thickness of their component sand and shale parts were scaled off the $\operatorname{logs}$ and entered on the well-data sheets.

The entries on the well-data sheets consist of 20 categories of data that relate either to the depth of occurrence or thicknesses of the three geologic units, to the depth of occurrence or thickness of the unit's sand and shale components, or to useful combinations of these data. The 20 categories of data were used directly or were combined or averaged so as to derive quantitative geologic parameters that could be mapped or graphed to show the occurrence and distribution of potential waste-storage reservoirs in the study area.

For each of the three geologic units considered to have waste-storage potential, six maps were constructed as follows :

1. Averaged depth to the tops of the unit's potential waste-reservoir sands.

A plot of the altitude of the top of the unit was contoured, using the minus 1,000 -foot altitude (the projected maximum depth of freshwater occurrence), the minus 1,500-foot altitude (the projected minimum depth of salinewater occurrence), and 500-foot increments of altitude below minus 1,500 feet. The altitude of the top of each potential reservoir sand at a given control point was determined. These altitudes were then averaged, plotted, and contoured. The resulting regional map shows the contoured average depth for the tops of the unit's potential waste-reservoir sands superimposed on the contoured depth of the top of the unit.

2. Unit-thickness and sand thickness map.

This map was constructed by obtaining values for the thickness of the unit at given control points and contouring these values on a regional base. In a similar manner, values for sand thickness were contoured. The resulting regional map shows total sand thickness superimposed on total unit thickness.

3. Map of thickness of potential waste-reservoir sand.

The map was constructed by determining the thickness of each potential reservoir sand at a given control point, obtaining an average thickness value for the sand at that control point, and mapping the extent of the average thickness by means of six categories. The resulting map shows the relative thickness of potential waste-reservoir sand regionally.

4. Map showing the averaged thickness, per foot of potential waste-reservoir sand, for the shale seals that immediately overlie the reservoir sands.

The map was constructed by calculating the ratio/thickness value, in feet, of overlying shale or clay seal per foot of reservoir sand for each potential waste-reservoir at each control point. These values were then averaged for each control point. The averaged value was assigned to one of four categories on an arbitrary thickness scale, and the extent of each 
category was mapped on a regional base. The resulting regional map shows the relative thickness of the overlying shale or clay seal per foot of reservoir sand in areas where potential waste-reservoirs have been delineated.

5. Map showing the averaged thickness, per foot of reservoir sand, for the shale seals that immediately underlie the reservoir sands.

The map was constructed in a manner similar to that described for map 4.

6. Map of Depth/Potential Reservoir factor.

The map was constructed by calculating an averaged value for the depth to the tops of the potential waste-reservoir sands at a given control point and dividing this calculated average value by the total measured thickness of potential reservoir sand at the given control point. The resulting number, designated a Depth/Potential Reservoir factor and representing feet of overburden per foot of potential reservoir sand at a given control point, was assigned to one of six categories on an arbitrary footage scale. The scaled categories were then delineated on a regional base map. The resulting map shows the comparative thickness of overburden per foot of potential reservoir sand in areas where potential wastestorage reservoirs have been delineated.

For each of the three units considered to have waste-storage potential, graphs were prepared to supplement the data shown on the maps. The geologic parameters graphed, according to the percentage or to the number of wells in which they occur, are:

1. Ratio of unit's potential waste-reservoir sand thickness to unit's total sand thickness.

2. Ratio of unit's sand thickness to unit's shale thickness.

3. Number of potential waste-reservoir sands.

4. Maximum thickness of potential waste-reservoir sands.

5. Occurrence of potential waste-reservoir sands in upper third, middle third, and lower third of unit.

The various maps and graphs are discussed in the following section relative to their utility in defining potential waste reservoirs. In conjunction with other information, the discussions may serve as a geologic guide for future planning of waste-storage or other types of subsurface-storage facilities. They do not provide ultimate answers to questions about the possibility of waste storage in the reservoirs under consideration.

\section{POROSITY AND PERMEABILITY}

In evaluating potential waste-storage environments, two of the more important properties to be considered are a rock's effective porosity and permeability. The effective porosity of a rock is its volumetric percentage of connected voids. The permeability of a rock is a measure of the relative ease with which it transmits fluid through its interconnected pores. A magnitude for permeability, generally expressed in darcies or millidarcies, in wastestorage evaluation, is determined by the rate at which a fluid of standard viscosity moves through a given rock distance during a given interval of time. Permeability cannot exist in the absence of porosity, but porosity may exist in the absence of permeability.

The porosity and permeability requirements for rocks that have waste-reservoir and waste-reservoir seal potential, respectively, are relative. To have potential as a waste reservoir, a rock must be sufficiently porous and permeable to accept a given volume of waste at a given rate. To have potential as a waste-reservoir seal, a rock must be sufficiently low in permeability to either prevent or greatly retard the escape of waste from the reservoir. There are no generally assigned lower-limit values of porosity and permeability requirements for wastestorage reservoirs. There is no generally assigned upper-limit value of the permeability requirement for waste-reservoir seals.

However, in an analogous situation that is somewhat related to waste-storage environments, wherein reservoir rock and reservoir-seal rock constitute an aquifer gas-storage environment that involves a gas-liquid interface rather than a liquidliquid interface, some limiting values for porosity and permeability have been published. Katz and Coats $(1968$, p. 56-57) considered that sandstone with porosity in excess of 10 percent and permeability in excess of 100 millidarcies $(\mathrm{mD})$ is acceptable for gas storage. Katz and Coats $(1968$, p. 11) considered water-saturated caprock, such as shale, with porosity of 2-8 percent and permeability of from $10^{-4}$ to less than $10^{-6}$ millidarcy, to be acceptable for a gas-confining layer. These limiting values for porosity may be compared with the values given by Pettijohn (1957) for the average sandstone, 15-20 percent, and average shale, 13 percent. 
In areas where potential waste-storage reservoirs are present in Units $F, G$, and $H$, the clastic rocks range from unconsolidated and loosely consolidated sand in the upper part of the sediment mass to wellconsolidated sandstone in the more deeply buried parts of the mass. The clastic rocks with reservoirseal potential range from clay and claystone in the upper part of the sediment mass, to their fissile counterpart, shale, in the more deeply buried parts of the mass.

Units F, G, and $H$ have been sparsely tested where they contain saline water. Drill cuttings and a few random cores from only a few wells are available for study. These show that rocks with waste-storage potential in the upper part of the sediment mass are generally unconsolidated sand-clay mixtures, predominantly quartzose, containing illite and montmorillonite. Locally and where indurated, the interstitial cement in these mixtures consists of limonite, siderite, or calcite, and, less commonly, of dolomite or silica. (See Brown and others, 1972, pls. 23-58.)

From evaluation of limited core and geophysicallog data, the average porosity of the sand-clay mixtures is judged to be about 30-35 percent. Permeability values of the sand-clay mixtures, obtained from limited core and pumping-test data, range from less than 0.5 darcy to more than 200 darcies and are judged to average about 30 darcies. In contrast, the porosity and permeability of several sandstone cores, that may be representative of sandstone which occurs in the deeply buried parts of the sediment mass, are relatively low as shown by the core analyses in table 1 . Evidently, the porosity and permeability of potential reservoir rocks decrease with depth of burial. The U.S. Geological Survey's Laboratory, Denver, Colo., provided the core analyses in table 1.

In regional studies of waste-storage potential, the measured thicknesses of sand and shale in well sections may be used indirectly to assess and compare relative-permeability variance in different areas. Thus, the ratio of the unit's potential reservoir sand thickness to the unit's total sand thickness indirectly denotes the relation between usable and available permeability in clastic sections. Also, the ratio of the unit's sand thickness to the unit's shale thickness indirectly denotes the relation between permeability and permeability-barrier potential in clastic sections considered for waste storage. These ratio values, calculated for sections cut in Units F, G, and H, are listed on the well-record sheets and are combined in figures $1 A-C$ and $2 A-C$, respectively.

For any section, the greater the potential reservoir sand thickness relative to total sand thickness, the higher the ratio value and the greater the proportionate thickness of usable permeability in the clastic section. The ratio value is 1 if the total sand thickness comprises usable permeability, and 0.5 if one-half the total sand thickness comprises usable permeability. In figure $1 A-C$, the ratio values, calculated for sections in Units $F, G$, and $H$, are plotted according to number of well occurrences. In most wells where sands are present in Units $F, G$, and $H$,

TABLE 1.-Core analyses for Unit G, Standard Oil of New Jersey, Hatteras Light No. 1, Dare County, N.C. (NC-DA-OT-10)

\begin{tabular}{|c|c|c|c|c|c|c|c|c|c|}
\hline \multirow[t]{2}{*}{ Core description } & \multirow{2}{*}{$\begin{array}{c}\text { Depth } \\
\text { (feet below } \\
\text { mean } \\
\text { sea level) }\end{array}$} & \multirow{2}{*}{$\begin{array}{l}\text { Specific } \\
\text { gravity of } \\
\text { solids }\end{array}$} & \multirow{2}{*}{$\begin{array}{c}\text { Total } \\
\text { porosity } \\
\text { (percent) }\end{array}$} & \multirow{2}{*}{$\begin{array}{l}\text { Effective } \\
\text { porosity }{ }^{1} \\
\text { (percent) }\end{array}$} & \multicolumn{2}{|c|}{$\begin{array}{c}\text { Pore pressures } \\
\text { (psig) }\end{array}$} & \multirow{2}{*}{$\begin{array}{c}\text { Confining } \\
\text { pressure } \\
\text { (psig) }\end{array}$} & \multirow{2}{*}{$\begin{array}{c}\text { Horizontal } \\
\text { hydraulic } \\
\text { conductivity } \\
(\mathrm{m} / \mathrm{d})\end{array}$} & \multirow{2}{*}{$\begin{array}{c}\text { Perme- } \\
\text { ability } \\
\text { (mD) }\end{array}$} \\
\hline & & & & & Input & Output & & & \\
\hline $\begin{array}{l}\text { Limy sandstone. Quartz (65 percent), calcite } \\
\text { (25 percent), sericite (5 percent), chlorite } \\
\text { (2 percent), opaques ( } 2 \text { percent), feldspar } \\
\text { (trace). Subrounded, well-sorted, medium } \\
\text { fine sand grains and mica flakes cemented } \\
\text { together by microcrystalline calcite. A few } \\
\text { calcite fossil fragments, about } 0.5 \text { mm. } \\
\text { Calcite is very dusky with fine inclusions. } \\
\text { Poorly defined preferential orientation of } \\
\text { mica flakes indicate bedding. }\end{array}$ & $7,123-7,133$ & 2.64 & 13.6 & 13.3 & $\begin{array}{l}98 \\
98\end{array}$ & $\begin{array}{l}\text { atm } \\
\text { atm }\end{array}$ & $\begin{array}{l}2,000 \\
2,000\end{array}$ & $\begin{array}{l}3.7 \times 10^{-5} \\
3.5 \times 10^{-5}\end{array}$ & 0.04 \\
\hline $\begin{array}{l}\text { Sandstone. Quartz (93 percent), chlorite ( } \\
\text { percent), feldspar (2 percent), calcite (1 } \\
\text { percent), muscovite (1 percent), opaques (1 } \\
\text { percent). Medium-fine-grained, well-sorted } \\
\text { sandstone. Grains subangular to subrounded. } \\
\text { Grains are very tightly packed; little } \\
\text { apparent porosity. Rock uniform, without } \\
\text { obvious bedding. Sparry calcite in small } \\
\text { patches. }\end{array}$ & $7,326-7,336$ & 2.48 & 15.7 & 11.4 & $\begin{array}{l}108 \\
108\end{array}$ & $\begin{array}{l}\text { atm } \\
\text { atm }\end{array}$ & $\begin{array}{l}1,700 \\
1,700\end{array}$ & $\begin{array}{l}1.1 \times 10^{-0} \\
1.2 \times 10^{-0}\end{array}$ & .12 \\
\hline $\begin{array}{l}\text { Sandstone. Quartz ( } 85 \text { percent), sericite (5 } \\
\text { percent), biotite ( }+ \text { chlorite) (5 percent), } \\
\text { calcite (1-2 percent), opaques (1-2 percent). } \\
\text { Well-sorted, tightly packed rock with mini- } \\
\text { mal pore space. Clay-matrix-grains mostly } \\
\text { in contact. Grains fairly well rounded. Very } \\
\text { faint hint of bedding as shown by slight } \\
\text { preferred orientation of micas. }\end{array}$ & $7,705-7,715$ & 2.61 & 16.5 & 15.8 & $\begin{array}{l}103 \\
103\end{array}$ & $\begin{array}{l}\text { atm } \\
\text { atm }\end{array}$ & $\begin{array}{l}2,000 \\
2,000\end{array}$ & $\begin{array}{l}1.1 \times 10^{-4} \\
1.0 \times 10^{-4}\end{array}$ & .18 \\
\hline
\end{tabular}

1 Effectve porosity for pores having entrance diameters larger than 0.1 micron. 


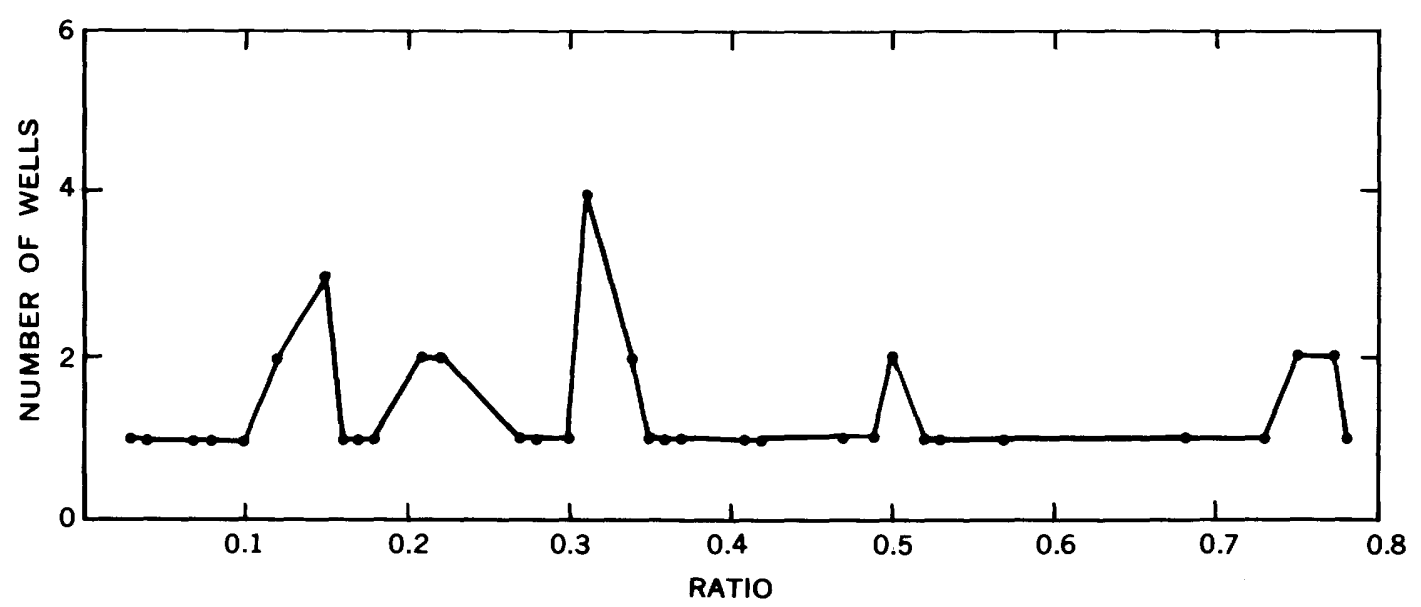

A. UNIT F (45 WELLS)

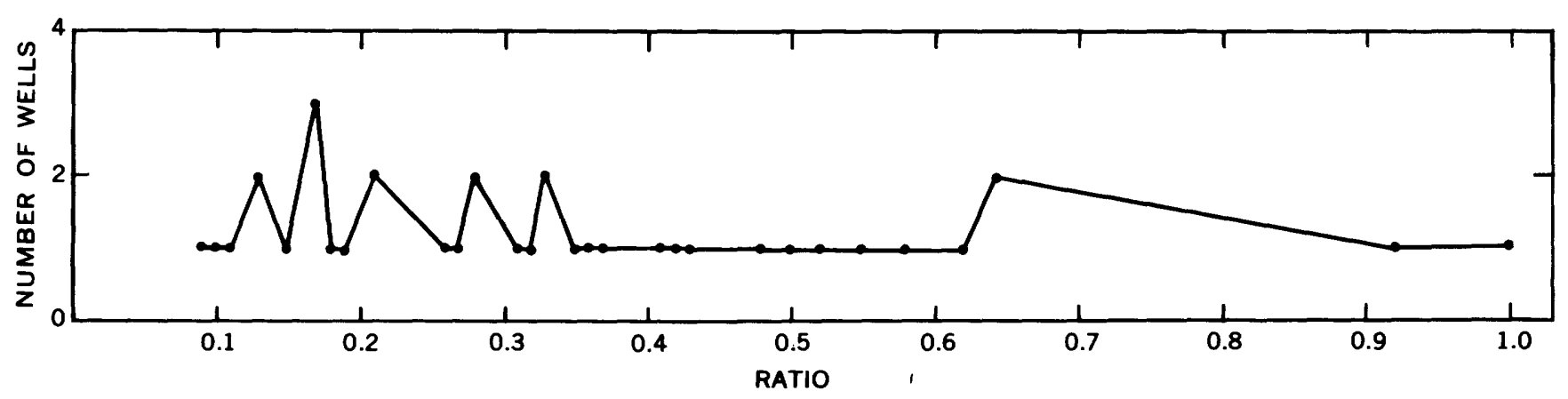

B. UNIT G (37 WELLS)

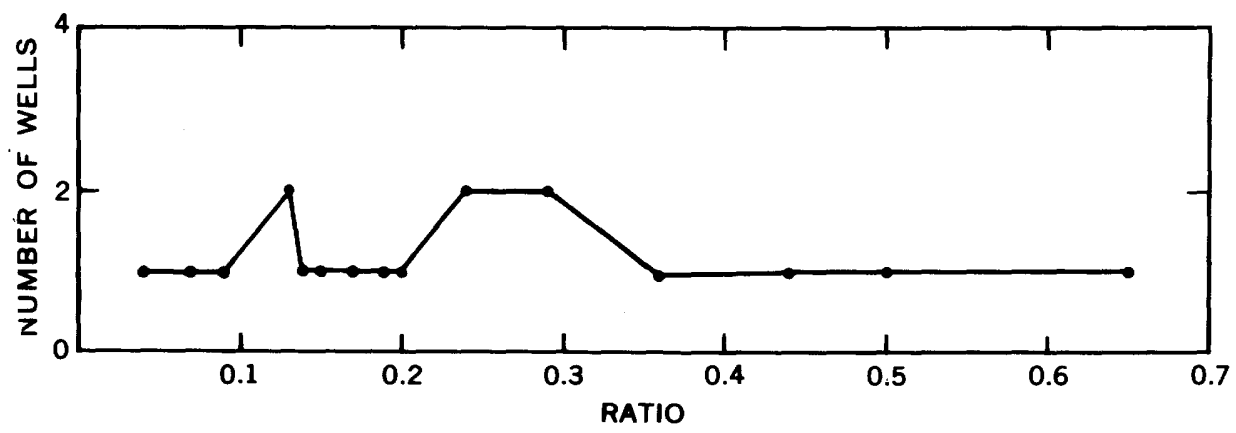

C. UNIT H (18 WELLS)

FigURE 1.-Ratio of the unit's potential waste-reservoir sand thickness to unit's total sand thickness. $A$, Unit F. $B$, Unit G. $C$, Unit $\mathrm{H}$.

Unit $\mathrm{G}$ has the greatest and Unit $\mathrm{H}$ has the least proportionate thickness of usable sand permeability for waste storage.

For any section, the greater the thickness of shale, relative to the thickness of sand, the lower the sandshale ratio value and the greater the proportionate thickness of potential permeability-barrier zones in the section. For a section composed of half sand and half shale, the ratio value is 1 and the total thickness of permeability and permeability-barrier zones in sections considered for waste storage is equal. In Figure $2 A-C$, the ratio values, calculated for sections in Units $F, G$, and $H$, are plotted according to percentage of wells. For all the sections cut in Units $F, G$, and $H$, the permeability-barrier potential is greatest in Unit G's average section. 


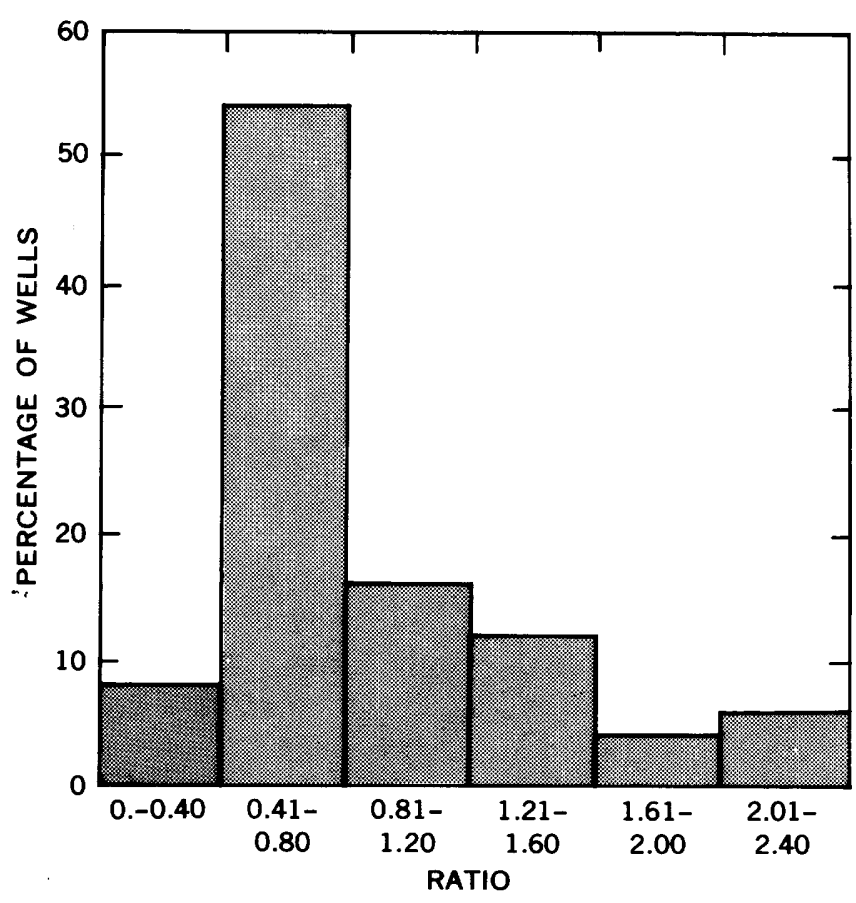

A. UNIT F (50 WELLS)

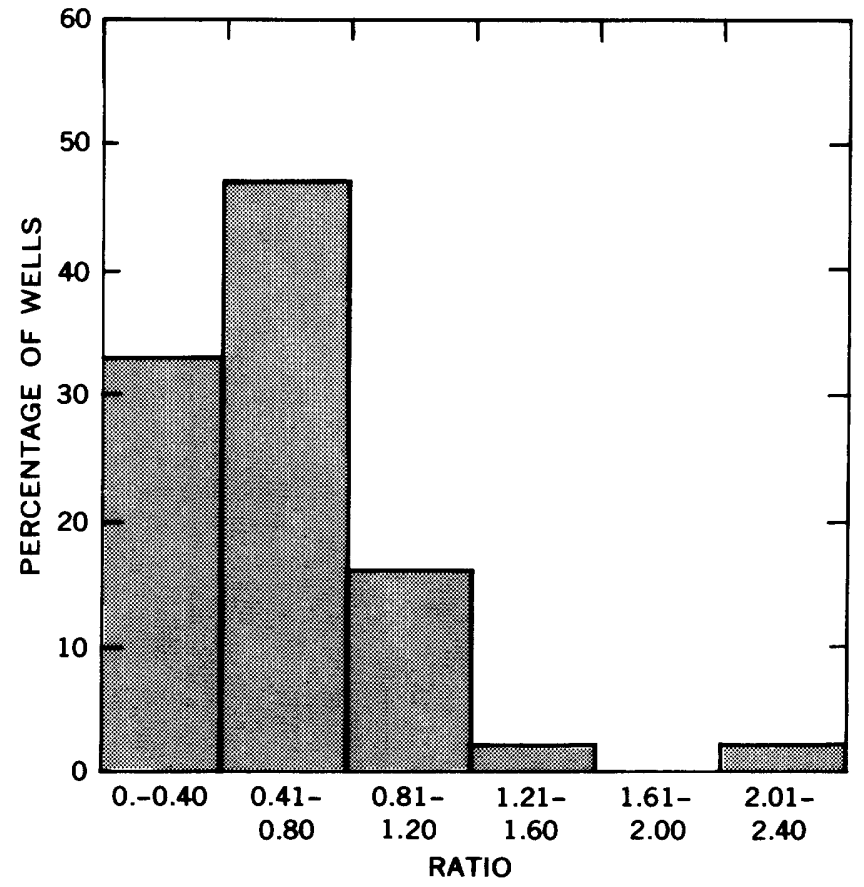

B. UNIT G (43 WELLS)

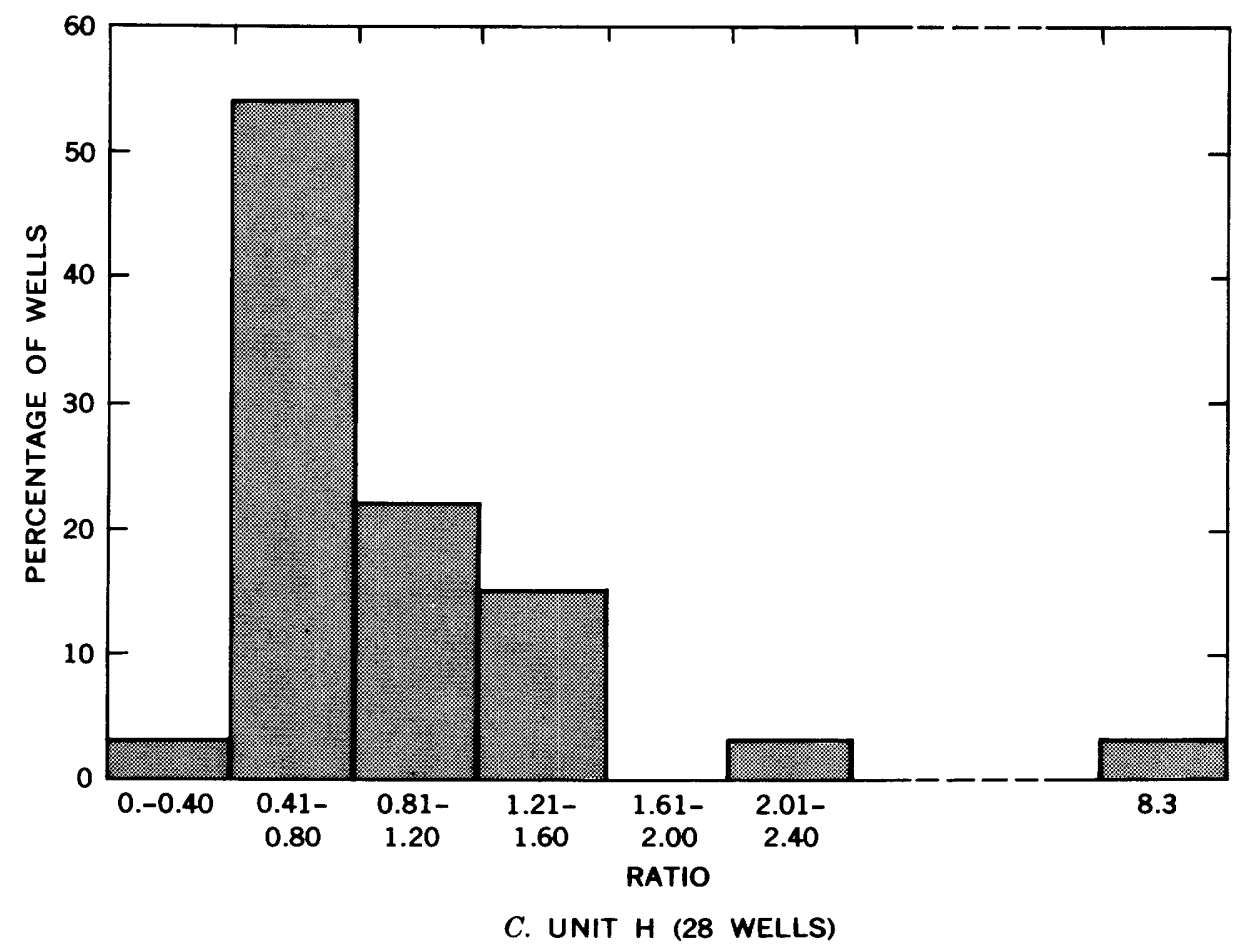

FIGURE 2.-Ratio of the unit's sand thickness to unit's shale thickness. $A$, Unit F. $B$, Unit G. $C$, Unit H. 
Further generalization of the distribution of permeability in Units $\mathrm{F}, \mathrm{G}$, and $\mathrm{H}$ is not warranted from the available data.

\section{DISCUSSION AND ANALYSIS OF MAPS AND CHARTS}

Each waste-storage situation has its own geologic requirements and each potential waste-storage environment has its own local geology. Assessment of waste-storage potential must be made within a costrisk-benefit framework. The assessment necessitates establishment of a mutually satisfying relation between the variable geologic requirements for waste storage and the variable geologic parameters of potential waste-storage environments.

Except in an individual case, the geologic requirements for waste storage cannot be predefined quantitatively, in terms of either minimum or optimum values of geologic parameters that may be used to delineate potential waste-storage environments. These parameters would include the depth of burial of an environment and the thickness and areal extent of its reservoir and reservoir-seal components. Also, within the cost-risk-benefit framework it is not possible to prejudge, positively or negatively, the relative importance that might be placed on any one geologic parameter for a waste-storage situation that might arise in the future. For example, the depth of burial of a potential waste-storage reservoir might constitute a prohibitive cost factor in one situation, whereas it might constitute a desirable safety factor in another situation. Similar correspondence may be established with respect to other geologic or geologically derived parameters inherent in the potential waste-storage environment and the relation they bear to geologic requirements for waste storage.

It is necessary to establish a mutually satisfying relation between the geologic requirements for waste storage and the geologic parameters of potential waste-storage environments. Since the geologic requirements for waste storage cannot be defined quantitatively, except perhaps in an individual case, it is appropriate to establish a quantitative range of values for the geologic parameters of the environments.

The selection of a set of geologic parameters having a range of values to show the distribution of potential waste-reservoir environments is based on an assessment of many physical-economic factors, but is dictated by the subsurface data that are available. In order to have waste-storage utility, the geo- logic parameters selected and as already given and the range of values established for them must be capable of providing for geologic definition in different waste-storage situations, most of which are not yet fully known.

For each of the three regional chronostratigraphic units (Units $F, G$, and $H$ ) judged to have wastestorage potential, six geohydrologic maps and five graphs were constructed, using the basic data tabulated on the well-data sheets for wells that comprise the key-well network. The maps and graphs depict a range of values for various combinations of geologic parameters that may be considered in assessing waste-storage potential. For any one unit, the maps and graphs should be considered collectively in assessing the unit's waste-storage potential. The maps and graphs for all three units may be considered in various combinations in a comparative or interunit assessment of waste-storage potential.

In a companion report (Brown and others, 1972) the external and internal geometry of Units F, G, and $\mathrm{H}$ was described and discussed in terms of the structural and tectonic events that controlled the sedimentary processes of deposition and erosion. That material supplements the brief interpretive analysis of the following maps and graphs constructed for each geologic unit in this report.

\section{WASTE-STORAGE POTENTIAL OF GEOLOGIC UNITS \\ UNIT H-ROCKS OF CRETACEOUS AND LATE JURASSIC(?) AGE}

The designated type-reference section for Unit $\mathrm{H}$ (Brown and others, 1972, p. 38, pl. 50) is a well section, 1,120 feet thick, in Pamlico Sound, Hyde County, N.C. (NC-HY-OT-11, pl. 1, Record No. 1151). The maximum thickness measured, 2,072 feet, is in a well in Worcester County, Md. (MD-WOR-OT-11, pl. 1, Record No. 3034).

In the area where the unit is judged to have waste-storage potential ( $\mathrm{pl} .2$ ), its total thickness ranges from less than 100 to more than 2,200 feet, and its total sand thickness ranges from zero to more than 1,300 feet (pl. 2). The maximum sand thickness measured, 1,206 feet, is in a well in Cape May County, N.J. (NJ-CM-OT-1, pl. 1, Record No. 5000). For 31 wells in which Unit $H$ is present, the percentage thickness of sand in a given section ranges from zero (NC-PAM-OT-9, pl. 1, Record No. 1122) to 100 (NC-CAR-OT-8, pl. 1, Record No. 1080) and averages 40. Thus, on the basis of 
available well data, 40 percent of any clastic section that represents a complete thickness of Unit $\mathrm{H}$ might be expected to have some degree of storage potential.

The number of potential waste-storage reservoirs present in Unit $\mathrm{H}$ varies with location. Although layers of sand 20 feet or more in thickness are common in the unit, there is a deficiency of shale layers, 20 feet or more in thickness, in many sections cut through Unit $H$. In general, the absence of reservoirs in Unit $\mathrm{H}$ may be attributed to the absence of a required thickness of overlying or underlying shale rather than to the absence of a required thickness of sand.

The number of potential waste-reservoir sands that are present in Unit $\mathrm{H}$, per well, is shown in figure $3 C$. No potential reservoir sands are present in 13 wells, or 41 percent of the wells in which the unit occurs. The maximum number of potential reservoir sands recognized in the unit, seven, are present in two wells (MD-WIC-OT-11, pl. 1, Record No. 3032 and MD-WOR-OT-10, pl. 1, Record No. $3033)$. In wells that comprise the key-well network and in which potential reservoir sands are present, one sand occurs more frequently than any other number.

The thickness of individual reservoir sands present in Unit $\mathrm{H}$ ranges from 20 feet (NC-CAR-OT12, pl. 1, Record No. 1085) to 85 feet (MD-WOROT-10, pl. 1, Record No. 3033) and averages 35 feet. However, for the greatest number of wells in which Unit $\mathrm{H}$ is present and as shown in figure $4 C$, the maximum thickness of a potential reservoir sand is 20-29 feet. On the basis of available data (figs. $3 C$ and $4 C$ ), an average of one or two reservoir sands, with each sand having a thickness of $\mathbf{3 5}$ feet, could be expected to occur in Unit $\mathrm{H}$ in areas where it is judged to have waste-storage potential.

In the individual wells in which Unit $\mathrm{H}$ is present, the total thickness of the unit's potential reservoir sand ranges from 20 feet (NC-CAR-OT-12, pl. 1, Record No. 1085) to 339 feet (MD-WOR-OT-10, pl. 1, Record No. 3033) and average 83 feet. Plate 3 is a regional map that shows the distribution of a range of values for the total thickness of potential waste-reservoir sand in Unit $\mathrm{H}$. In general, the total thickness of such sand is greater beneath parts of Sussex County, Del., and beneath all or parts of Caroline, Dorchester, Talbot, Wicomico, and Worcester Counties, Md.

Plate 2 is a regional map on which the averaged depth to the top of the unit's potential waste-reser- voir sands is shown by contours. Basic data used to construct the map were calculated for individual wells and are listed in the well-record sheets. For Unit $H$, this range in depth below sea level is from about 1,800 feet in York and Gloucester Counties, Va., to about 8,500 feet in the vicinity of Cape Hatteras, Dare County, N.C.

Data that supplement those presented on plate 2 are shown in figure $5 C$. In the 18 wells for which data are available, 26 percent of the unit's potential waste-reservoir sand occurs in its upper third, 39 percent in its middle third, and 35 percent in its lower third. These percentage values suggest that the middle third of the unit has the greatest wastestorage potential and the upper third the least potential.

For Unit H, the Depth/Potential Reservoir factor (feet of overburden per foot of potential wastereservoir sand) ranges in value from a low of $\mathbf{1 5}$ (MD-WIC-OT-11, pl. 1, Record No. 3032) to a high of 429 (NC-DA-OT-10, pl. 1, Record No. 1153). Plate 4 is a regional map that shows the distribution and a range of values for the $D / P R$ factor in the area where Unit $\mathrm{H}$ has waste-storage potential. Basic data used to construct the map were calculated for individual wells and are listed in the well-record sheets. As indicated by the spatial distribution of the values on the map, a $D / P R$ factor with a value $>100$ is dominant within Unit $H$.

As defined in this report, a potential waste-storage environment consists of a relatively permeable reservoir sand, or sandstone, in direct contact, above and below, with a relatively impermeable clay or shale that serves as a reservoir seal. The reservoir-sealing capability of the shale depends, in part, on its total thickness and, in part, on its thickness relative to the thickness of the reservoir sand with which it is in contact. A total thickness for the shale that is in contact, above and below, with each reservoir sand delineated in Unit $\mathrm{H}$ is listed on the well-record sheets, together with a calculated thickness for feet of shale per foot of reservoir sand.

In the area where Unit $\mathrm{H}$ has waste-storage potential, a maximum thickness of 135 feet is recorded for a shale seal that immediately overlies a reservoir sand (NC-CUR-OT-13, pl. 1, Record No. 1250), and the maximum value calculated for the thickness of a shale seal per foot of underlying reservoir sand is about 6.8 feet in the same well. Within the potential waste-reservoir environments present in Unit $\mathrm{H}$, the average thickness of overlying shale seals is about 41.6 feet and the average value for the 


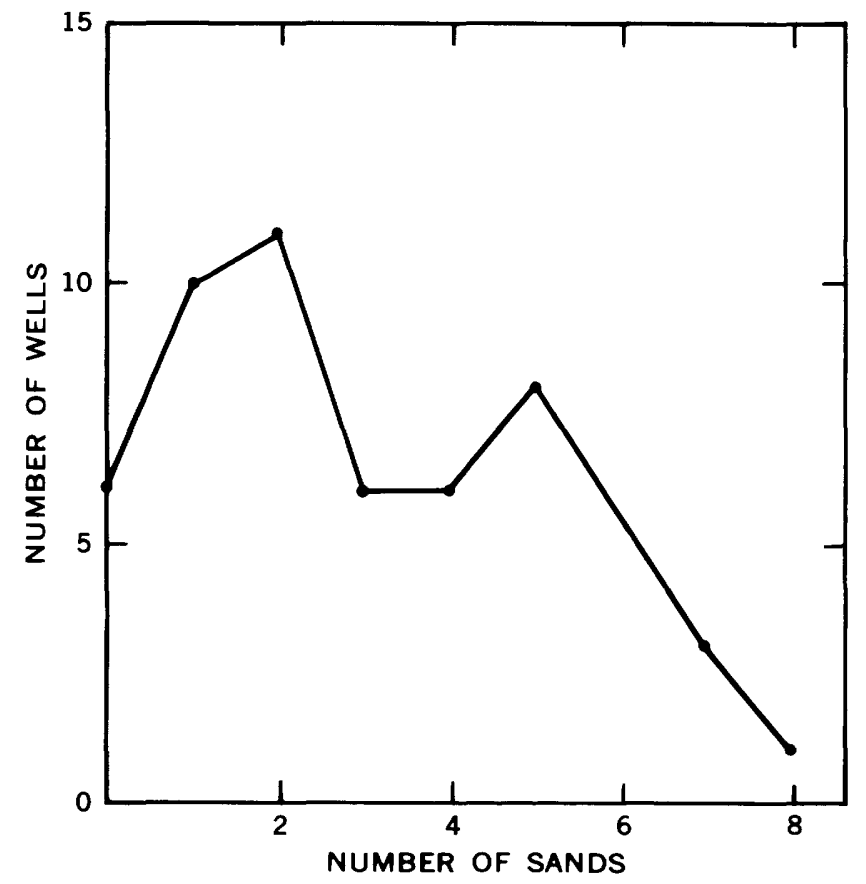

$A$. UNIT F (51 WELLS)

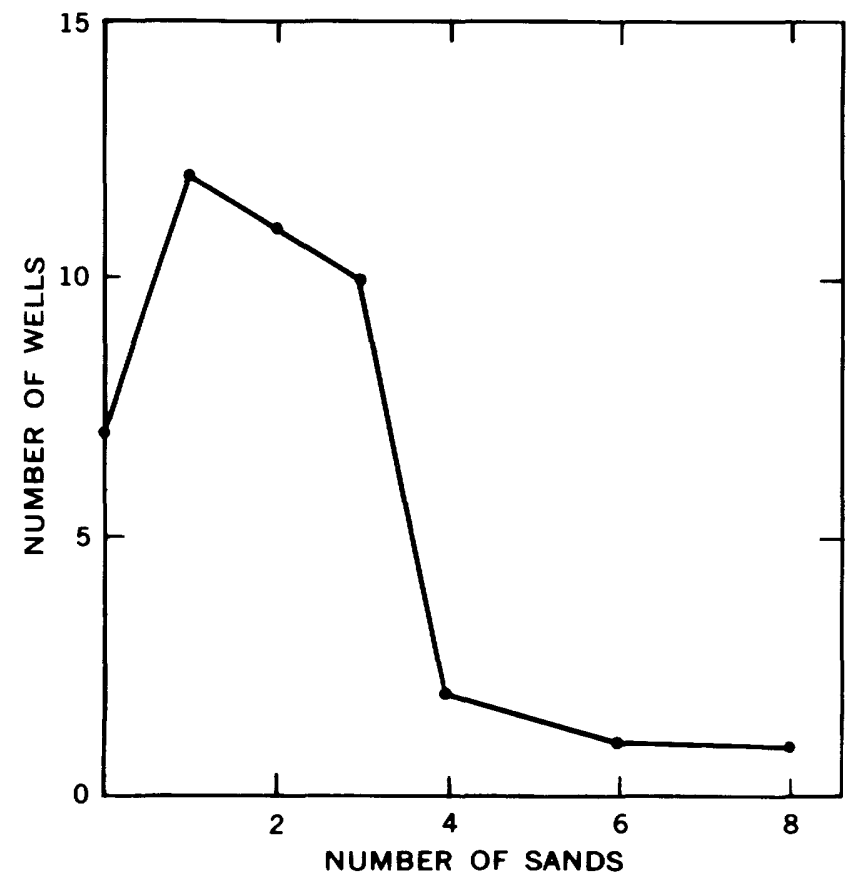

B. UNIT G (44 WELLS)

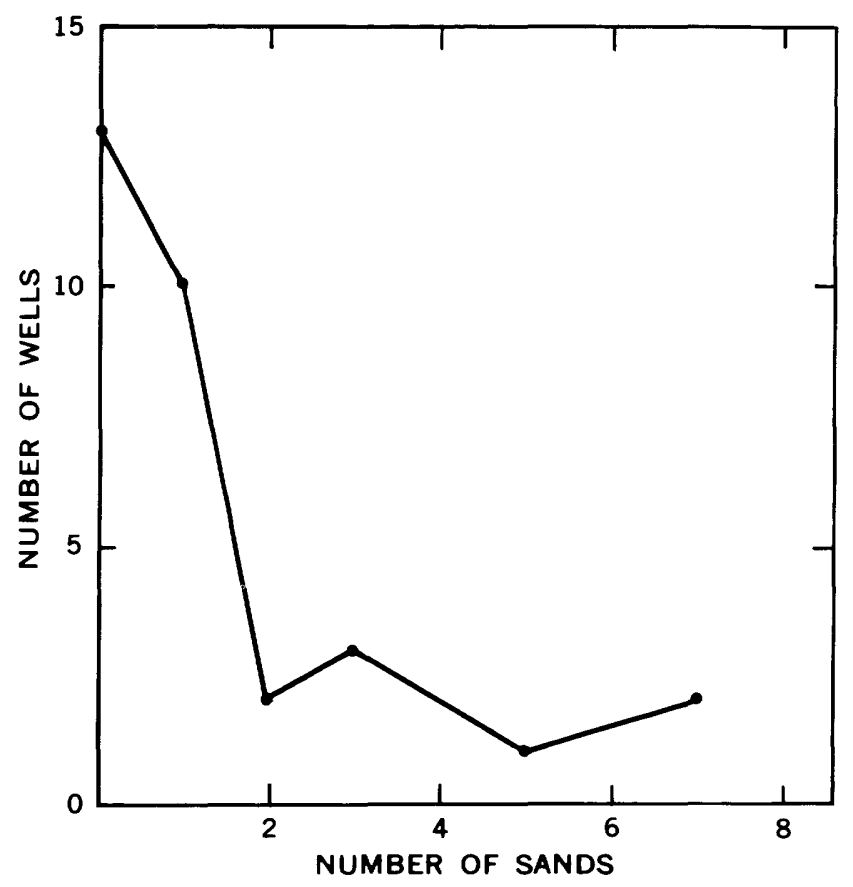

C. UNIT H (31 WELLS)

FIGURE 3.-Number of potential waste-reservoir sands occurring per well. $A$, Unit F. $B$, Unit G. $C$, Unit H. 


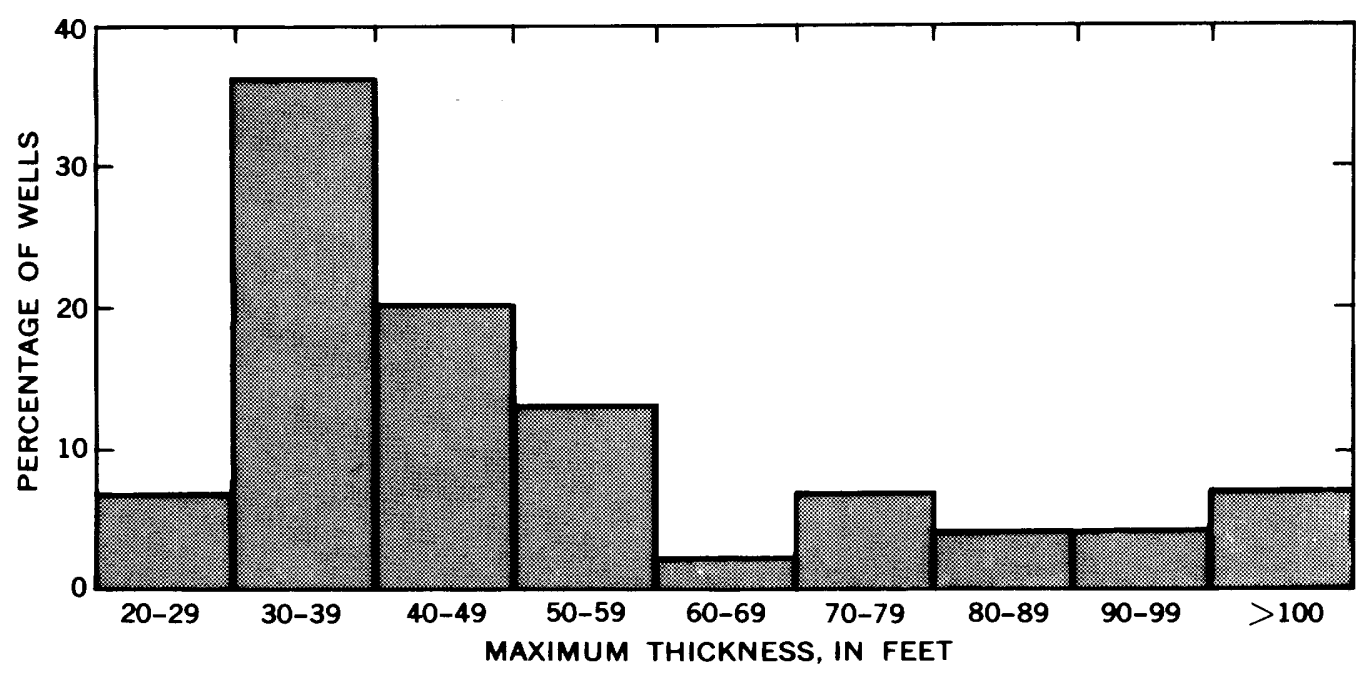

A. UNIT F (45 WELLS)

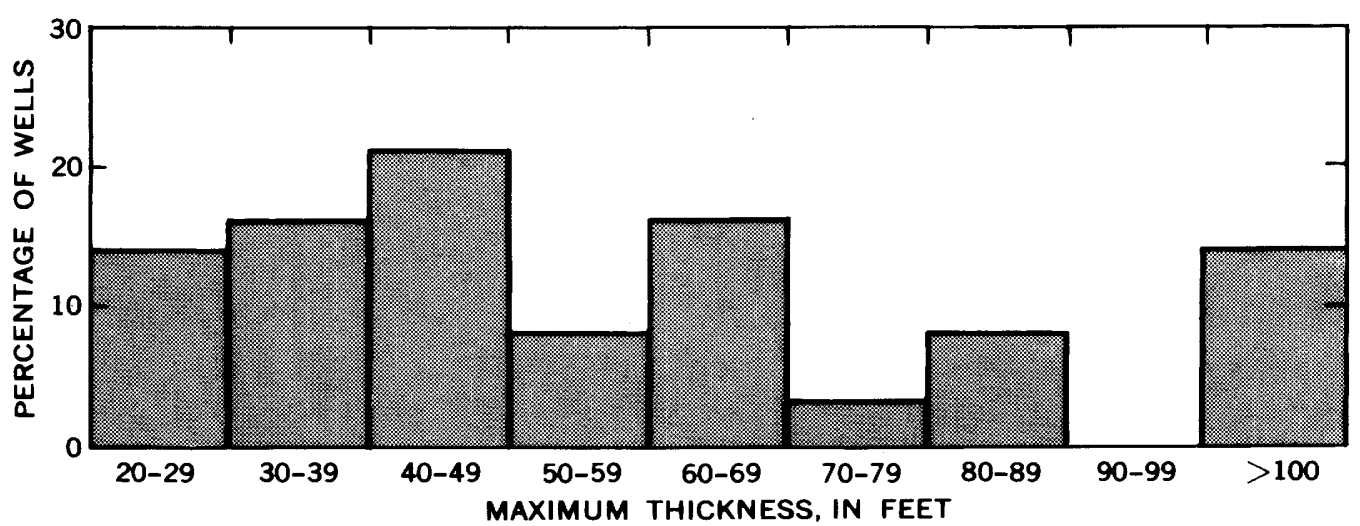

B. UNIT G (37 WELLS)

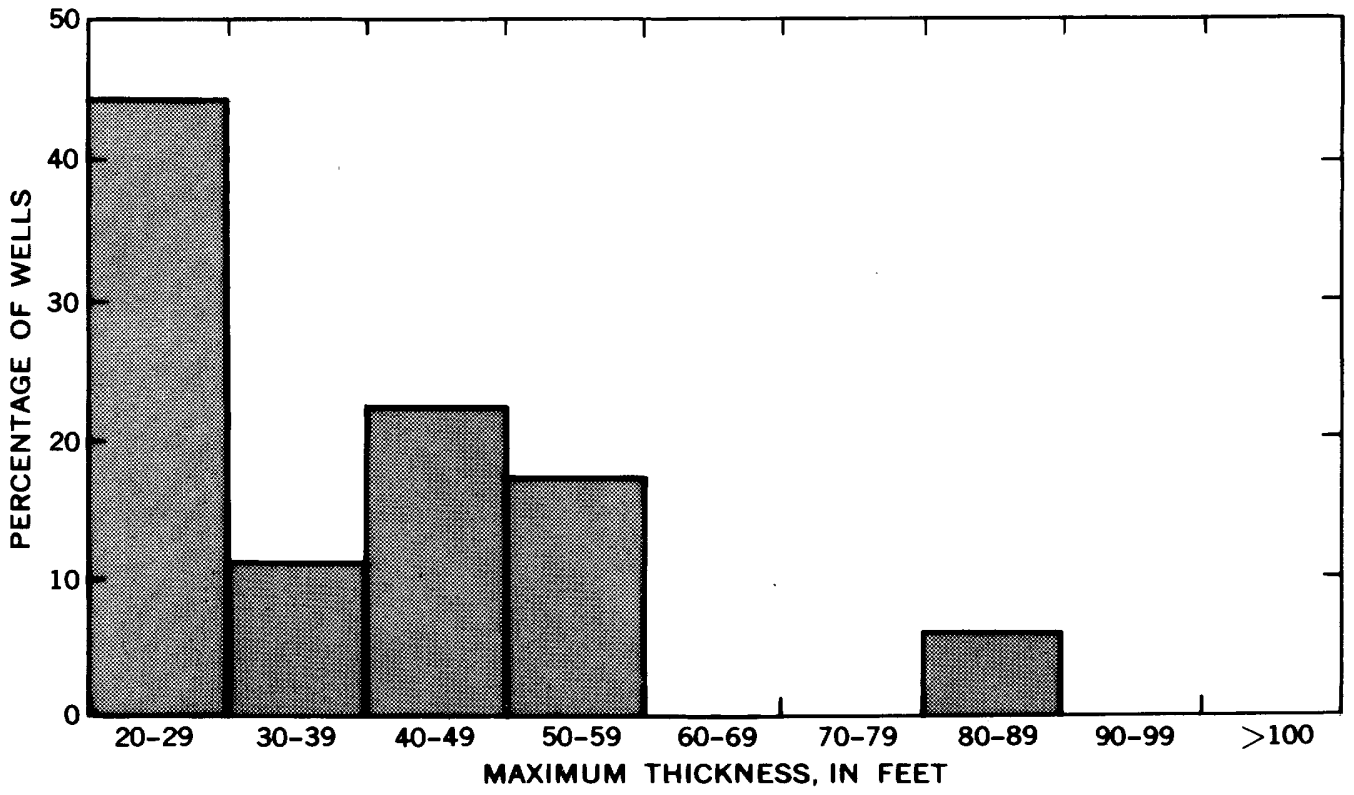

C. UNIT H (18 WELLS)

FIGURE 4.-Maximum thickness of potential waste-reservoir sands, according to percentage of wells. $A$, Unit F. $B$, Unit G. $C$, Unit $\mathbf{H}$. 


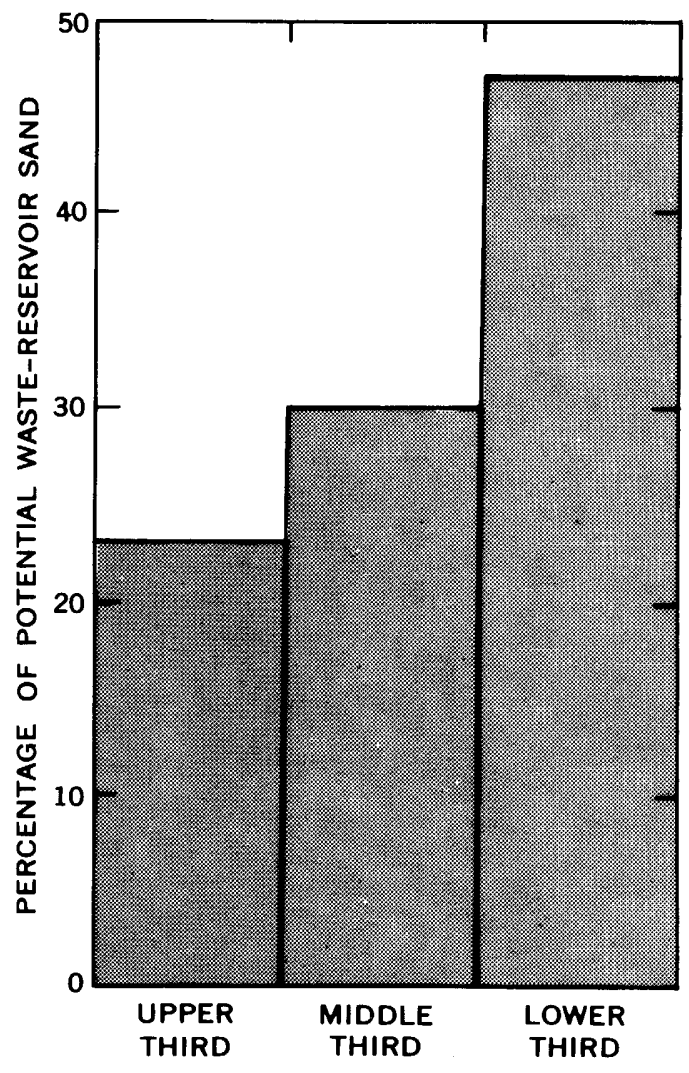

A. UNIT F (45 WELLS)

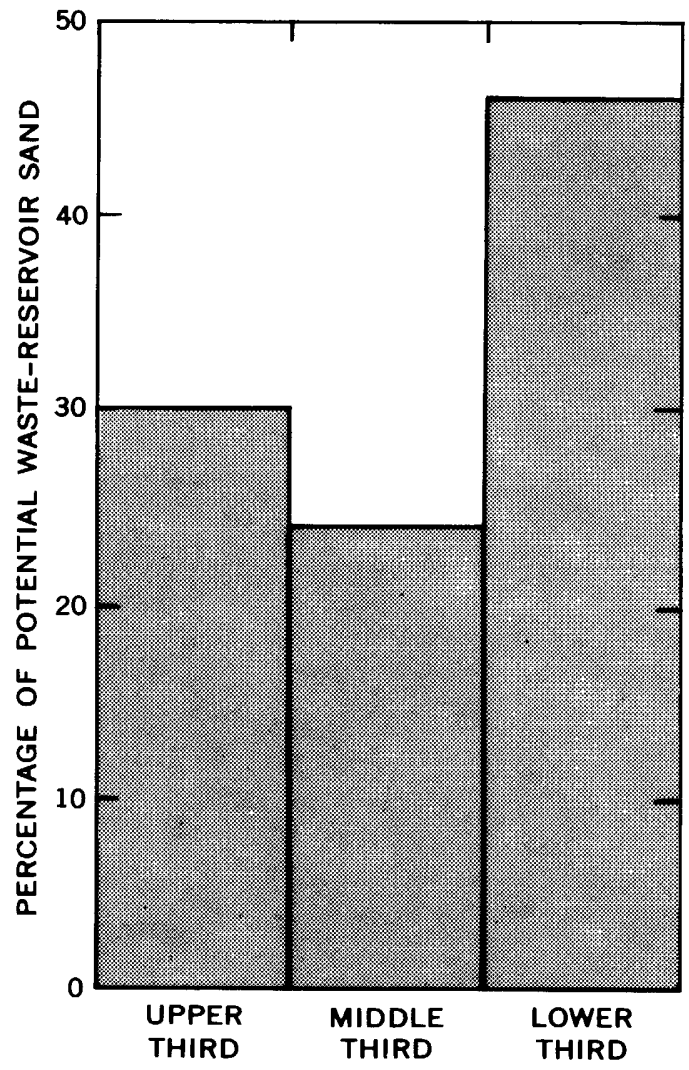

B. UNIT G (37 WELLS)

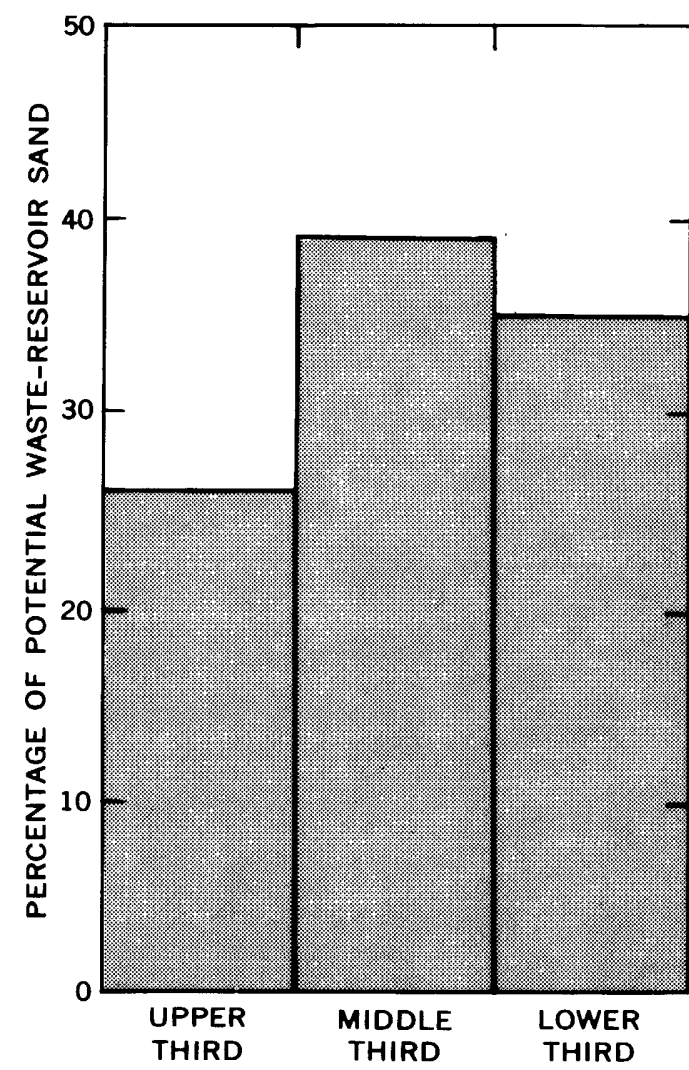

C. UNIT H (18 WELLS)

FIGURE 5.-Occurrence of potential waste-reservoir sands in percent, in upper third, middle third, and lower third of unit, according to percent well occurrence. $A$, Unit F. $B$, Unit G. $C$, Unit $\mathrm{H}$. 
calculated thickness of these shale seals per foot of reservoir sand is about 1.2 feet. Plate 3 is a regional map that shows the distribution of the averaged thickness (feet) per foot of potential wastereservoir sand for the shale seals that immediately overlie the reservoir sands in Unit $\mathrm{H}$. The scale of values ranges from less than 1 to more than 3 feet. The relative areal extent indicates that the dominant thickness is from 1.0 to 2.0 feet of shale per foot of reservoir sand. A maximum thickness of 95 feet is recorded for a shale seal that immediately underlies a reservoir sand (MD-WOR-OT-11, pl. 1, Record No. 3034), and the maximum value calculated for the thickness of a shale seal per foot of overlying reservoir sand is about 3.5 feet (NC-CUR-OT-12, pl. 1, Record No. 1240). In Unit H's potential wastestorage environments, the average thickness of underlying shale seals is about 38 feet and the average value for the calculated thickness of these shale seals per foot of reservoir sand is about 1.1 feet. Plate 4 is a regional map that shows the distribution of the averaged thickness (feet) per foot of potential reservoir sand for the shale seals that immediately underlie the reservoir sands in Unit $\mathrm{H}$. The scale of values ranges from less than 1 to more than 3 feet. The dominant thickness is the one ranging from 1.0 to 2.0 feet of shale per foot of reservoir sand.

A summary of the data for Unit $\mathrm{H}$ is listed in table 2.

\section{UNIT G-ROCKS OF GRETAGEOUS AGE}

The designated type-reference section for Unit $\mathrm{G}$ (Brown and others, 1972, p. 39, pl. 50) is a well section, 942 feet thick, in Carteret County, N.C. (NC-CAR-0T-5, pl. 1, Record No. 1090). The maximum thickness measured, 1,720 feet, is in a well in Pamlico Sound, Dare County, N.C. (NC-DAOT-12, pl. 1, Record No. 1152).

In areas where Unit $G$ is judged to have waste- storage potential (pl. 5), its total thickness ranges from less than 100 to more than 1,800 feet, and its total sand thickness ranges from less than 100 to about 685 feet (pl. 5). The maximum total sand thickness measured, 685 feet, is in a well in Dare County, N.C. (NC-DA-OT-10, pl. 1, Record No. 1153). In well sections in Unit $G$, the total proportionate thickness of sand occurring in any one section ranges from 17 percent (NJ-CU-OT-8, pl. 1, Record No. 5010) to 61 percent (NC-GA-OT-15, pl. 1, Record No. 1251) and averages 33 percent. Thus, based on available well data, 33 percent of any clastic section representing a complete thickness of Unit $G$ might be expected to have some degree of storage potential.

The number of potential waste-storage reservoirs present in Unit $G$ varies with location. In general, the absence of these reservoirs in Unit G, may be attributed to the absence of a required thickness of sand in the section rather than to the absence of required thicknesses of shale. The number of potential reservoir sands that occur in Unit G, per well, is shown in figure $3 B$. The unit contained no potential reservoir sands in seven wells, or 19 percent of the wells in which the unit is present. The maximum number of potential-reservoir sands recognized in Unit G, eight, occurs in only one well (NC-DA-OT11 , pl. 1, Record No. 1193). In wells that comprise the key-well network and in which potential reservoir sands are present, one sand occurs more frequently than any other number.

The thickness of individual reservoir sands present in Unit $\mathrm{G}$ ranges from 20 feet in several wells (NC-CAR-OT-12, pl. 1, Record No. 1085) to 165 feet (NC-DA-OT-12, pl. 1, Record No. 1152) and averages 43 feet. However, for the greatest number of wells in which Unit $G$ is present and as shown in figure $4 B$, the maximum thickness of a potential reservoir sand is $40-49$ feet. On the basis of available data (figures $3 B$ and $4 B$ ), an average of two

TABLE 2.-Summary of selected waste-storage data, Units $F, G$, and $H$

\begin{tabular}{|c|c|c|c|}
\hline $\begin{array}{l}\text { Basic geologic-data elements associated with the waste-storage } \\
\text { potential of Units } F, G \text {, and } H\end{array}$ & Unit $F$ & Unit G & Unit $\mathbf{H}$ \\
\hline 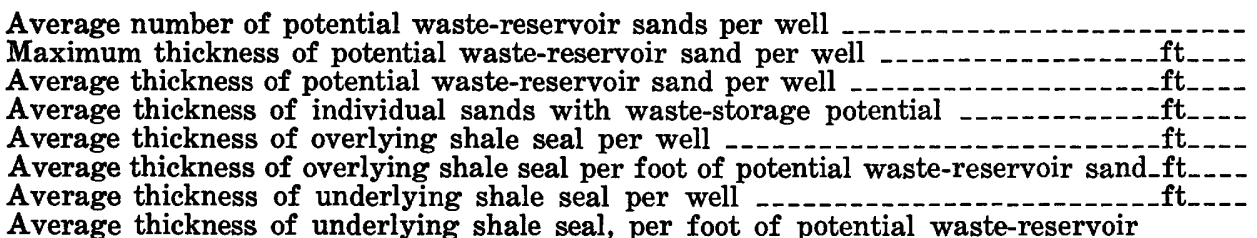 & $\begin{array}{c}2.8 \\
185 \\
122 \\
52 \\
48.8 \\
1.3 \\
47.3\end{array}$ & $\begin{array}{c}2.0 \\
295 \\
100 \\
57 \\
62.9 \\
1.5 \\
57.1\end{array}$ & $\begin{array}{r}1.4 \\
339 \\
83 \\
37 \\
41.6 \\
1.2 \\
38.1\end{array}$ \\
\hline Range for the average depth of unit's potential waste-reservoir sands & $\begin{array}{l}1.2 \\
>1800 \text { to } \\
>8500\end{array}$ & $\begin{array}{l}1.3 \\
<1700 \text { to } \\
>7000\end{array}$ & $\begin{array}{l}1.1 \\
<1600 \text { to } \\
>5900\end{array}$ \\
\hline $\begin{array}{l}\text { Range in value for unit's } D / P R \text { factor (feet of overburden per foot of potential } \\
\text { waste-reservoir sand) }\end{array}$ & $15-429$ & $15-147$ & $7-291$ \\
\hline
\end{tabular}


reservoir sands, each sand having a thickness of 43 feet, could be expected to occur in Unit $G$ in areas where it has waste-storage potential.

In the 37 individual wells in which Unit $G$ is present, the total thickness of the unit's potential reservoir sand ranges from 20 feet in several wells (see, NC-CAM-OT-10, pl. 1, Record No. 1234) to 295 feet (NC-DA-OT-10, pl. 1, Record No. 1153) and averages 100 feet. Plate 6 is a regional map showing the distribution of the total thickness of potential waste-reservoir sand in Unit G. In general, the total thickness of such sand is greatest beneath parts of Pamlico Sound, N.C.

Plate 5 is a regional map on which the averaged depth to the top of the unit's potential waste-reservoir sands is shown by contours. Basic data used to construct the map were calculated for individual wells and are listed on the well-record sheets. For Unit G, this range in depth below sea level is from about 1,700 feet in Chesapeake Bay, adjacent to Mathews County, Va., to about 7,000 feet in Dare County, N.C.

Data that supplement those presented on plate 5 are shown in figure $5 B$. In the 37 wells for which data are available, 30 percent of the unit's potential reservoir sand occurs in its upper third, 24 percent in its middle third, and 46 percent in its lower third. These percentage values suggest that the lower third of the unit has the greatest waste-storage potential and the middle third the least such potential.

For Unit G, the Depth/Potential Reservoir factor (feet of overburden per foot of potential wastereservoir sand) ranges in value from 15 (NC-DAOT-11, pl. 1, Record No. 1193) to 147 (NC-TYOT-4, pl. 1, Record No. 1371). Plate 7 is a regional map showing the distribution and a range of values for the $D / P R$ factor in the area where Unit $G$ has waste-storage potential. As indicated by the relative areal extent of the values on the map, a $D / P R$ factor of less than 20 is dominant within Unit G.

A total thickness for the shale that immediately overlies and underlies each potential reservoir sand delineated in Unit $G$ is listed on the well-record sheets, together with a value for the calculated thickness (feet) of shale per foot of reservoir sand.

In areas where Unit $\mathrm{G}$ is judged to have wastestorage potential, a maximum thickness of 350 feet is recorded for a shale that immediately overlies a reservoir sand (NC-CUR-OT-12, pl. 1, Record No. 1240 ), and the maximum value calculated for the thickness of a shale seal per foot of reservoir sand is about 11.7 feet in the same well. Within the potential waste-storage environments present in Unit $\mathrm{G}$, the average thickness of overlying shale seals is about 62.9 feet and the average calculated thickness of these shale seals per foot of reservoir sand is about 1.5 feet. Plate 6 is a regional map that delineates the distribution of the averaged thickness (feet) per foot of potential reservoir sand for the shale seals that immediately overlie the reservoir sands in Unit G. The scale of values ranges from less than 1 to more than 3 feet. The relative areal extent of the values mapped indicates that the dominant thickness is from 1.0 to 2.0 feet of shale per foot of reservoir sand.

A maximum value of 350 feet is recorded for a shale seal that immediately underlies a reservoir sand (NC-CUR-OT-12, pl. 1, Record No. 1240), and the maximum value calculated for the thickness of a shale seal per foot of overlying reservoir sand is about 7.8 feet in the same well. For Unit G's potential waste-storage reservoirs, the average thickness of underlying shale seals is about 57.1 feet, and the average value for the calculated thickness of these shale seals per foot of reservoir sand is about 1.3 feet. Plate 7 is a regional map on which a distribution of the averaged thickness (feet) per foot of potential reservoir sand, for the shale seals that immediately underlie the reservoir sands in Unit G is shown by means of patterns for values ranging from less than 1 to more than 3 feet. As indicated by the relative areal extent of the value patterns mapped, the dominant pattern is one ranging from 1.0 to 2.0 feet of shale per foot of reservoir sand.

A summary of the data for Unit $G$ is listed on table 2.

\section{UNIT F-ROCKS OF CRETACEOUS AGE}

The designated type-reference section for Unit $\mathrm{F}$ (Brown and others, 1972, p. 40, pl. 43) is a well section, 83 feet thick, in Halifax County, N.C. (NCHAL-T-2, pl. 1, Record No. 1197). The maximum thickness measured, 1,267 feet, is in a well in Worcester County, Md. (MD-WOR-OT-10, pl. 1, Record No. 3033).

In areas where Unit $\mathrm{F}$ is judged to have wastestorage potential (pl. 8), its total thickness ranges from less than 300 to more than 1,200 feet, and its total sand thickness ranges from less than 100 to more than 800 feet (pl. 8). The maximum total sand thickness measured, 876 feet, is in a well in Dare County, N.C. (NC-TY-OT-3, pl. 1, Record No. $1370)$. In well sections in Unit $F$, the total propor- 
tionate thickness of sand occurring in any one section ranges from about 20 percent (MD-QA-T-15, pl. 1, Record No. 3129) to 94 percent (NC-TY-OT3 , pl. 1, Record No. 1370) and averages 43 percent. Thus, on the basis of available well data, 43 percent of any clastic section representing a complete thickness of Unit F might be expected to have some degree of storage potential.

The number of potential waste-storage reservoirs present in Unit $\mathrm{F}$ varies with location. In general, the absence of these reservoirs in Unit $F$ may be attributed to the absence of a required thickness of overlying or underlying shale rather than to the absence of a required thickness of sand. The number of potential reservoir sands that occur in Unit $F$, per well, is shown in figure $3 A$. The unit contained no potential reservoir sands in five wells, or 11 percent of the wells in which the unit is present. The maximum number of potential-reservoir sands recognized in Unit F, eight, occurs in only one well (MD-WOR-OT-10, pl. 1, Record No. 3033). In wells that comprise the key-well network and in which potential reservoir sands are present, two sands occur more frequently than any other number.

The thickness of individual reservoir sands in Unit $F$ ranges from 20 feet in several wells (see, NC-DA-OT-10, pl. 1, Record No. 1153) to 185 feet (MD-WOR-OT-11, pl. 1, Record No. 3034) and averages 38 feet. However, for the greatest number of wells in which Unit $F$ is present and as shown in figure $4 A$, the maximum thickness of a potentialreservoir sand is 30-39 feet. On the basis of available data (figures $3 A$ and $4 A$ ), an average of about three reservoir sands, each sand having a thickness of 38 feet, could be expected to occur in Unit F in areas where it has waste-storage potential.

In the 45 individual wells in which Unit $F$ is present, the total thickness of the unit's potentialreservoir sand ranges from 20 feet (NC-DA-OT-10, pl. 1, Record No. 1153) to 510 feet (NC-HY-OT11, pl. 1, Record No. 1151) and averages 122 feet. Plate 9 is a regional map showing the distribution of the total thickness of potential waste-reservoir sand in Unit F. In general, the total thickness of such sand is greater beneath parts of Pamlico Sound and contiguous areas in North Carolina and beneath parts of Worcester County, Md., and Sussex County, Del.

Plate 8 is a regional map on which the averaged depth to the top of the unit's potential waste-reservoir sands is shown by contours. Basic data used to construct the map were calculated for individual wells and are listed on the well-record sheets. For Unit $\mathrm{F}$, this range in depth below sea level is from about 1,600 feet in Kent County, Del., to about 5,900 feet in Dare County, N.C.

Data that supplement those presented on plate 8 are shown in figure $5 \mathrm{~A}$. In the 45 wells for which data are available, 23 percent of the unit's potential waste-reservoir sand occurs in its upper third, 30 percent in its middle third, and 47 percent in its lower third. Assuming uniform porosity and permeability, these percentage values suggest that the lower third of the unit has the greatest waste-storage potential and the upper third the least such potential for a given unit thickness.

For Unit F, the Depth/Potential Reservoir factor (feet of overburden per foot of potential wastereservoir sand) ranges in value from 7 (MD-WOROT-11, pl. 1, Record No. 3034) to 291 (NC-DAOT-10, pl. 1, Record No. 1153). Plate 10 is a regional map that shows the distribution and a range of values for the $D / P R$ factor in the area where Unit $\mathrm{F}$ has waste-storage potential. As indicated by the relative areal extent of the value patterns on the map, a D/PR factor ranging in value from 20 to 40 is dominant within Unit $\mathrm{F}$.

A total thickness for the shale that immediately overlies and underlies each potential reservoir sand delineated in Unit $\mathrm{F}$ is listed on the well-record sheets, together with a value for the calculated thickness (feet) of shale per foot of reservoir sand.

In areas where Unit $F$ is judged to have wastestorage potential, a maximum thickness of 270 feet is recorded for a shale that immediately overlies a reservoir sand (NC-DA-OT-12, pl. 1, Record No. 1152). The maximum value calculated for the thickness of a shale seal per foot of reservoir sand in the same well is 9 feet. Within the potential wastestorage environments present in Unit $F$, the average thickness of overlying shale seals is about 48.7 feet, and the average value for the calculated thickness of these shale seals per foot of reservoir sand is about 1.3 feet. Plate 9 shows the regional distribution of the averaged thickness (feet) per foot of potential waste-reservoir sand for the shale seals that immediately overlie the reservoir sands in Unit $F$. The scale of values ranges from less than 1 to more than 3 feet. The relative areal extent of the values indicates that the dominant thickness is from 1.0 to 2.0 feet of shale per foot of potential reservoir sand. A maximum thickness of 270 feet is recorded for a shale seal that immediately underlies a reservoir sand (NC-DA-OT-12, pl. 1, Record No. 1152), 
and the maximum value calculated for the thickness of a shale seal per foot of reservoir sand is about 6.8 feet in the same well. In Unit F's potential wastestorage environments, the average thickness of underlying shale seals is about $\mathbf{4 7 . 3}$ feet, and the average value for the calculated thickness of these shale seals per foot of reservoir sand is about 1.2 feet. Plate 10 shows the distribution of the averaged thickness (feet) per foot of potential reservoir sand for the shale seals that immediately underlie the reservoir sands in Unit F. As indicated by the relative areal extent of the patterns mapped, the dominant value is the one ranging from 1.0 to 2.0 feet of shale per foot of reservoir sand.

A summary of the data for Unit $F$ is listed in table 2.

\section{SUMMARY}

The subsurface data derived from the study of well cuttings and geophysical logs of scattered boreholes were used to select an environment having the geologic requirements for waste storage. The environment is defined as follows:

A sand or sandstone layer, 20 feet or greater in thickness, that is directly overlain and underlain by a shale layer, 20 feet or greater in thickness, and which occurs in Units $F, G$, or $\mathbf{H}$, in areas where the top of each of these units lies at a depth greater than 1,500 feet below mean sea level.

By definition, the environment contains relatively porous and permeable rock (reservoir rock, sand or sandstone) that is directly overlain and underlain by relatively impermeable rock (reservoir-seal rock, shale or clay). The distribution of the environment in the regional sediment mass (pls. 2-19) is shown, indirectly, by means of mappable geologic parameters that show the distribution of the reservoir and reservoir-seal components of the environment and their interrelationship.

The geologic parameters mapped for each of the geologic units judged to have waste-storage potential include:

1. Unit thickness and sand thickness.

2. Averaged depth to the tops of the unit's potential waste-reservoir sand.

3. Thickness of potential waste-reservoir sand.

4. Thickness of overlying shale per foot of potential waste-reservoir sand.

5. Thickness of underlying shale per foot of potential waste-reservoir sand.
6. Overburden thickness per foot of potential wastereservoir sand.

The maps and other data make available to management a range of values for the geologic parameters that define waste-storage environments. The maps may be used, within a cost-risk-benefit framework, to assess the relative waste-storage potential of different parts of the sediment mass and to select, for detailed drilling, the areas which seem to be favorable.

The criteria and techniques presented in this report may, with only slight modification, be used as guidelines for defining and delineating waste-storage environments in other geographic areas. Also, they may be used to delineate other types of sedimentary environments in the subsurface that have economic potential.

\section{REFERENCES}

Brown, P. M., Miller, J. A., and Swain, F. M., 1972, Structural and stratigraphic framework, and spatial distribution of permeability of the Atlantic Coastal Plain, North Carolina to New York: U.S. Geol. Survey Prof. Paper 796, 79 p., 59 pl.

Cook, T. D., ed., 1972, Underground waste management and environmental implications, Symposium Proc.: Am. Assoc. Petroleum Geologists Mem. 18, 412 p.

Galley, J. E., ed., 1968, Subsurface disposal in geologic basins-A study of reservoir strata: Am. Assoc. Petroleum Geologists Mem. 10, 253 p.

Katz, D. L., and Coats, K. H., 1968, Underground storage of fluids: Ulrich's Books, Inc., Ann Arbor, Mich., 575 p.

Katz, D. L., Tek, M. R., Coats, K. H., Katz, M. L., Jones, S. C., and Miller, M. C., 1963, Movement of underground water in contact with natural gas: New York, N.Y., Am. Gas Assoc., Monograph for Michigan Univ. Project No.$31,323 \mathrm{p}$.

Pettijohn, F. J., 1957, Sedimentary rocks [2d ed.]: New York, Harper and Brothers, $718 \mathrm{p}$.

Rima, D. R., Chase, E. B., and Myers, B. M., 1971, Subsurface waste disposal by means of wells-a selective annotated bibliography: U.S. Geol. Survey Water-Supply Paper $2020,305 \mathrm{p}$.

Russell, W. L., 1960, Principles of petroleum geology: New York, McGraw-Hill Book Co., 490 p.

Witherspoon, P. A., Javandel, I., Neuman, S. P., and Freeze, R. A., 1967, Interpretation of aquifer gas storage conditions from water pumping tests: Am. Gas Assoc., Monograph for Univ. Calif. Project No. NS-38, 273 p.

Young, Addison, and Galley, J. E., eds., 1965, Fluids in subsurface environments-A symposium: Am. Assoc. Petroleum Geologists Mem. 4, $414 \mathrm{p}$. 
BASIC DATA 
Well No.: NC-GAR-OT-7

Record No.: 1035

State: North Carolina

County: Carteret
Well name: Coastal Plains, Huntley Davis No. 1

Latitude: 344350

Longitude: 0763430

Depth of well_-_ $\mathrm{ft}$

Depth of well (SLD) -

Bievation of measuring point above ground level_...-ft_-..-12

Elevation of ground level .....ft....8

\begin{tabular}{|c|c|c|c|}
\hline Potential reservoir sand determination & Unit $\mathrm{F}$ & Unit $\mathbf{G}$ & Unit $\mathbf{H}$ \\
\hline Depth to top of unit (SLD) & $-3,195$ & $-3,670$ & $-4,600$ \\
\hline Thickness of unit (feet) & 475 & 930 & 338 \\
\hline Unit's total sand thickness (feet/percent) & $155 / 33$ & $250 / 27$ & $250 / 74$ \\
\hline Unit's total shale thickness (feet/percent) & $300 / 63$ & $380 / 41$ & $30 / 9$ \\
\hline Unit's sand-shale ratio & 0.5 & 0.7 & 8.3 \\
\hline Number of potential reservoir sands in unit & 3 & 0 & 0 \\
\hline Total thickness (feet) of unit's potential reservoir sands & 80 & -..-..... & $-\ldots-.-1-$ \\
\hline Average thickness (feet) of unit's potential reservoir sands & 27 & -..-..-.-. & -..-.-.-. \\
\hline Maximum thickness (feet) of a potential reservoir sand layer in unit & 40 & -...-.-. & -.-.-.-.-- \\
\hline Ratio-unit's potential reservoir sand thickness: unit's total thickness & 0.17 & -..--..-.- & $---\cdots--$. \\
\hline Ratio-unit's potential reservoir sand thickness: unit's total sand thickness & 0.52 & -.-.--.-- & -...-.-.- \\
\hline $\begin{array}{l}\text { Thickness (feet)-Immediately underlying shale seal-potential reservoir sand- } \\
\text { immediately overlying shale seal. }\end{array}$ & $\begin{array}{l}26-20-140 \\
90-40-20 \\
80-20-90\end{array}$ & -------- & $----n--$ \\
\hline $\begin{array}{l}\text { Ratio (feet)-Thickness of immediately underlying shale seal:thickness of } \\
\text { potential reservoir sand:thickness of immediately overlying shale seal. }\end{array}$ & $\begin{array}{l}1.30: 1: 7.00 \\
2.25: 1: 0.50 \\
4.00: 1: 4.50\end{array}$ & $--\ldots---$ & \\
\hline Depth to top of uppermost potential reservoir sand (SLD) & 3,410 & 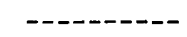 & 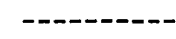 \\
\hline Depth to top of lowermost potential reservoir sand (SLD) & 3,650 & & \\
\hline Average depth to top of unit's potential reservoir sand (SLD) & 3,526 & --------- & ---- \\
\hline Percent of potential reservoir sand in upper third of unit & 0 & & -... \\
\hline Percent of potential reservoir sand in middle third of unit & 24 & ----- & \\
\hline $\begin{array}{l}\text { Percent of potential reservoir sand in lower third of unit } \\
\mathrm{D} / \mathrm{PR} \text { factor (average depth of potential reservoir sand occurrence/total thick- }\end{array}$ & $\begin{array}{l}76 \\
42\end{array}$ & None & None \\
\hline & & & \\
\hline
\end{tabular}

Geophysical logs: Electric, Gamma

Well No.: NC-CR-OT-30

Record No.: 1071

Well Name: Carolina Pet. Co., Bryan No. 1

State: North Carolina

Latitude: 345055

County: Craven

Longitude: 0765745

Depth of well-_.ft---2,435

Depth of well (SLD) -...ft_..-_2,394

Elevation of measuring point above ground level ft $\mathrm{ft}$

Elevation of ground level.....ft_..-32

\begin{tabular}{|c|c|c|c|}
\hline Potential reservoir sand determination & Unit $\mathbf{F}$ & Unit G & Unit $\mathbf{H}$ \\
\hline Depth to top of unit (SLD) & $-2,069$ & Absent & Absent \\
\hline Thickness of unit (feet) & 300 & -------- & -------- \\
\hline Unit's total sand thickness (feet/percent) & $120 / 40$ & -..--.-.-- & -.--.-.-- \\
\hline Unit's total shale thickness (feet/percent) & $180 / 60$ & ------- & -------- \\
\hline Unit's sand-shale ratio & 0.7 & $-1-1--1$ & \\
\hline Number of potential reservoir sands in unit & 2 & -..--.-- & -...-.-.-. \\
\hline Total thickness (feet) of unit's potential reservoir sands & 90 & $-1--1--1$ & 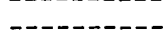 \\
\hline Average thickness (feet) of unit's potential reservoir sands & 45 & ------- & -------- \\
\hline Maximum thickness (feet) of a potential reservoir sand layer in unit & 70 & ------- & -........ \\
\hline Ratio-unit's potential reservoir sand thickness:unit's total thickness & 0.30 &.------- & $-----n---$ \\
\hline Ratio-unit's potential reservoir sand thickness:unit's total sand thickness & 0.75 & -.-.-.---- & ......- \\
\hline $\begin{array}{l}\text { Thickness (feet) - Immadiatelv underlying shale seal-potential reservoir sand- } \\
\text { immediately overlying shale seal. }\end{array}$ & $\begin{array}{l}60-70-60 \\
30-20-60\end{array}$ & $-\ldots----$ & \\
\hline $\begin{array}{l}\text { Ratio (feet) - Thickness of immediately underlying shale seal:thickness of } \\
\text { potential reservoir sand:thickness of immediately overlying shale seal. }\end{array}$ & $\begin{array}{l}0.86: 1: 0.86 \\
1.50: 1: 3.00\end{array}$ & --.-- & \\
\hline Depth to top of uppermost potential reservoir sand (SLD) & 2,129 & -.-.-.-.-- &.$--\ldots$ \\
\hline Depth to top of lowermost potential reservoir sand (SLD) & 2,254 & -----1 & \\
\hline Average depth to top of unit's potential reservoir sand (SLD) & 2,191 & ------- & --1 \\
\hline Percent of potential reservoir sand in upper third of unit & 0 & -------- & ------ \\
\hline Percent of potential reservoir sand in middle third of unit & 78 & ------- & ---- \\
\hline Percent of potential reservoir sand in lower third of unit & 22 & ------- & \\
\hline $\begin{array}{l}\text { D/PR factor (average depth of potential reservoir sand occurrence/total thick- } \\
\text { ness of unit's potential reservoir sand). }\end{array}$ & 24 & & \\
\hline
\end{tabular}


Well No.: NC-GAR-OT-8

Record No.: 1080

State: North Carolina

County: Carteret
Well Name: F. L. Karston, Laughton No. 1

Latitude: 344540

Longitude: 0764330

Depth of well-_ft--- 4,044

Depth of well (SLD) --.ft-- 4,025

Elevation of measuring point above ground level_-.-.ft_-.--9

Elevation of ground level_....ft...- 10

Potential reservoir sand determination

Thickness of unit (feet)

(feet/percent)

Unit's total sand thickness (feet/percent)

Unit's total shale thickness (feet/percent)

Unit's sand-shale ratio

Number of potential reservoir sands in unit

Total thickness (feet) of unit's potential reservoir sands

Average thickness (feet) of unit's potential reservoir sands

Maximum thickness (feet) of a potential reservoir sand layer in unit -

Ratio-unit's potential reservoir sand thickness:unit's total thickness _.......

Ratio-unit's potential reservoir sand thickness: unit's total sand thickness -..-

Thickness (feet) - Immediately underlying shale seal-potential reservoir sandimmediately overlying shale seal.

Ratio (feet)-Thickness of immediately underlying shale seal:thickness of potential reservoir sand:thickness of immediately overlying shale seal.

Depth to top of uppermost potential reservoir sand (SLD)

Depth to top of lowermost potential reservoir sand (SLD)

of potential reservoir sand in upper third of unit

Percent of potential reservoir sand in middle third of unit

Percent of potential reservoir sand in lower third of unit

$\mathrm{D} / \mathrm{PR}$ factor (average depth of potential reservoir sand occurrence/total thickness of unit's potential reservoir sand).

\begin{tabular}{|c|c|c|}
\hline Unit $F$ & Unit G & Unit $\mathbf{H}$ \\
\hline$-2,711$ & $-3,214$ & $-3,931$ \\
\hline 503 & 717 & 80 \\
\hline $288 / 57$ & $300 / 42$ & $80 / 100$ \\
\hline $215 / 43$ & $362 / 50$ & 0 \\
\hline 1.3 & 0.9 & $\infty$ \\
\hline 5 & 1 & 0 \\
\hline 210 & 85 & 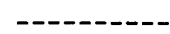 \\
\hline 42 & 85 & $--1-1-1$ \\
\hline 80 & 85 & - - - - \\
\hline 0.41 & 0.19 & $-0-1-1$ \\
\hline 0.73 & 0.28 & --- - - - \\
\hline $55-30-40$ & $50-85-175$ & --------- \\
\hline $20-25-25$ & & \\
\hline $50-35-20$ & & \\
\hline $\begin{array}{c}25-80-50 \\
1.83: 1: 1.33\end{array}$ & & \\
\hline $\begin{array}{l}1.83: 1: 1.33 \\
1.13: 1: 1.38\end{array}$ & $0.59: 1: 2.06$ & -- \\
\hline $0.80: 1: 1.00$ & & \\
\hline $1.43: 1: 0.57$ & & \\
\hline $0.31: 1: 0.63$ & & \\
\hline 2,811 & 3,736 & --- \\
\hline 3,141 & 3,736 & $\ldots$ \\
\hline 2,979 & 3,736 & $-\ldots-n$ \\
\hline 14 & 0 & ----- \\
\hline 48 & 0 & \\
\hline 38 & 100 & \\
\hline 14 & 44 & None \\
\hline
\end{tabular}

Geophysical logs: Flectric

Well No.: NC-CAR-OT-9

Record No.: 1082

Latitude: 345850

State: North Carolina

Longitude: 0763900

County: Carteret

Depth of well

Depth of well (SLD) -...-ft

Elevation of measuring point above ground level.....ft_...-7

Elevation of ground level.....ft....

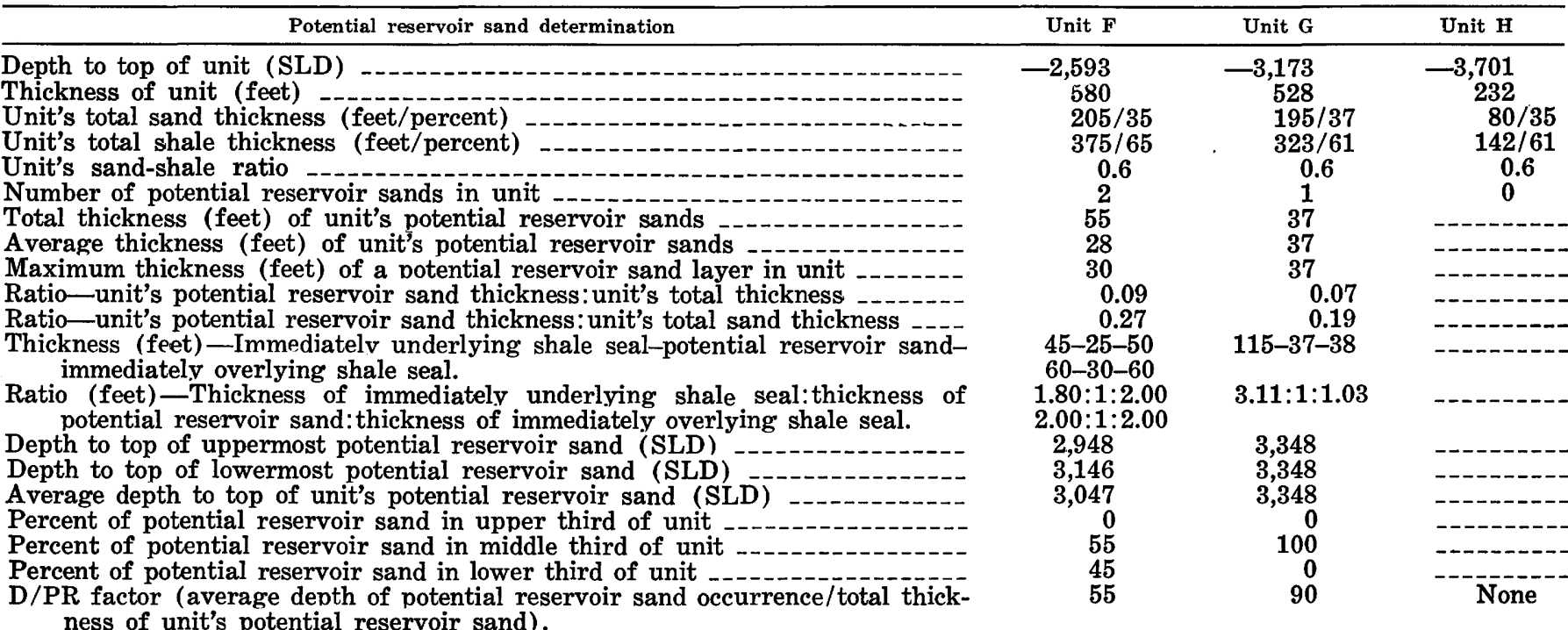


Well No.: NC-CAR-OT-11

Record No.: 1084

State: North Carolina

County: Carteret
Well name: Carolina Pet. Co., G. Carroway No. 1

Latitude: 345705

Longitude: 0763830

Depth of well

Depth of well (SLD) -

Elevation of measuring point above ground level _... $\mathrm{ft}_{\ldots} \ldots$

Elevation of ground level....-ft....8

\begin{tabular}{|c|c|c|c|}
\hline Potential reservoir sand determination & Unit $F$ & Unit $\mathbf{G}$ & Unit $\mathrm{H}$ \\
\hline Depth to top of unit (SLD) & $-2,642$ & $-3,249$ & $-3,798$ \\
\hline Thickness of unit (feet) & 607 & 549 & 246 \\
\hline Unit's total sand thickness (feet/percent) & $192 / 32$ & $120 / 22$ & $141 / 57$ \\
\hline Unit's total shale thickness (feet/percent) & $415 / 68$ & $369 / 67$ & $95 / 39$ \\
\hline Unit's sand-shale ratio & 0.5 & 0.3 & 1.5 \\
\hline Number of potential reservoir sands in unit & 1 & 1 & 0 \\
\hline Total thickness (feet) of unit's potential reservoir sands & 30 & 66 & -... \\
\hline Average thickness (feet) of unit's potential reservoir sands & 30 & 66 & $--\cdots-1$ - \\
\hline Maximum thickness (feet) of a potential reservoir sand layer in unit & 30 & 66 & -....... \\
\hline Ratio-unit's potential reservoir sand thickness:unit's total thickness & 0.05 & 0.12 & \\
\hline Ratio-unit's potential reservoir sand thickness: unit's total sand thickness & 0.16 & 0.55 & $-1--$ \\
\hline $\begin{array}{l}\text { Thickness (feet)-Immediately underlying shale seal-potential reservoir sand- } \\
\text { immediately overlying shale seal. }\end{array}$ & $80-30-110$ & $30-66-20$ & \\
\hline $\begin{array}{l}\text { Ratio (feet)-Thickness of immediately underlying shale seal:thickness of } \\
\text { potential reservoir sand:thickness of immediately overlying shale seal. }\end{array}$ & $2.67: 1: 3.67$ & $0.45: 1: 0.30$ & \\
\hline Depth to top of uppermost potential reservoir sand (SLD) & 3,122 & 3,732 & $-\ldots--$ \\
\hline Depth to top of lowermost potential reservoir sand (SLD) & 3,122 & 3,732 & -..-.- \\
\hline Average depth to top of unit's potential reservoir sand (SLD) & 3,122 & 3,732 & \\
\hline Percent of potential reservoir sand in upper third of unit & 0 & 0 & $----1--$ \\
\hline Percent of potential reservoir sand in middle third of unit & 0 & 0 & \\
\hline Percent of potential reservoir sand in lower third of unit & 100 & 100 & \\
\hline $\begin{array}{l}\text { D/PR factor (average depth of potential reservoir sand occurrence/total thick- } \\
\text { ness of unit's potential reservoir sand). }\end{array}$ & 104 & 57 & None \\
\hline
\end{tabular}

Geophysical logs: Electric

Well No.: NC-CAR-OT-12

Record No.: 1085

Well name: Carolina Pet. Co., Wallace No. 1

State: North Carolina

Latitude: 345845

County: Carteret

Longitude: 0763800

Depth of well_-_ft_--_4,024

Depth of well (SLD)

Elevation of measuring point above ground level

Elevation of ground level

Depth to top of unit (SLD)

otential reservoir sand determination

\begin{tabular}{c}
\hline Unit F \\
$-2,601$ \\
608 \\
$225 / 37$ \\
$383 / 63$ \\
0.6 \\
5 \\
168 \\
34 \\
55 \\
0.28 \\
0.75 \\
$50-27-40$ \\
$40-55-70$ \\
$70-30-75$ \\
$20-22-35$ \\
$45-34-22$ \\
$1.85: 1: 1.48$ \\
$0.73: 1: 1.27$ \\
$2.33: 1: 2.50$ \\
$0.91: 1: 1.59$ \\
$1.32: 1: 0.65$ \\
2,727 \\
3,177 \\
2,961 \\
15 \\
31 \\
54 \\
18
\end{tabular}

\begin{tabular}{cc} 
Unit G & Unit $H$ \\
\hline$-3,209$ & $-3,759$ \\
550 & 246 \\
I90/34 & $100 / 41$ \\
$350 / 64$ & $146 / 59$ \\
0.5 & 0.7 \\
2 & 1 \\
63 & 20 \\
32 & 20 \\
43 & 20 \\
0.11 & 0.08 \\
0.33 & 0.20 \\
$20-20-70$ & $20-20-35$
\end{tabular}

Thickness of unit (feet) -

Unit's total sand thickness (feet/percent)

Unit's total shale thickness (feet/percent)

Unit's sand-shale ratio _...

Number of potential reservoir sands in unit

Total thickness (feet) of unit's potential reservoir sands

Average thickness (feet) of unit's potential reservoir sands

Maximum thickness (feet) of a potential reservoir sand laver in unit -

Ratio-unit's potential reservoir sand thickness:unit's total thickness _.......

Ratio-unit's potential reservoir sand thickness:unit's total sand thickness - . -

Thickness (feet) - Immediatelv underlying shale seal-potential reservoir sandimmediately overlying shale seal.

Ratio (feet)-Thickness of immediately underlying shale seal:thickness of potential reservoir sand:thickness of immediately overlying shale seal.

Depth to top of uppermost potential reservoir sand (SLD)

Depth to top of lowermost potential reservoir sand (SLD)

Average depth to top of unit's potential reservoir sand (SLD)

Percent of potential reservoir sand in upper third of unit

Percent of potential reservoir sand in middle third of unit

Percent of potential reservoir sand in lower third of unit

D/PR factor (average depth of potential reservoir sand occurrence/total thickness of unit's potential reservoir sand).
$110-43-20$

$1.00: 1: 3.50$

2.56:1:0.47

$1.00: 1: 1.75$

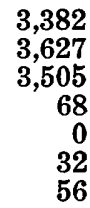

3,965

3,965

3,965

3,627

505

68

32

56

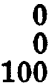


Record No.: 1086

State: North Carolina

County: Carteret

\section{Well No.: NC-CAR-OT-6}

Well name: Coastal Plains, Yeatman No. 1

Latitude: 345430

Longitude: 0763730

Depth of well-_-ft_.._4,096

Depth of well (SLD) -

Elevation of measuring point above ground level

Elevation of ground level_.._ft_._.10

Potential reservoir sand determination

Unit $\mathbf{F}$

Depth to top of unit (SLD)

Thickness of unit (feet)

Unit's total sand thicknes

Unit's total shale thickness (feet/percent)

Unit's sand-shale ratio

Number of potential reservoir sands in unit

Total thickness (feet) of unit's potential reservoir sands

Average thickness (feet) of unit's potential reservoir sands

Maximum thickness (feet) of a potential reservoir sand layer in unit

Ratio-unit's potential reservoir sand thickness:unit's total thickness

Ratio-unit's potential reservoir sand thickness: unit's total sand thickness

Thickness (feet) - Immediately underlying shale seal-potential reservoir sandimmediately overlying shale seal.

Ratio (feet)-Thickness of immediately underlying shale seal:thickness of potential reservoir sand:thickness of immediately overlying shale seal.

Depth to top of uppermost potential reservoir sand (SLD)

Depth to top of lowermost potential reservoir sand (SLD)

Average depth to top of unit's potential reservoir sand (SLD)

Percent of potential reservoir sand in upper third of unit

Percent of potential reservoir sand in middle third of unit -

Percent of potential reservoir sand in lower third of unit

$\mathrm{D} / \mathrm{PR}$ factor (average depth of potential reservoir sand occurrence/total thickness of unit's potential reservoir sand).

\begin{tabular}{|c|c|c|}
\hline Unit $F$ & Unit $G$ & Unit $\mathrm{H}$ \\
\hline$-2,750$ & $-3,295$ & $-3,990$ \\
\hline 545 & 695 & $>86$ \\
\hline $200 / 37$ & $220 / 32$ & --n------- \\
\hline $345 / 63$ & $385 / 55$ & --------- \\
\hline 0.6 & 0.6 & -------1 \\
\hline 5 & 1 & $---1-1-1$ \\
\hline 120 & 60 & $--1-1-1$ \\
\hline 25 & 60 & $-0-1-1$ \\
\hline 30 & 60 & $-\ldots$ \\
\hline 0.22 & 0.08 & - \\
\hline 0.68 & 0.27 & $-----1-1$ \\
\hline $\begin{array}{l}95-20-90 \\
90-30-40\end{array}$ & $35-60-42$ & $-1-1-1$ \\
\hline $35-20-85$ & & \\
\hline $\begin{array}{l}85-20-60 \\
60-30-42\end{array}$ & & \\
\hline $4.75: 1: 4.50$ & $0.58: 1: 0.70$ & - \\
\hline $3.00: 1: 1.33$ & & \\
\hline $1.75: 1: 4.25$ & & \\
\hline $4.25: 1: 3.00$ & & \\
\hline $2.00: 1: 1.40$ & & \\
\hline 2,840 & 3,920 & $---\infty-\infty-1$ \\
\hline 3,270 & 3,920 & $-\cdots-$ \\
\hline 3,046 & 3,920 & 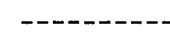 \\
\hline 42 & 0 & \\
\hline 17 & 0 & - \\
\hline 41 & 100 & - - - \\
\hline 25 & 65 & \\
\hline
\end{tabular}

Geophysical logs: Electric

Well No.: NC-CAR-OT-5

Record No.: 1090

State: North Carolina

County: Carteret
Well name: Coastal Plains, Bayland No. 1

Latitude: 345355

Longitude: 0762200

Depth of well_._._ft_-_. 5,609

Depth of we'l (SLD) _..-_tt_-_.5,59

Elevation of measuring point above ground level .....ft_....12

Elevation of ground level..... ft.... 6

Potential reservoir sand determination

Depth to top of unit (SLD)

Thickness of unit (feet)

D)

Thickness of unit (feet) -

Unit's total sand thickness (feet/percent)

Unit's total shale thickness (feet/percent)

Unit's sand-shale ratio --

Number of potential reservoir sands in unit

Total thickness (feet) of unit's potential reservoir sands

Average thickness (feet) of unit's potential reservoir sands

Maximum thickness (feet) of a potential reservoir sand layer in unit .....

Ratio-unit's potential reservoir sand thickness:unit's total thickness - - - - -

Ratio-unit's potential reservoir sand thickness: unit's total sand thickness -..-

Thickness (feot) - Immodiatelv underlying shale seal-potential reservoir sandimmediately overlying shale seal.

Ratio (feet)-Thickness of immediately underlying shale seal:thickness of potential reservoir sand:thickness of immediately overlying shale seal.

Depth to top of uppermost potential reservoir sand (SLD)

Depth to top of lowermost potential reservoir sand (SLD)

Average depth to top of unit's potential reservoir (SThe

Percent of potential reservoir sand in upper third of unit

Percent of potential reservoir sand in middle third of unit .

Percent of potential reservoir sand in lower third of unit

$\mathrm{D} / \mathrm{PR}$ factor (average depth of potential reservoir sand occurrence/total thickness of unit's potential reservoir sand).

\begin{tabular}{ccc} 
Unit F & Unit G & Unit H \\
\hline$-3,334$ & $-4,092$ & $-5,034$ \\
758 & 942 & 519 \\
$328 / 43$ & $252 / 27$ & $145 / 28$ \\
$345 / 46$ & $580 / 61$ & $\mathbf{2 8 6 / 5 5}$ \\
1.0 & 0.4 & 0.5 \\
2 & 3 & 1 \\
120 & 125 & 35 \\
60 & 41 & 35 \\
90 & 80 & 35 \\
0.16 & 0.13 & 0.07 \\
0.37 & 0.50 & 0.24 \\
$30-30-25$ & $85-80-25$ & $70-35-20$ \\
$25-90-40$ & $50-20-30$ & \\
& $30-25-20$ & \\
$1.00: 1: 0.83$ & $1.06: 1: 0.31$ & $2.00: 1: 0.5$ \\
$0.28: 1: 0.44$ & $2.50: 1: 1.50$ & \\
& $1.20: 1: 0.80$ & \\
3,802 & 4,512 & 5,444 \\
3,912 & 4,952 & 5,444 \\
3,857 & 4,679 & 5,444 \\
0 & 0 & 0 \\
0 & 36 & 0 \\
100 & 64 & 100 \\
32 & 37 & 156
\end{tabular}

Geophysical logs: Electric 
Well No.: NC-PAM-OT-3

Record No.: 1121

State: North Carolina

County: Pamlico
Well name: Carolina Pet., Atlas Plywood No. 1

Latitude: 350515

Longitude: 0764035

Depth of well----ft---3,425

Depth of well (SLD)

Elevation of measuring point above ground level__-_ft_._._9

Elevation of ground level_.... ft._.-.8

\begin{tabular}{|c|c|c|c|}
\hline Potential reservoir sand determination & Unit F & Unit $G$ & Unit $\mathbf{H}$ \\
\hline Depth to top of unit (SLD) & $-2,353$ & $-2,981$ & Absent \\
\hline Thickness of unit (feet) & 628 & 424 & --------- \\
\hline Unit's total sand thickness (feet/percent) & $225 / 36$ & $155 / 37$ & --------- \\
\hline Unit's total shale thickness (feet/percent) & $403 / 64$ & $229 / 54$ & --------- \\
\hline Unit's sand-shale ratio & 0.6 & 0.7 & -------- \\
\hline Number of potential reservoir sands in unit & 1 & 2 & -------- \\
\hline Total thickness (feet) of unit's potential reservoir sands & 32 & $\mathbf{5} \overline{\mathbf{5}}$ & -------- \\
\hline Average thickness (feet) of unit's potential reservoir sands & 32 & 28 & --------- \\
\hline Maximum thickness (feet) of a potential reservoir sand layer in unit & 32 & 30 & -------- \\
\hline Ratio-unit's potential reservoir sand thickness:unit's total thickness & 0.06 & 0.13 & $--\cdots---n$ \\
\hline Ratio-unit's potential reservoir sand thickness: unit's total sand thickness & 0.17 & $\mathbf{0 . 3 5}$ & -------- \\
\hline $\begin{array}{l}\text { Thickness (feet) - Immediately underlying shale seal-potential reservoir sand- } \\
\text { immediately overlying shale seal. }\end{array}$ & $40-32-90$ & $\begin{array}{l}25-25-25 \\
25-30-20\end{array}$ & -- \\
\hline $\begin{array}{l}\text { Ratio (feet) Thickness of immediately underlying shale seal:thickness of } \\
\text { potential reservoir sand:thickness of immediately overlying shale seal. }\end{array}$ & $1.25: 1: 2.81$ & $\begin{array}{l}1.00: 1: 1.00 \\
0.83: 1: 0.66\end{array}$ & \\
\hline Depth to top of uppermost potential reservoir sand (SLD) & 2,793 & 3,223 & ---------- \\
\hline Depth to top of lowermost potential reservoir sand (SLD) & 2,793 & 3,278 & --------- \\
\hline Average depth to top of unit's potential reservoir sand (SLD) & 2,793 & 3,251 & \\
\hline Percent of potential reservoir sand in upper third of unit & 0 & 0 & -------- \\
\hline Percent of potential reservoir sand in middle third of unit & $\mathbf{0}$ & 55 & -------- \\
\hline Percent of potential reservoir sand in lower third of unit & 100 & 45 & -------- \\
\hline $\begin{array}{l}\mathrm{D} / \text { PR factor (average depth of potential reservoir sand occurrence/total thick- } \\
\text { ness of unit's potential reservoir sand). }\end{array}$ & 87 & 59 & \\
\hline
\end{tabular}

Geophysical logs: Electric

Well No.: NC-PAM-OT-9

Record No.: 1122

State: North Carolina

County: Pamlico

Well name: Carolina Pet., N.C. Pulpwood No. 1

Latitude: 350435

Longitude: 0763900

Depth of well-_.ft_-_. 3,666

Depth of well (SLD) _. -_.ft_-_-_3,654

Dround level

Elevation of ground level

Potential reservoir sand determination

Depth to top of unit (SLD)

Thickness of unit (feet)

Unit's total sand thickness (feet/percent

feet/percent) -

shale thickness (feet/percent)

Number of potential reservoir sands in unit

Total thickness (feet) of unit's potential reservoir sands

Average thickness (feet) of unit's potential reservoir sands

Maximum thickness (feet) of a potential reservoir sand layer in unit .

Ratio-unit's potential reservoir sand thickness:unit's total thickness _.......

Ratio-unit's potential reservoir sand thickness:unit's total sand thickness - - -

Thickness (feet) - Immediately underlying shale seal-potential reservoir sandimmediately overlying shale seal.

Ratio (feet) - Thickness of immediately underlying shale seal:thickness of potential reservoir sand:thickness of immediately overlying shale seal.

Depth to top of uppermost potential reservoir sand (SLD)

Depth to top of lowermost potential reservoir sand (SLD)

Average depth to top of unit's potential reservoir sand (SLD)

Percent of potential reservoir sand in upper third of unit

Percent of potential reservoir sand in middle third of unit .......

Percent of potential reservoir sand in lower third of unit

D/PR factor (average depth of potential reservoir sand occurrence/total thickness of unit's potential reservoir sand).

\begin{tabular}{ccc} 
Unit $F$ & Unit G & Unit H \\
\hline$-2,461$ & $-3,083$ & $-3,564$ \\
622 & 481 & 84 \\
$155 / 25$ & $175 / 36$ & 0 \\
$457 / 73$ & $276 / 58$ & $84 / 100$ \\
0.3 & 0.6 & 0 \\
4 & 2 & 0 \\
120 & 65 & - \\
30 & 33 & - \\
35 & 35 & - \\
0.19 & 0.14 & - \\
0.77 & 0.37 & - \\
$35-35-55$ & $20-30-80$ & - \\
$90-30-30$ & $80-35-20$ &
\end{tabular}

32-30-55

$55-25-155$

$1.00: 1: 1.57$

$3.00: 1: 1.00$

1.07:1:1.83

$2.20: 1: 6.20$

2,638

3,038

2,813

21

21

54

54
23

3.228

3,358

3,285

0
100

100

51

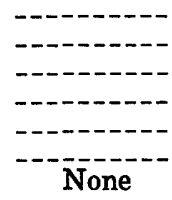


Well No.: NC-HY-OT-6

Record No.: 1150

State: North Carolina

County: Hyde
Well name: E. F. Blair \& Assoc., Ballance No. 1 Latitude: 352725

Longitude: 0760150

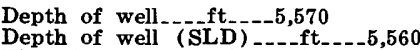

Eepth of well (SLD)

Elevation of measuring point above $\mathrm{g}$

Potential reservoir sand determination

\begin{tabular}{c} 
Unit F \\
\hline 3,125 \\
795 \\
$465 / 5$ \\
$280 / 35$ \\
1.7 \\
5 \\
232 \\
46 \\
110 \\
0.2 \\
0.5
\end{tabular}

100-

$25-32-25$

$25-22-35$

$35-110-20$

$50-40-40$

3.57:1:0.89

$0.78: 1: 0.78$

1.14:1:1.59

$0.32: 1: 0.18$

1.25:1:1.00

3,325

3,890

3,695

17

0
83

16

\begin{tabular}{cc} 
Unit G & Unit $H$ \\
\hline 3,920 & $-4,910$ \\
990 & $>650$ \\
$265 / 27$ & - \\
$675 / 68$ & - \\
0.4 & - \\
3 & - \\
245 & - \\
81 & - \\
140 & - \\
0.25 & \\
0.92 &
\end{tabular}

$270-50-85$

$0.25: 1: 0.64$

1.64:1:4.91

5.40:1:1.70

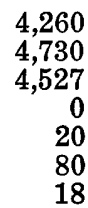

- - - - - - ----n---- - - - - - --- - - - - $-------\cdots$ -..--.-.$--------1$

Percent of potential reservoir sand in lower third of unit

$\mathrm{D} / \mathrm{PR}$ factor (average depth of potential reservoir sand occurrence/total thickness of unit's potential reservoir sand).

Geophysical logs: Gamma Ray-Neutron

Well No.: NC-HY-OT-11

Record No.: 1151

Well name: Socony Mobile, State of N.C. No. 3

Latitude: 351825

State: North Carolina

Longitude: 0754945

Depth of we'l-_ft_- 7,314

Depth of well (SLD)

Filevation of measuring point above ground level $\mathrm{ft}$

Elevation of ground level_._._ft_-_-_1.5

\begin{tabular}{|c|c|c|c|}
\hline Potential reservoir sand determination & Unit $F$ & Unit G & Unit $\mathbf{H}$ \\
\hline $\begin{array}{l}\text { Depth to top of unit (SLD) } \\
\text { Thickness of unit (feet) } \\
\text { Unit's total sand thickness (feet/percent) } \\
\text { Unit's total shale thickness (feet/percent) } \\
\text { Unit's sand-shale ratio } \\
\text { Number of potential reservoir sands in unit } \\
\text { Total thickness (feet) of unit's potential reservoir sands } \\
\text { Average thickness (feet) of unit's potential reservoir sands } \\
\text { Maximum thickness (feet) of a potential reservoir sand layer in unit } \\
\text { Ratio-unit's potential reservoir sand thickness: unit's total thickness } \\
\text { Ratio-unit's potential reservoir sand thickness: unit's total sand thickness } \\
\text { Thickness (feet) Immediately underlying shale seal-potential reservoir sand- } \\
\text { immediately overlying shale seal. }\end{array}$ & $\begin{array}{c}3,996 \\
958 \\
653 / 68 \\
275 / 29 \\
2.4 \\
7 \\
510 \\
73 \\
120 \\
0.53 \\
0.78 \\
25-110-35 \\
35-45-30 \\
30-40-40 \\
40-40-30 \\
40-45-40 \\
20-110-30 \\
30-120-25 \\
0.23: 1: 0.32 \\
0.78: 1: 0.67 \\
0.75: 1: 1.00 \\
1.00: 1: 0.75 \\
0.89: 1: 0.89 \\
0.18: 1: 0.27 \\
0.25: 1: 0.21\end{array}$ & $\begin{array}{c}-4,954 \\
1,162 \\
330 / 28 \\
707 / 61 \\
0.5 \\
3 \\
135 \\
45 \\
80 \\
0.12 \\
0.41 \\
140-80-60 \\
150-35-55 \\
55-20-45 \\
1.75: 1: 0.75 \\
4.29: 1: 1.57 \\
2.75: 1: 2.25\end{array}$ & $\begin{array}{c}-6,116 \\
1,120 \\
500 / 45 \\
465 / 41 \\
1.1 \\
1 \\
20 \\
20 \\
20 \\
0.02 \\
0.04 \\
20-20-50\end{array}$ \\
\hline
\end{tabular}


Well No.: NC-HY-OT-11-Continued

\begin{tabular}{|c|c|c|c|}
\hline Potential reseivoir sand determination-Continued & Unit $F$ & Unit $\mathbf{G}$ & Unit $H$ \\
\hline $\begin{array}{l}\text { Depth to top of uppermost potential reservoir sand (SLD) } \\
\text { Depth to top of lowermost potential reservoir sand (SLD) } \\
\text { Average depth to top of unit's potential reservoir sand (SLD) } \\
\text { Percent of potential reservoir sand in upper third of unit } \\
\text { Percent of potential reservoir sand in middle third of unit } \\
\text { Percent of potential reservoir sand in lower third of unit } \\
\text { D/PR factor (average depth of potential reservoir sand occurrence/total thick- }\end{array}$ & $\begin{array}{r}4,121 \\
4,906 \\
4,567 \\
45 \\
22 \\
33 \\
9\end{array}$ & $\begin{array}{r}5,186 \\
6,036 \\
5,494 \\
41 \\
0 \\
59 \\
41\end{array}$ & $\begin{array}{r}6,491 \\
6,491 \\
6,491 \\
100 \\
0 \\
0 \\
325\end{array}$ \\
\hline
\end{tabular}

Geophysical logs: Electric, Gamma, Sonic

Well No.: NC-DA-OT-12

Record No.: 1152

State: North Carolina

County: Dare
Well name: Mobile Oil Co., State of N.C. No. 2

Latitude: 352620

Longitude: 0753435

Depth of well-_-ft_-_8,386

Depth of weil (SLD) _-_ft____ 8,362

Elevation of measuring point above ground level____ft__ 222.5

Elevation of ground level_.... $\mathrm{ft}_{\text {. }} \ldots . .5$

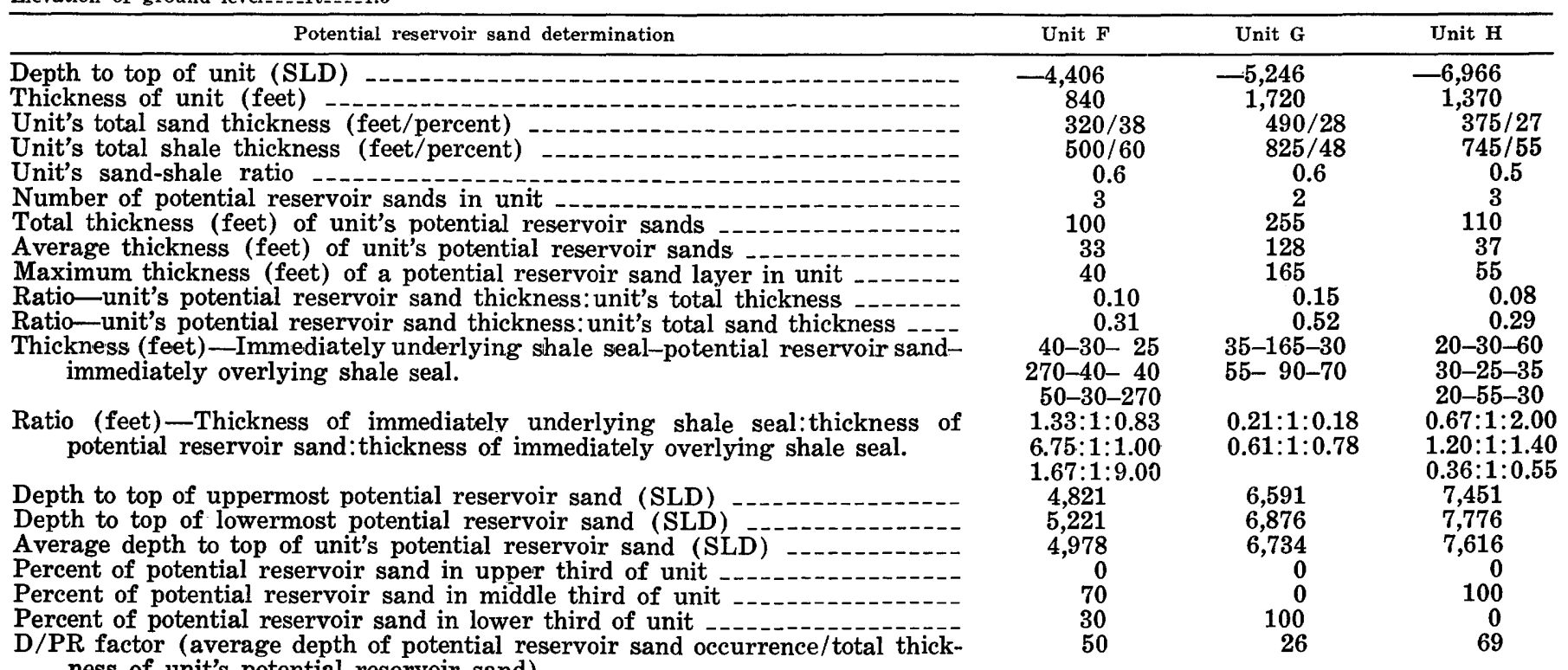
ness of unit's potential reservoir sand).

Geophysical logs: Electric, Gamma, Sonic

Well No.: NC-DA-OT-10

Record No.: 1153

State: North Carolina

County: Dare
Well name: Standard Oil N.J., Hatteras Light No. 1

Latitude: 351500

Longitude: 0753145

Depth of well

Depth of well (SLD) _._.ft____10,019

Elevation of measuring point above ground level_._-_ft_..._16

Elevation of ground level ...... $\mathrm{ft}_{-.-\ldots 9}$

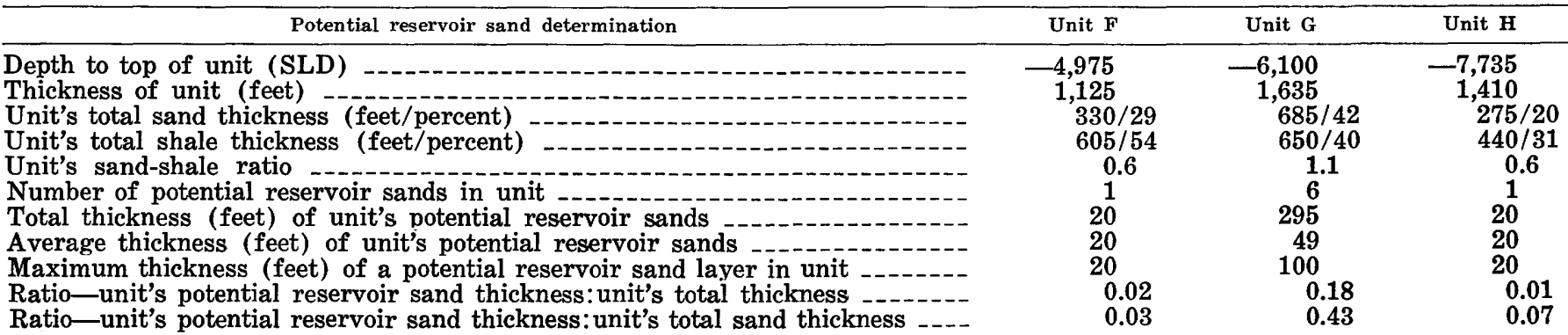


Well No.: NC-DA-OT-10-Continued

\begin{tabular}{|c|c|c|c|}
\hline Potential reservoir sand determination-Continued & Unit $\mathbf{F}$ & Unit $\mathrm{G}$ & Unit $\mathbf{H}$ \\
\hline $\begin{array}{l}\text { Thickness (feet)-Immediately underlying shale seal-potential reservoir sand- } \\
\text { immediately overlying shale seal. }\end{array}$ & $55-20-30$ & $\begin{array}{r}35-90-50 \\
55-30-145 \\
145-25-20 \\
60-30-20 \\
25-100-90 \\
40-20-40\end{array}$ & 20-20-25 \\
\hline $\begin{array}{l}\text { Ratio (feet)-Thickness of immediately underlying shale seal:thickness of } \\
\text { potential reservoir sand:thickness of immediately overlying shale seal. }\end{array}$ & $2.75: 1: 1.50$ & $\begin{array}{l}0.39: 1: 0.56 \\
1.83: 1: 4.83 \\
5.80: 1: 0.80 \\
2.00: 1: 0.67 \\
0.25: 1: 0.90 \\
2.00: 1: 2.00\end{array}$ & $1.00: 1: 1.25$ \\
\hline Depth to top of uppermost potential reservoir sand (SLD) & 5,825 & 6,220 & 8,587 \\
\hline Depth to top of lowermost potential reservoir sand (SLD) & 5,825 & 7,640 & 8,587 \\
\hline Average depth to top of unit's potential reservoir sand (SLD) & 5,825 & 6,985 & 8,587 \\
\hline Percent of potential reservoir sand in upper third of unit & $\mathbf{0}$ & 51 & 0 \\
\hline Percent of potential reservoir sand in middle third of unit & $\mathbf{0}$ & $\mathbf{0}$ & 100 \\
\hline Percent of potential reservoir sand in lower third of unit & 100 & 49 & $\mathbf{0}$ \\
\hline $\begin{array}{l}\text { D/PR factor (average depth of potential reservoir sand occurrence/total thick- } \\
\text { ness of unit's potential reservoir sand). }\end{array}$ & 291 & 24 & 429 \\
\hline
\end{tabular}

Geophysical logs: Electric

Well No.: NC-BEA-OT-12

Record No.: 1167

State: North Carolina

County: Beaufort
Well name: Coastal Plains, Zeno Ratcliff No. 1 Latitude: 353545 Longitude: 0764810

Depth of well

Depth of well (SLD) -._ft_._..1,951

Elevation of measuring point above ground level..... $\mathrm{ft}_{\text {. }} \ldots$

Elevation of ground level_...-ft_...15

\begin{tabular}{|c|c|c|c|}
\hline Potential reservoir sand determination & Unit $F$ & Unit $\mathrm{G}$ & Unit $\mathrm{H}$ \\
\hline Depth to top of unit (SLD) & $-1,385$ & Absent & Absent \\
\hline Thickness of unit (feet) & 560 & - - - - - - - & - \\
\hline Unit's total sand thickness (feet/percent) & $210 / 37$ & - - - - - - - & ------1 \\
\hline Unit's total shale thickness (feet/percent) & $345 / 62$ & - - - - - - & - \\
\hline Unit's sand-shale ratio & 0.6 & - - - - - - & $\ldots$ \\
\hline Number of potential reservoir sands in unit & 2 & -- - - - - - - & \\
\hline Total thickness (feet) of unit's potential reservoir sands & $7 \overline{5}$ & $-\ldots-n---$ & ------ \\
\hline Average thickness (feet) of unit's potential reservoir sands & 38 & 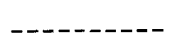 & ------ \\
\hline Maximum thickness (feet) of a potential reservoir sand layer in unit & 45 & - & -...... \\
\hline Ratio-unit's potential reservoir sand thickness: unit's total thickness & 0.13 & - - - - - & $---1--10$ \\
\hline Ratio-unit's potential reservoir sand thickness:unit's total sand thickness & 0.36 & - - - - - - - & - - - - - \\
\hline $\begin{array}{l}\text { Thickness (feet) - Immediately underlying shale seal-potential reservoir sand- } \\
\text { immediately overlying shale seal. }\end{array}$ & $\begin{array}{l}30-45-60 \\
20-35-60\end{array}$ & -------- & \\
\hline Ratio (feet)-Thickness of immediately underlying shale seal:thickness of & $0.67: 1: 1.33$ & ------- & \\
\hline potential reservoir sand:thickness of immediately overlying shale seal. & $0.57: 1: 1.71$ & & \\
\hline Depth to top of uppermost potential reservoir sand (SLD) & 1,495 & ------- & \\
\hline Depth to top of lowermost potential reservoir sand (SLD) & 1,627 & -------- & \\
\hline Average depth to top of unit's potential reservoir sand (SLD) & 1,561 & - & \\
\hline Percent of potential reservoir sand in upper third of unit & 40 & --------- & ------1 \\
\hline Percent of potential reservoir sand in middle third of unit & 60 & 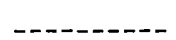 & \\
\hline Percent of potential reservoir sand in lower third of unit & 0 & - - - - - & - - - - - \\
\hline $\begin{array}{l}\mathrm{D} / \mathrm{PR} \text { factor (average depth of potential reservoir sand occurrence/total thick- } \\
\text { ness of unit's potential reservoir sand). }\end{array}$ & 21 & $---\cdots-$ & \\
\hline
\end{tabular}


Well No.: NC-BEA-OT-15

Record No.: 1168

State: North Carolina

Well name: Coastal. Plains, West Dismal No. 1

Lattitude: 353900

County: Beaufort

Longitude: 0764810

Depth of well-_. $\mathrm{ft}_{-}-\mathbf{1}_{1,938}$

Depth of well (SLD) -

Elevation of measuring point above ground level_....ft_....0

Elevation of ground level_.....ft_..._35

\begin{tabular}{|c|c|c|c|}
\hline Potential reservoir sand determination & Unit $\mathrm{F}$ & Unit $\mathrm{G}$ & Unit $H$ \\
\hline Depth to top of unit (SLD) & $-1,305$ & Absent & Absent \\
\hline Thickness of unit (feet) & 563 & -------- & --------- \\
\hline Unit's total sand thickness (feet/percent) & $245 / 44$ & $-------n$ & --------1 \\
\hline Unit's total shale thickness (feet/percent) & $318 / 56$ & --------- & -------- \\
\hline Unit's sand-shale ratio & 0.8 & -------- & --------1 \\
\hline Number of potential reservoir sands in unit & 4 & -----.--- & - - - - - - - - \\
\hline Total thickness (feet) of unit's potential reservoir sands & 121 & --------- & -------- \\
\hline Average thickness (feet) of unit's potential reservoir sands & 30 & --------- & -------- \\
\hline Maximum thickness (feet) of a potential reservoir sand layer in unit & 35 & -------- & -------- \\
\hline Ratio-unit's potential reservoir sand thickness:unit's total thickness & 0.21 & & \\
\hline Ratio-unit's potential reservoir sand thickness: unit's total sand thickness & 0.49 & -...- &.- \\
\hline $\begin{array}{l}\text { Thickness (feet) -Immediately underlying shale seal-potential reservoir sand- } \\
\text { immediately overlying shale seal. }\end{array}$ & $\begin{array}{l}20-32-35 \\
25-34-44 \\
44-20-75 \\
20-35-40\end{array}$ & ------1 & \\
\hline $\begin{array}{l}\text { Ratio (feet)-Thickness of immediately underlying shale seal:thickness of } \\
\text { potential reservoir sand:thickness of immediately overlying shale seal. }\end{array}$ & $\begin{array}{l}0.63: 1: 1.09 \\
0.74: 1: 1.29 \\
2.20: 1: 3.75 \\
0.57: 1: 1.14\end{array}$ &.- & \\
\hline Depth to top of uppermost potential reservoir sand (SLD) & 1,435 & -------- & $-\ldots-n---1$ \\
\hline Depth to top of lowermost potential reservoir sand (SLD) & 1,760 & -------- & -......... \\
\hline Average depth to top of unit's potential reservoir sand (SLD) & 1,600 & $--\cdots---1$ & -----1 \\
\hline Percent of potential reservoir sand in upper third of unit & 29 & ------- & ------- \\
\hline $\begin{array}{l}\text { Percent of potential reservoir sand in middle third of unit } \\
\text { Percent of potential reservoir sand in lower third of unit }\end{array}$ & 17 & ------- & $---\cdots--$ \\
\hline $\begin{array}{l}\text { D/PR factor (average depth of potential reservoir sand occurrence/total thick- } \\
\text { ness of unit's potential reservoir sand). }\end{array}$ & 13 & 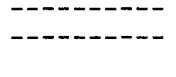 & \\
\hline
\end{tabular}

Geophysical logs: Electric

Well No.: NC-BEA-OT-13

Record No.: 1170

State: North Carolina

Well name: Coastal Plains, Rodman No. 1

County: Beaufort

Latitude: 353245

Longitude: 0764645

Depth of well-- $f \mathrm{ft}-\mathrm{C}^{-2,012}$

Depth of well (SLD) )

Elevation of measuring point above ground level.....ft.... 0

Elevation of ground level...... ft....16

\begin{tabular}{|c|c|c|c|}
\hline Potential reservoir sand determination & Unit $\mathbf{F}$ & Unit G & Unit $\mathrm{H}$ \\
\hline Depth to top of unit (SLD) & $-1,414$ & Absent & Absent \\
\hline Thickness of unit (feet) & 550 & -------- & --------- \\
\hline Unit's total sand thickness (feet/percent) & $200 / 36$ & -------- & -------- \\
\hline Unit's total shale thickness ( teet/ percent) & $340 / 62$ & -------- & --------1 \\
\hline Unit's sand-shale ratio & 0.6 & -......... & \\
\hline Number of potential reservoir sands in unit & 3 & --.--.-.-- & -...--.--- \\
\hline Total thickness (feet) of unit's potential reservoir sands & 70 & --------- &...------ \\
\hline Average thickness (feet) of unit's potential reservoir sands & 23 & -...-...... & -..--.-.-- \\
\hline Maximum thickness (feet) of a potential reservoir sand layer in unit & 30 & -...-....- & - - - - - - - - \\
\hline Ratio-unit's potential reservoir sand thickness: unit's total thickness & 0.13 & -------- & -------- \\
\hline Ratio-unit's potential reservoir sand thickness: unit's total sand thickness & 0.35 & -..--_. & \\
\hline $\begin{array}{l}\text { Thickness (feet)-Immediately underlying shale seal-potential reservoir sand- } \\
\text { immediately overlying shale seal. }\end{array}$ & $\begin{array}{l}33-30-25 \\
50-20-40 \\
40-20-30\end{array}$ & & \\
\hline $\begin{array}{l}\text { Ratio (feet)-Thickness of immediately underlying shale seal:thickness of } \\
\text { potential reservoir sand:thickness of immediately overlying shale seal. }\end{array}$ & $\begin{array}{l}1.10: 1: 0.83 \\
2.50: 1: 2.00 \\
2.00: 1: 1.50\end{array}$ & & \\
\hline Depth to top of uppermost potential reservoir sand (SLD) & 1,519 & -------- & ------ \\
\hline Depth to top of lowermost potential reservoir sand (SLD) & 1,696 & & \\
\hline Average depth to top of unit's potential reservoir sand (SLD) & 1,598 & -..-....- & $-\ldots-\ldots$ \\
\hline Percent of potential reservoir sand in upper third of unit & 57 & -........... & -------- \\
\hline Percent of potential reservoir sand in middle third of unit & 43 & -------- & ------- \\
\hline Percent of potential reservoir sand in lower third of unit & $\mathbf{0}$ & -.......- & -------- \\
\hline $\begin{array}{l}\mathrm{D} / \mathrm{PR} \text { factor (average depth of potential reservoir sand occurrence/total thick- } \\
\text { ness of unit's potential reservoir sand). }\end{array}$ & 23 & ------- & \\
\hline
\end{tabular}
ness of unit's potential reservoir sand). 
Well No.: NC-WAS-OT-2

Record No.: 1174

State: North Carolina

County: Washington

Depth of well....ft_._-_2,693

Depth of well (SLD)

Elevation of measuring point above ground level

Elevation of ground level__._-_ft_-_-_16

Potential reservoir sand determination

Depth to top of unit (SLD)

Thickness of unit (feet)

(feet/percent)

Unit's total shale thickness (feet/percent) _._.

Unit's sand-shale ratio -..-..-..-

Number of potential reservoir sands in unit

Total thickness (feet) of unit's potential reservoir sands

Average thickness (feet) of unit's potential reservoir sands

Maximum thickness (feet) of a potential reservoir sand layer in unit -

Ratio-unit's potential reservoir sand thickness:unit's total thickness ........

Ratio-unit's potential reservoir sand thickness: unit's total sand thickness -...

Thickness (feet) - Immediately underlying shale seal-potential reservoir sandimmediately overlying shale seal.

Ratio (feet)-Thickness of immediately underlying shale seal:thickness of potential reservoir sand:thickness of immediately overlying shale seal.

Depth to top of uppermost potential reservoir sand (SLD)

Depth to top of lowermost potential reservoir sand (SLD)

Average depth to top of unit's potential reservoir sand (SLD)

Percent of potential reservoir sand in upper third of unit

Percent of potential reservoir sand in middle third of unit

Percent of potential reservoir sand in lower third of unit

$\mathrm{D} / \mathrm{PR}$ factor (average depth of potential reservoir sand occurrence/total thickness of unit's potential reservoir sand).

Geophysical logs: Electric

Well No.: NC-DA-OT-9

Record No.: 1178

State: North Carolina

County: Dare

Depth of well

Depth of well (SLD) -

Elevation of measuring point above ground level_...-ft_-_-_21

Elevation of ground level $\mathrm{ft}$

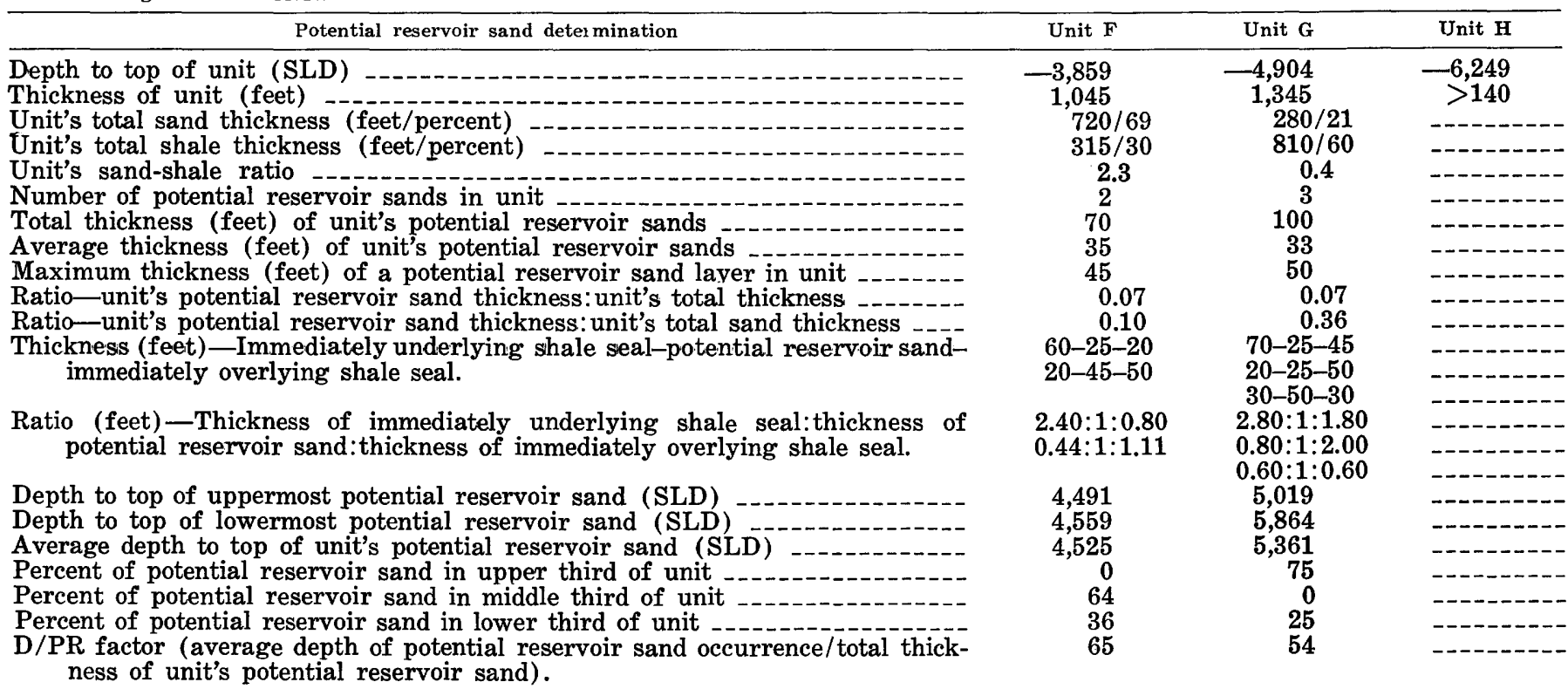

Geophysical logs: Electric
Latitude: 344330

Longitude: 0763730
Well name: Davidson Oil Co., Furbee No. 1

\begin{tabular}{|c|c|c|}
\hline Unit $F$ & Unit $G$ & Unit $H$ \\
\hline$-1,558$ & $-2,511$ & Absent \\
\hline 953 & 162 & - - - \\
\hline $375 / 39$ & $66 / 41$ & $-\cdots-1-n$ \\
\hline $578 / 61$ & $96 / 59$ & $---n-n-1$ \\
\hline 0.7 & 0.7 & $-----n$ \\
\hline 5 & 2 & $-\cdots-n-1$ \\
\hline 175 & $4 \overline{2}$ & - \\
\hline 35 & 21 & - - - - \\
\hline 55 & 22 & $\ldots-\ldots$ \\
\hline 0.18 & 0.26 & - - - - \\
\hline 0.47 & 0.64 & - - - \\
\hline $30-50-120$ & $50-20-30$ & - \\
\hline $120-20-35$ & $20-22-50$ & \\
\hline $35-55-20$ & & \\
\hline $\begin{array}{l}20-30-55 \\
55-20-95\end{array}$ & & \\
\hline $0.60: 1: 2.40$ & $2.50: 1: 1.50$ &.- \\
\hline $6.00: 1: 1.75$ & $0.91: 1: 2.27$ & \\
\hline $0.64: 1: 0.36$ & & \\
\hline $0.67: 1: 1.83$ & & \\
\hline $2.75: 1: 4.75$ & & \\
\hline 2,056 & 2,561 & $---\infty-\infty-$ \\
\hline 2,459 & 2,611 & $----\ldots-\cdots$ \\
\hline 2,241 & 2,586 & - \\
\hline 0 & 48 & $\ldots$ \\
\hline 11 & 0 & $-\ldots----n$ \\
\hline 89 & 52 & --- - \\
\hline 13 & 62 & ---------- \\
\hline
\end{tabular}

Well name: Standard Oil N.J., N.C. Esso No, 2

Latitude: 354212

Longitude: 075355 
Well No.: NG-DA-OT-14

Record No.: 1192

State: North Carolina

County: Dare

Depth of well-_- ft- $--5,147$

$-\mathrm{ft}$

Elevation of measuring point above ground level____ft_-_._8

Potential reservoir sand determination

Thickness of unit (feet)

Unit's total sand thickness (feet/percent)

Unit's total shale thickness (feet/percent)

Unit's sand-shale ratio -

Number of potential reservoir sands in unit

Total thickness (feet) of unit's potential reservoir sands

Average thickness (feet) of unit's potential reservoir sands

Maximum thickness (feet) of a potential reservoir sand layer in unit -

Ratio-unit's potential reservoir sand thickness:unit's total thickness -.....

Ratio-unit's potential reservoir sand thickness: unit's total sand thickness ---

Thickness (feet) - Immediately underlying shale seal-potential reservoir sandimmediately overlying shale seal.

Ratio (feet) - Thickness of immediately underlying shale seal:thickness of potential reservoir sand:thickness of immediately overlying shale seal.

Depth to top of uppermost potential reservoir sand (SLD)

Depth to top of lowermost potential reservoir sand (SLD)

Average depth to top of unit's potential reservoir sand (SLD)

Percent of potential reservoir sand in upper third of unit

Percent of potential reservoir sand in middle third of unit

Percent of potential reservoir sand in lower third of unit

$\mathrm{D} / \mathrm{PR}$ factor (average depth of potential reservoir sand occurrence/total thickness of unit's potential reservoir sand).

Geophysical logs: Electric, Gamma

\section{Well No.: NC-DA-OT-11}

Record No.: 1193

State: North Carolina

County: Dare

Depth of well

Depth of well (SLD) -...-ft

Elevation of measuring point above ground level _... $\mathrm{ft}$.....22.5

Elevation of ground level

Elevation of ground level_..--ft_-_--1.5

Depth to top of unit (SLD)

Thickness of unit (feet)

ifeet/percent)

Unit's total shale thickness (feet/percent)

Unit's sand-shale ratio

Number of potential reservoir sands in unit -

Total thickness (feet) of unit's potential reservoir sands

Average thickness (feet) of unit's potential reservoir sands

Maximum thickness (feet) of a potential reservoir sand layer in unit -

Ratio-unit's potential reservoir sand thickness:unit's total thickness - - - - - -

Ratio-unit's potential reservoir sand thickness:unit's total sand thickness --.-

Thickness (feet) - Immediately underlying shale seal-potential reservoir sandimmediately overlying shale seal.

Ratio (feet)-Thickness of immediately underlying shale seal:thickness of
Well name: E. F. Blair, West Va.

Pulp \& Paper No. 1

Latitude: 355150

Longitude: 0755530

\begin{tabular}{|c|c|c|}
\hline Unit $F$ & Unit $\mathbf{G}$ & Unit $\mathbf{H}$ \\
\hline$-2,547$ & $-3,644$ & $-4,699$ \\
\hline 1,097 & 1,055 & 420 \\
\hline $582 / 53$ & $190 / 18$ & $145 / 34$ \\
\hline $505 / 46$ & $790 / 75$ & $180 / 43$ \\
\hline 1.2 & 0.2 & 0.8 \\
\hline 2 & 2 & 0 \\
\hline 90 & 60 & $-\cdots$ \\
\hline 45 & 30 & ---- \\
\hline 50 & 30 & - n \\
\hline 0.08 & 0.06 & 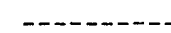 \\
\hline 0.15 & 0.32 & -. \\
\hline $20-40-55$ & $32-30-30$ & -1 \\
\hline$\overline{5} 0-50-20$ & $80-30-250$ & \\
\hline $0.50: 1: 1.38$ & $1.07: 1: 1.00$ & \\
\hline $1.00: 1: 0.40$ & $2.67: 1: 8.33$ & --- \\
\hline 2,879 & 4,179 & $-\cdots$ \\
\hline 3,073 & 4,659 & ------- \\
\hline 2,976 & 4,419 & -- \\
\hline 56 & 0 & $\ldots$ \\
\hline 44 & 50 & \\
\hline 0 & 50 & \\
\hline 33 & 74 & None \\
\hline
\end{tabular}

Well name: Mobil Oil Co., State of N.C. No. 1

Latitude: 355955

Longitude: 0755200

\begin{tabular}{ccc}
\hline Unit F & Unit G & Unit H \\
\hline$-2,486$ & $-3,586$ & $-4,676$ \\
1,100 & 1,090 & 470 \\
$440 / 40$ & $425 / 39$ & $180 / 38$ \\
$650 / 59$ & $595 / 55$ & $195 / 42$ \\
0.7 & 0.7 & 0.9 \\
5 & 8 & 1 \\
182 & 265 & 55 \\
36 & 33 & 55 \\
45 & 50 & 55 \\
0.17 & 0.24 & 0.06 \\
0.41 & 0.62 & 0.13 \\
$25-45-130$ & $35-25-45$ & $40-55-20$
\end{tabular}
potential reservoir sand:thickness of immediately overlying shale seal.

130-30-120

$120-30-20$

40-32- 20

$0.56: 1: 2.89$

4.33:1:4.00

4.00:1:0.67

$1.00: 1: 0.89$

$1.25: 1: 0.63$

Depth to top of uppermost potential reservoir sand (SLD)

Depth to top of lowermost potential reservoir sand (SLD)

Average depth to top of unit's potential reservoir sand (SLD)

Percent of potential reservoir sand in upper third of unit

Percent of potential reservoir sand in middle third of unit

P/PR factor (average depth of potential reservoir sand occurrence/total thickness of unit's potential reservoir sand).
$45-45-40$

$35-25-45$

$45-40-75$
$75-20-50$

$30-50-75$

55-35-30

$30-20-40$

40-35-30

30-40-70

$1.40: 1: 1.80$

$1.13: 1: 1.88$

$3.75: 1: 2.50$

$0.60: 1: 1.50$

$1.57: 1: 0.86$

$1.50: 1: 2.00$

1.14:1:0.86

$0.75: 1: 1.75$

3,014
3,536
3,245
0
42
58
18

3,014
3,536
3,245
0
42
58
18

4,346

4,013

49

42

15

$0.73: 1: 0.36$

4,908

4,908

4,908

0
100

100
0 
Well No.: NC-DA-OT-13

Record No.: 1194

State: North Carolina

County: Dare
Well name: E. F. Blair \& Assoc., Collins No. 1

Latitude: 355300

Longitude: 0754015

Depth of well--.ft_--6,295

Depth of well (SLD)

Elevation of measuring point above ground level

Elevation of rround level

\begin{tabular}{|c|c|c|c|}
\hline Potential reservoir sand determination & Unit $\mathbf{F}$ & Unit $\mathbf{G}$ & Unit $\mathbf{H}$ \\
\hline Depth to top of unit (SLD) & $-3,286$ & $-4,357$ & $-5,532$ \\
\hline Thickness of unit (feet) & 1,071 & 1,175 & 734 \\
\hline Unit's total sand thickness (feet/percent) & $526 / 49$ & $560 / 48$ & $204 / 28$ \\
\hline Unit's total shale thickness (feet/percent) & $485 / 45$ & $425 / 36$ & $360 / 49$ \\
\hline Unit's sand-shale ratio & 1.1 & 1.3 & 0.6 \\
\hline Number of potential reservoir sands in unit & 4 & 2 & 1 \\
\hline Total thickness (feet) of unit's potential reservoir sands & 163 & $14 \overline{5}$ & 20 \\
\hline Average thickness (feet) of unit's potential reservoir sands & 41 & 73 & 20 \\
\hline Maximum thickness (feet) of a potential reservoir sand layer in unit & 48 & 110 & 20 \\
\hline Ratio-unit's potential reservoir sand thickness:unit's total thickness & 0.15 & 0.12 & 0.03 \\
\hline Ratio-unit's potential reservoir sand thickness: unit's total sand thickness & 0.31 & 0.26 & 0.09 \\
\hline $\begin{array}{l}\text { Thickness (feet) - Immediately underlying shale seal-potential reservoir sand- } \\
\text { immediately overlying shale seal. }\end{array}$ & $\begin{array}{l}30-48-20 \\
20-45-28 \\
28-38-20 \\
35-32-60\end{array}$ & $\begin{array}{l}20-110-20 \\
20-35-35\end{array}$ & $25-20-50$ \\
\hline $\begin{array}{l}\text { Ratio (feet)-Thickness of immediately underlying shale seal:thickness of } \\
\text { potential reservoir sand:thickness of immediately overlying shale seal. }\end{array}$ & $\begin{array}{l}0.63: 1: 0.42 \\
0.44: 1: 0.62 \\
0.74: 1: 0.53 \\
1.09: 1: 1.88\end{array}$ & $\begin{array}{l}0.18: 1: 0.18 \\
0.57: 1: 1.00\end{array}$ & $1.25: 1: 2.50$ \\
\hline Depth to top of uppermost potential reservoir sand (SLD) - & 3,617 & 4,672 & 5,613 \\
\hline Depth to top of lowermost potential reservoir sand (SLD) & 4,309 & $\overrightarrow{5,417}$ & 5,613 \\
\hline Average depth to top of unit's potential reservoir sand (SLD) & 3,986 & 5,044 & 5,613 \\
\hline Percent of potential reservoir sand in upper third of unit & 20 & 26 & 100 \\
\hline Percent of potential reservoir sand in middle third of unit & 23 & 0 & 0 \\
\hline Percent of potential reservoir sand in lower third of unit & 57 & 74 & 0 \\
\hline $\begin{array}{l}\text { D/PR factor (average depth of potential reservoir sand occurrence/total thick- } \\
\text { ness of unit's potential reservoir sand). }\end{array}$ & 24 & 35 & 281 \\
\hline
\end{tabular}

Geophysical logs: Electric, Gamma

Well No.: NC-HAL-T-2

Record No.: 1197

State: North Carolina

County: Halifax
Well name: Town of Scotland Neck, Palmyra Rd. Latitude: 360655

Longitude: 0772235

Depth of well-_ft_-_338

Depth of well (SLD) _-_ft_-__-_45

Elevation of measuring point above ground level $\mathrm{ft}_{-} \mathrm{O}$

Elevation of ground level_._-_ft_-_. 93

\begin{tabular}{|c|c|c|c|}
\hline Potential reservoir sand determination & Unit $\mathbf{F}$ & Unit G & Unit $\mathbf{H}$ \\
\hline Depth to top of unit (SLD) & -161 & -------- & ------- \\
\hline Thickness of unit (feet) & 83 & -------1 & -------- \\
\hline Unit's total sand thickness (feet/percent) & $36 / 43$ & -------- & -------- \\
\hline Unit's total shale thickness (feet/percent) -- & $47 / 57$ & -------- & -------- \\
\hline Unit's sand-shale ratio & 0.8 & -------- & --------- \\
\hline Number of potential reservoir sands in unit & 0 & --------- & -------- \\
\hline Total thickness (feet) of unit's potential reservoir sands & --------- & -------- & $-\cdots----$ \\
\hline Average thickness (feet) of unit's potential reservoir sands & --------- & ------- & --- \\
\hline Maximum thickness (feet) of a potential reservoir sand laver in unit & ------- & --------- & ------- \\
\hline Ratio-unit's potential reservoir sand thickness: unit's total thickness & -------- & ---------- & ------ \\
\hline Ratio--unit's potential reservoir sand thickness: unit's total sand thickness & -------- & -------- & -------- \\
\hline $\begin{array}{l}\text { Thickness (feet) -Immediatelv underlying shale seal-potential reservoir sand- } \\
\text { immediately overlying shale seal. }\end{array}$ & $-\cdots-----$ & & \\
\hline $\begin{array}{l}\text { Ratio (feet) -Thickness of immediately underlying shale seal:thickness of } \\
\text { potential reservoir sand:thickness of immediately overlying shale seal. }\end{array}$ & - & & \\
\hline Depth to top of uppermost potential reservoir sand (SLD) & ----- & --------- & -------- \\
\hline Depth to top of lowermost potential reservoir sand (SLD) & --------- & -------- & --- \\
\hline Average depth to top of unit's potential reservoir sand (SLD) & -------- & --------- & -------- \\
\hline Percent of potential reservoir sand in upper third of unit & -------- & -------- & -------- \\
\hline $\begin{array}{l}\text { Percent of potential reservoir sand in middle third of unit } \\
\text { Percent of potential reservoir sand in lower third of unit }\end{array}$ & $----1--1$ & $---1--1-4$ & ------ \\
\hline $\begin{array}{l}\mathrm{D} / \mathrm{PR} \text { factor (average depth of potential reservoir sand occurrence/total thick- } \\
\text { ness of unit's potential reservoir sand). }\end{array}$ & None & ---- & \\
\hline
\end{tabular}


Well No.: NC-CAM-OT-10

Record No.: 1234

State: North Carolina

County: Camden
Well name: E. F. Blair, Weyerhouser No. 1 Latitude: 362440 Longitude: 0761030

Depth of well-_._t

Depth of well (SLD) -...ft-.-.3,725

Elevation of measuring point above ground level...--ft_..-_8

Elevation of ground level_.-_-ft...-.8

Depth to top of unit (SLD)

Unit's total sand thickness (feet/percent)

Unit's total shale thickness (feet/percent)

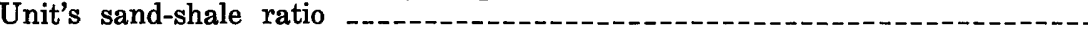

Number of potential reservoir sands in unit

Total thickness (feet) of unit's potential reservoir sands

Average thickness (feet) of unit's potential reservoir sands

Maximum thickness (feet) of a potential reservoir sand layer in unit -

Ratio-unit's potential reservoir sand thickness:unit's total thickness _.......

Ratio-unit's potential reservoir sand thickness: unit's total sand thickness ---

Thickness (feet) - Immediately underlying shale seal-potential reservoir sandimmediately overlying shale seal.

Ratio (feet)-Thickness of immediately underlying shale seal:thickness of potential reservoir sand:thickness of immediately overlying shale seal.

Depth to top of uppermost potential reservoir sand (SLD)

Depth to top of lowermost potential reservoir sand (SLD)

Average depth to top of unit's potential reservoir sand (SLD)

Percent of potential reservoir sand in upper third of unit

Percent of potential reservoir sand in middle third of unit

Percent of potential reservoir sand in lower third of unit

$\mathrm{D} / \mathrm{PR}$ factor (average depth of potential reservoir sand occurrence/total thickness of unit's potential reservoir sand).

Geophysical logs: Electric, Gamma

Well No.: NC-CUR-OT-12

Record No.: 1240

State: North Carolina

County: Currituck

Well name: E, F. Blair \& Assoc, Twiford No. 1

Latitude: 361810

Longitude: 0755530

Depth of well

Depth of well (SLD)

Elevation of measuring point above ground level .... $\mathrm{ft} \ldots . . .7$

Elevation of ground level.

\begin{tabular}{|c|c|c|c|}
\hline Potential reservoir sand determination & Unit $F$ & Unit $G$ & Unit $\mathrm{H}$ \\
\hline $\begin{array}{l}\text { Depth to top of unit (SLD) } \\
\text { Thickness of unit (feet) } \\
\text { Unit's total sand thickness (feet/percent) } \\
\text { Unit's total shale thickness (feet/percent) } \\
\text { Unit's sand-shale ratio } \\
\text { Number of potential reservoir sands in unit } \\
\text { Total thickness (feet) of unit's notential reservoir sands } \\
\text { Average thickness (feet) of unit's potential reservoir sands } \\
\text { Maximum thickness (feet) of a potential reservoir sand laver in unit } \\
\text { Ratio-unit's potential reservoir sand thickness:unit's total thickness } \\
\text { Ratio-unit's potential reservoir sand thickness:unit's total sand thickness } \\
\text { Thickness (feet) -Immediately underlying shale seal-potential reservoir sand- } \\
\text { immediately overlying shale seal. }\end{array}$ & $\begin{array}{l}-1,918 \\
1,105 \\
535 / 48 \\
570 / 52 \\
0.9 \\
7 \\
223 \\
32 \\
40 \\
0.20 \\
0.42 \\
30-40-20 \\
20-30-30 \\
30-40-25 \\
35-35-50\end{array}$ & $\begin{array}{c}-3,023 \\
975 \\
272 / 28 \\
683 / 70 \\
0.4 \\
4 \\
130 \\
33 \\
45 \\
0.13 \\
0.48 \\
20-35-70 \\
54-30-350 \\
350-45-25 \\
25-20-80\end{array}$ & $\begin{array}{c}-3,998 \\
518 \\
158 / 30 \\
300 / 58 \\
0.5 \\
3 \\
70 \\
23 \\
25 \\
0.14 \\
0.44 \\
60-25-20 \\
70-20-35 \\
35-25-30\end{array}$ \\
\hline
\end{tabular}

Ratio (feet)-Thickness of immediately underlying shale seal:thickness of potential reservoir sand:thickness of immediately overlying shale seal.

\begin{tabular}{ccr} 
Unit F & Unit G & Unit H \\
\hline$-1,324$ & $-2,226$ & $-2,602$ \\
902 & 376 & 212 \\
$405 / 45$ & $160 / 43$ & $40 /$ \\
$497 / 55$ & $216 / 57$ & $172 / 8$ \\
0.8 & 0.8 & 0. \\
5 & 1 & 1 \\
138 & 20 & 20 \\
28 & 20 & 20 \\
35 & 20 & 20 \\
9.15 & 0.05 & 0.09 \\
0.34 & 0.13 & 0.50 \\
$35-23-65$ & $40-20-50$ & $60-20$ \\
$65-30-40$ & & \\
$40-30-85$ & & \\
$35-20-30$ & & \\
$20-35-45$ & & \\
$1.52: 1: 2.83$ & $2.00: 1: 2.50$ & $3.00: 1:$ \\
$2.17: 1: 1.33$ & & \\
$1.33: 1: 2.83$ & & \\
$1.75: 1: 1.50$ & & 0 \\
$0.57: 1: 1.29$ & & 0 \\
1,324 & 2,494 & 2,714 \\
2,099 & 2,494 & 2,714 \\
1,763 & 2,494 & 2,714 \\
25 & 0 & 0 \\
14 & 100 & 100 \\
61 & 125 &
\end{tabular}

80-30-40

40-20-20

0.75:1:0.50

$0.67: 1: 1.00$

$0.57: 1: 2.00$

$1.00: 1: 1.43$

$1.80: 1: 11.67$

1.25:1: 4.00

2.40:1:0.80

$3.50: 1: 1.75$

$1.40: 1: 1.20$

2.67:1:1.33

2.00:1:1.00 
Well No.: NC-GUR-OT-12-Continued

\begin{tabular}{|c|c|c|c|}
\hline Potential reservoir sand determination-Continued & Unit $\mathbf{F}$ & Unit $\mathbf{G}$ & Unit $\mathbf{H}$ \\
\hline $\begin{array}{l}\text { Depth to top of uppermost potential reservoir sand (SLD) } \\
\text { Depth to top of lowermost potential reservoir sand (SLD) } \\
\text { Average depth to top of unit's potential reservoir sand (SLD) } \\
\text { Percent of potential reservoir sand in upper third of unit } \\
\text { Percent of potential reservoir sand in middle third of unit } \\
\text { Percent of potential reservoir sand in lower third of unit } \\
\text { D/PR factor (average depth of potential reservoir sand occurrence/total thick- } \\
\quad \text { ness of unit's potential reservoir sand). }\end{array}$ & $\begin{array}{r}2,108 \\
2,868 \\
2,486 \\
22 \\
28 \\
50 \\
11\end{array}$ & $\begin{array}{r}3,358 \\
3,968 \\
3,628 \\
0 \\
50 \\
50 \\
\mathbf{2 8}\end{array}$ & $\begin{array}{r}4,148 \\
4,323 \\
4,226 \\
36 \\
28 \\
36 \\
60\end{array}$ \\
\hline
\end{tabular}

Geophysical logs: Electric, Gamma

Well No.: NC-ON-OT-32

Record No.: 1247

State: North Carolina

County: Onslow
Well name: Colonial Oil \& Gas, No. 1 Parker

Latitude: 344540

Longitude: 0771135

Depth of well-_-ft $\mathrm{t}_{--2,009}$

Depth of well (SLD) _._. ft_-_-1,972

Elevation of measuring point above ground level _....ft_...-7

Elevation of ground level_..._ft_... 30

\begin{tabular}{|c|c|c|c|}
\hline Potential reservoir sand determination & Unit $\mathrm{F}$ & Unit $\mathbf{G}$ & Unit $\mathrm{H}$ \\
\hline Depth to top of unit (SLD) & $-1,520$ & Absent & Absent \\
\hline Thickness of unit (feet) & 255 & 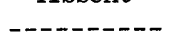 & 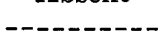 \\
\hline Unit's total sand thickness (feet/percent) & $52 / 20$ & - & - \\
\hline Unit's total shale thickness (feet/percent) & $203 / 80$ & 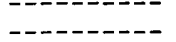 & 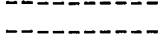 \\
\hline Unit's sand-shale ratio & 0.3 & -1-.-.-- & $--1-.-1-$ \\
\hline Number of potential reservoir sands in unit & 0 & - & - \\
\hline Total thickness (feet) of unit's potential reservoir sands & - & 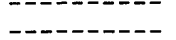 & 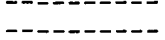 \\
\hline Average thickness (feet) of unit's potential reservoir sands & & & \\
\hline Maximum thickness (feet) of a potential reservoir sand layer in unit & 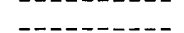 & $-1-1-1$ & $-\ldots-\ldots$ \\
\hline Ratio-unit's potential reservoir sand thickness: unit's total thickness & -....-...- & -..-.....- & -....-..-- \\
\hline Ratio-unit's potential reservoir sand thickness: unit's total sand thickness & & - - - - - - - & \\
\hline $\begin{array}{l}\text { Thickness (feet) - Immediately underlying shale seal-potential reservoir sand- } \\
\text { immediately overlying shale seal. }\end{array}$ & & --1 & \\
\hline $\begin{array}{l}\text { Ratio (feet) - Thickness of immediately underlying shale seal:thickness of } \\
\text { potential reservoir sand:thickness of immediately overlying shale seal. }\end{array}$ & & & \\
\hline Depth to top of uppermost potential reservoir sand (SLD) & -.- & 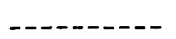 & \\
\hline Depth to top of lowermost potential reservoir sand (SLD) & & & \\
\hline Average depth to top of unit's potential reservoir sand (SLD) & 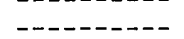 & 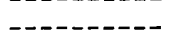 & ----- \\
\hline Percent of potential reservoir sand in upper third of unit & -.. & & \\
\hline Percent of potential reservoir sand in middle third of unit & & & \\
\hline Percent of potential reservoir sand in lower third of unit & 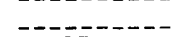 & -------- & ----- \\
\hline $\begin{array}{l}\text { D/PR factor (average depth of potential reservoir sand occurrence/total thick- } \\
\text { ness of unit's potential reservoir sand). }\end{array}$ & None & & \\
\hline
\end{tabular}

Geophysical logs: Electric, Gamma Ray-Density

Well No.: NC-DA-OT-16

Record No.: 1248

Well name: Rapp Oil Co., Laverne Twiford No. 1 Latitude: 354200

State: North Carolina

Longitude: 0754636

Depth of well _._ft $\mathrm{ft}_{\ldots-1} 5,940$

Depth of well (SLD)

Elevation of measuring point above ground level__ $\mathrm{ft}_{\ldots} \ldots$

Elevation of measuring point above ground level__._. $\mathrm{ft}_{\text {. }} \ldots$

\begin{tabular}{|c|c|c|c|}
\hline Potential reservoir sand determination & Unit $\mathbf{F}$ & Unit $\mathbf{G}$ & Unit $\mathbf{H}$ \\
\hline Depth to top of unit (SLD) & $-3,351$ & $-4,193$ & $-\mathbf{5 , 5 1 5}$ \\
\hline Thickness of unit (feet) & 842 & 1,322 & \\
\hline Unit's total sand thickness (feet/percent) & $528 / 63$ & $424 / 32$ & ----- \\
\hline Unit's total shale thickness (feet/percent) & $280 / 33$ & $650 / 49$ & ----- \\
\hline Unit's sand-shale ratio & 1.9 & 0.6 & -------- \\
\hline Number of potential reservoir sands in unit & 3 & 3 & - - - - - - - - \\
\hline Total thickness (feet) of unit's potential reservoir sands & 165 & 131 & ---- \\
\hline Average thickness (feet) of unit's potential reservoir sands & 55 & 44 & ------ \\
\hline Maximum thickness (feet) of a potential reservoir sand laver in unit & 90 & 50 & - - - - - - - - n \\
\hline Ratio-unit's potential reservoir sand thickness:unit's total thickness & 0.20 & 0.12 & $--n------$ \\
\hline Ratio-unit's potential reservoir sand thickness: unit's total sand thickness & 0.31 & 0.33 & --------- \\
\hline \multirow{3}{*}{$\begin{array}{l}\text { Thickness (feet) - Immediatelv underlying shale seal-potential reservoir sand- } \\
\text { immediately overlying shale seal. }\end{array}$} & $43-45-66$ & $50-50-43$ & \\
\hline & $66-30-24$ & $34-38-50$ & \\
\hline & & & \\
\hline
\end{tabular}


Well No.: NC-DA-OT-16-Continued

\begin{tabular}{|c|c|c|c|}
\hline Potential reservoir sand determination-Continued & Unit $\mathbf{F}$ & Unit G & Unit $\mathbf{H}$ \\
\hline $\begin{array}{l}\text { Ratio (feet)-Thickness of immediately underlying shale seal:thickness of } \\
\text { potential reservoir sand:thickness of immediately overlying shale seal. }\end{array}$ & $\begin{array}{l}0.96: 1: 1.47 \\
2.20: 1: 0.80 \\
0.50: 1: 0.43\end{array}$ & $\begin{array}{l}1.00: 1: 0.86 \\
0.89: 1: 1.30 \\
1.50: 1: 1.00\end{array}$ & \\
\hline Depth to top of uppermost potential reservoir sand (SLD) & $\mathbf{3}, \mathbf{3 5 1}$ & 4,237 & 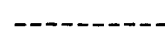 \\
\hline $\begin{array}{l}\text { Depth to top of lowermost potential reservoir sand (SLD) } \\
\text { Average depth to top of unit's potential reservoir sand (SLD) }\end{array}$ & $\begin{array}{l}4,149 \\
3,850\end{array}$ & $\begin{array}{l}4,747 \\
4,440\end{array}$ & \\
\hline Percent of potential reservoir sand in upper third of unit & 55 & 67 & \\
\hline Percent of potential reservoir sand in middle third of unit & 0 & 33 & \\
\hline Percent of potential reservoir sand in lower third of unit & 45 & $\mathbf{0}$ & 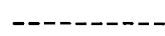 \\
\hline $\begin{array}{l}\text { D/PR factor (average depth of potential reservoir sand occurrence/total thick- } \\
\text { ness of unit's potential reservoir sand). }\end{array}$ & 23 & 34 & \\
\hline
\end{tabular}

Geophysical logs: Electric, Gamma

Well No.: NC-DA-OT-15

Record No.: 1249

State: North Carolina

County: Dare

Well name: Rapp Oil Co., Ethridge No. 1

Latitude: 355600

Longitude: 0754135

Depth of well_-_ $\mathrm{ft}_{\text {- }}--6,049$

Depth of well (SLD)

Elevation of measuring point above ground level_._-_ft_-_._10

Elevation of ground level_....ft_.._.16

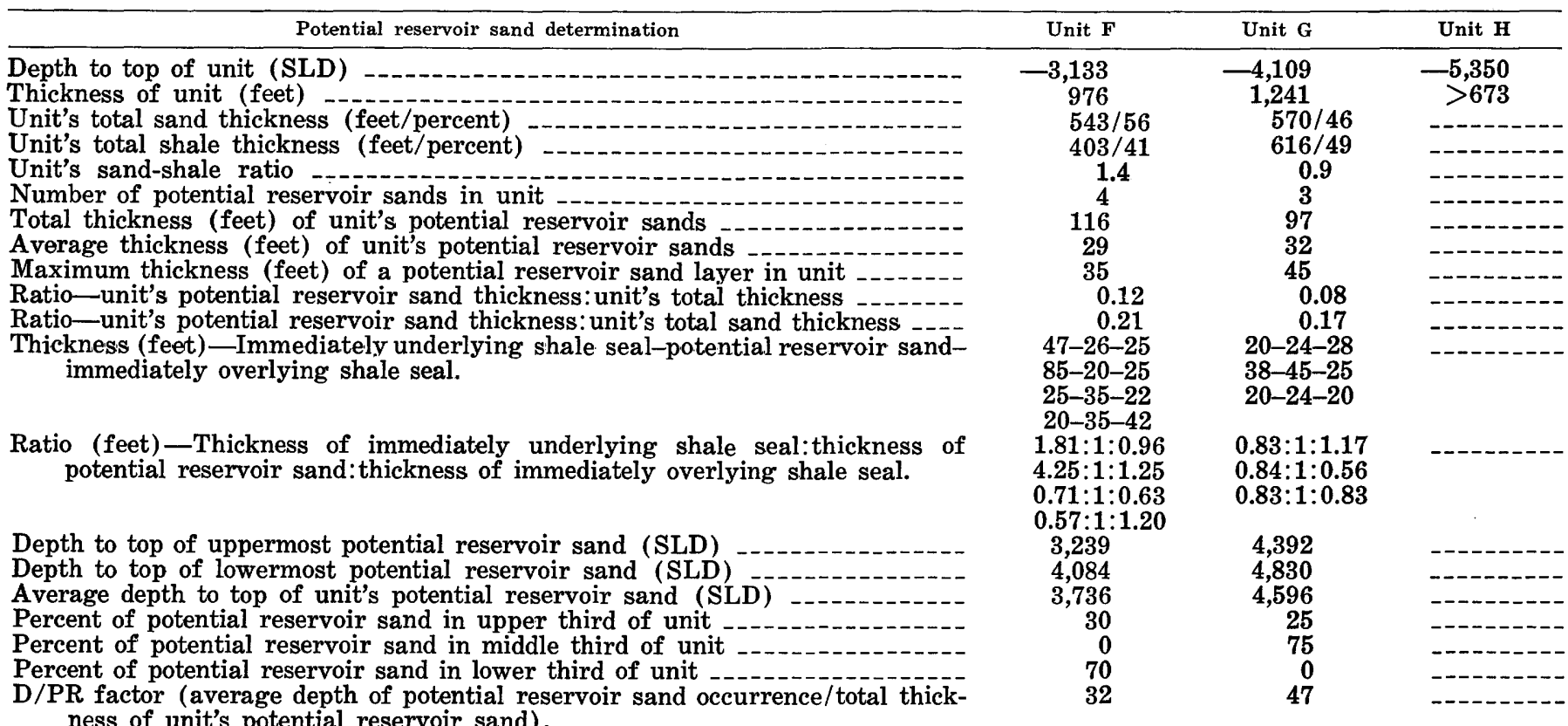
ness of unit's potential reservoir sand).

Geophysical logs: Electric, Gamma

Well No.: NC-GUR-OT-13

Record No.: 1250

State: North Carolina

County: Currituck
Well name: Rapp Oil Co., Kellogg No. 1

Latitude: 360645

Longitude: 0755050

Depth of well-_- $\mathrm{ft}_{\text {th }}-5,118$

Depth of well (SLD) - - ft

Elevation of measuring point above ground level_..._ft..._-7

Elevation of ground level.....ft_...-10

\begin{tabular}{|c|c|c|c|}
\hline Potential reservoir sand determination & Unit $\mathbf{F}$ & Unit G & Unit $\mathbf{H}$ \\
\hline $\begin{array}{l}\text { Depth to top of unit (SLD) } \\
\text { Thickness of unit (feet) } \\
\text { Unit's total sand thickness (feet/percent) } \\
\text { Unit's total shale thickness (feet/percent) } \\
\text { Unit's sand-shale ratio } \\
\text { Number of potential reservoir sands in unit } \\
\text { Total thickness (feet) of unit's potential reservoir sands } \\
\text { Average thickness (feet) of unit's potential reservoir sands }\end{array}$ & $\begin{array}{l}-2,334 \\
1,129 \\
391 / 35 \\
693 / 61 \\
0.6 \\
3 \\
120 \\
40\end{array}$ & $\begin{array}{l}-3,463 \\
1,105 \\
308 / 28 \\
731 / 66 \\
0.4 \\
4 \\
130 \\
30\end{array}$ & $\begin{array}{c}-4,568 \\
487 \\
132 / 27 \\
300 / 62 \\
0.4 \\
1 \\
20 \\
20\end{array}$ \\
\hline
\end{tabular}


Well No: NC-GUR-OT-13-Continued

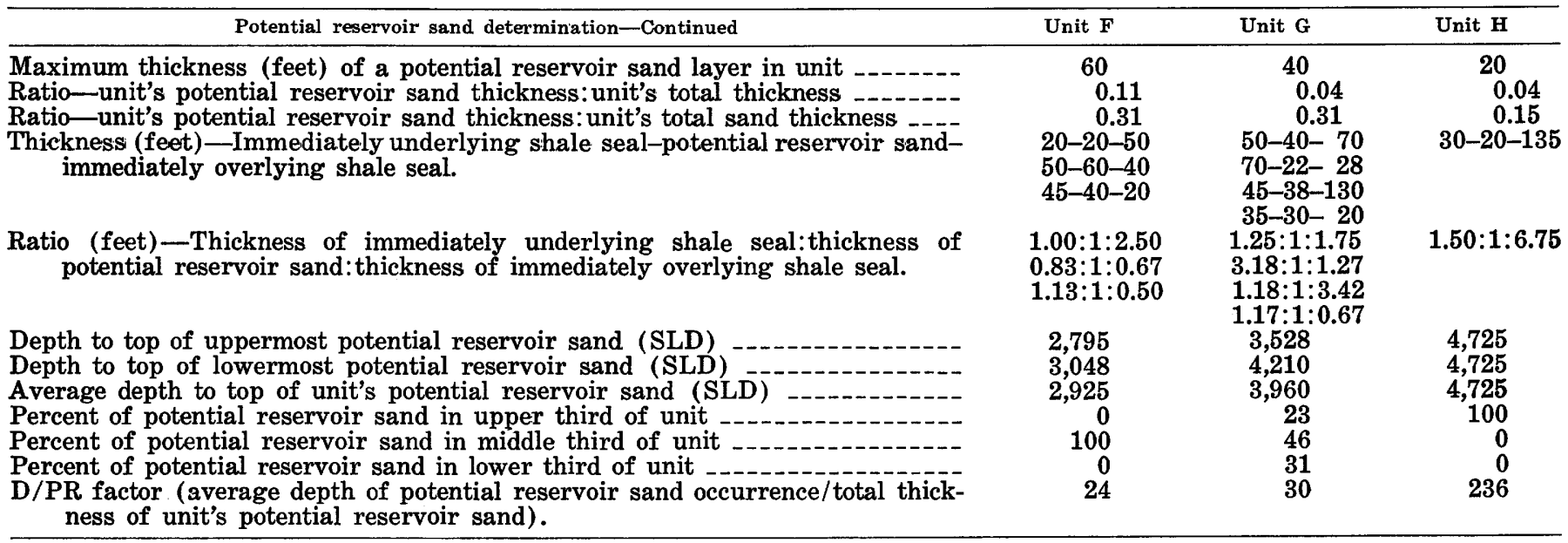

Geophysical logs: Electric, Gamma, Sonic

Well No.: NC-GA-OT-15

Record No.: 1251

Well name: Cullinan-Weyerhauser No. 1

State: North Carolina

Latitude: 362610

County: Gates

Longitude: 0763005

Depth of well-_-_ft--- 2,138

Depth of well (SLD) _._._ft_._-_2,112

Elevation of measuring point above ground level _.... $\mathrm{ft}$

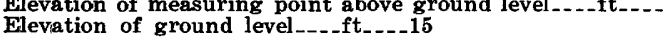

\begin{tabular}{|c|c|c|c|}
\hline Potential reservoir sand determination & Unit $\mathbf{F}$ & Unit G & Jnit $\mathbf{H}$ \\
\hline Depth to top of unit (SLD) & -793 & $-1,327$ & $-1,932$ \\
\hline Thickness of unit (feet) & 534 & 605 & 156 \\
\hline Unit's total sand thickness (feet/percent) & $299 / 56$ & $367 / 61$ & $49 / 31$ \\
\hline Unit's total shale thickness (feet/percent) & $235 / 44$ & $238 / 39$ & $107 / 69$ \\
\hline Unit's sand-shale ratio & 1.3 & 1.5 & 0.5 \\
\hline Number of potential reservoir sands in unit & 1 & 2 & 1 \\
\hline Total thickness (feet) of unit's potential reservoir sands & 37 & 67 & 32 \\
\hline Average thickness (feet) of unit's potential reservoir sands & 37 & 34 & 32 \\
\hline Maximum thickness (feet) of a potential reservoir sand layer in unit & 37 & 40 & 32 \\
\hline Ratio-unit's potential reservoir sand thickness:unit's total thickness & 0.07 & 0.11 & 0.21 \\
\hline Ratio-unit's potential reservoir sand thickness: unit's total sand thickness & 0.12 & 0.18 & 0.65 \\
\hline $\begin{array}{l}\text { Thickness (feet) - Immediately underlying shale seal-potential reservoir sand- } \\
\text { immediately overlying shale seal. }\end{array}$ & $20-37-37$ & $\begin{array}{l}20-27-30 \\
50-40-50\end{array}$ & 20-32-50 \\
\hline $\begin{array}{l}\text { Ratio (feet) -Thickness of immediately underlying shale seal:thickness of } \\
\text { potential reservoir sand:thickness of immediately overlying shale seal. }\end{array}$ & $0.54: 1: 1.00$ & $\begin{array}{l}0.74: 1: 1.00 \\
1.25: 1: 1.25\end{array}$ & $0.63: 1: 1.56$ \\
\hline Depth to top of uppermost potential reservoir sand (SLD) & 1,004 & 1,749 & 1,986 \\
\hline Depth to top of lowermost potential reservoir sand (SLD) & 1,004 & 1,894 & 1,986 \\
\hline Average depth to top of unit's potential reservoir sand (SLD) & 1,004 & 1,827 & 1,986 \\
\hline Percent of potential reservoir sand in upper third of unit & 0 & 0 & 0 \\
\hline Percent of potential reservoir sand in middle third of unit & 100 & 0 & 100 \\
\hline Percent of potential reservoir sand in lower third of unit & 0 & 100 & 0 \\
\hline $\mathrm{D} / \mathrm{PR}$ factor (average depth of potential reservoir sand & 27 & 27 & 32 \\
\hline
\end{tabular}
ness of unit's potential reservoir sand).

Geophysical logs: Electric

Well No.: NC-DA-OT-18

Record No.: 1344

Well name: Citgo, No. 2 Westvaco

State: North Carolina

Latitude: 355230

Longitude: 0755230

Depth of well_._.ft_._. 5,817

Depth of well (SLD) _._.ft___ 5,794

Flevation of mesuring point above ground level _ $\mathrm{ft}$

Elevation of measuring point above $\mathrm{g}$

\begin{tabular}{|c|c|c|c|}
\hline Potential reservoir sand determination & Unit $F$ & Unit $\mathrm{G}$ & Unit $\mathbf{H}$ \\
\hline $\begin{array}{l}\text { Depth to top of unit (SLD) } \\
\text { Thickness of unit (feet) } \\
\text { Unit's total sand thickness (feet/percent) } \\
\text { Unit's total shale thickness (feet/percent) } \\
\text { Unit's sand-shale ratio }\end{array}$ & $\begin{array}{c}-2,745 \\
1,077 \\
621 / 57 \\
387 / 36 \\
1.6\end{array}$ & $\begin{array}{l}-3,822 \\
1,170 \\
357 / 31 \\
728 / 62 \\
0.5\end{array}$ & $\begin{array}{l}-4,982 \\
425 \\
142 / 33 \\
237 / 56 \\
0.6\end{array}$ \\
\hline
\end{tabular}

Unit's sand-shale ratio

1.6 
Well No.: NC-DA-OT-18-Continued

\begin{tabular}{|c|c|c|c|}
\hline Potential reservoir sand determination-Continued & Unit $\mathbf{F}$ & Unit G & Unit $\mathrm{H}$ \\
\hline Number of potential reservoir sands in unit & 4 & 1 & 0 \\
\hline Total thickness (feet) of unit's potential reservoir sands & 186 & 60 & -------- \\
\hline Average thickness (feet) of unit's potential reservoir sands & 47 & 60 & --------- \\
\hline Maximum thickness (feet) of a potential reservoir sand layer in unit & 78 & 60 & 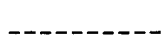 \\
\hline Ratio-unit's potential reservoir sand thickness:unit's total thickness & 0.17 & 0.05 & ------- \\
\hline Ratio_unit's potential reservoir sand thickness:unit's total sand thickness & 0.30 & 0.17 & 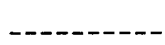 \\
\hline $\begin{array}{l}\text { Thickness (feet) - Immediately underlying shale seal-potential reservoir sand- } \\
\text { immediately overlying shale seal. }\end{array}$ & $\begin{array}{l}30-20-25 \\
48-50-26 \\
20-38-34 \\
20-78-30\end{array}$ & $30-60-20$ &.------- \\
\hline $\begin{array}{l}\text { Ratio (feet)-Thickness of immediately underlying shale seal:thickness of } \\
\text { potential reservoir sand:thickness of immediately overlying shale seal. }\end{array}$ & $\begin{array}{l}1.50: 1: 1.25 \\
0.96: 1: 0.52 \\
0.53: 1: 0.89 \\
0.26: 1: 0.38\end{array}$ & $0.50: 1: 0.33$ & -------- \\
\hline Depth to top of uppermost potential reservoir sand (SLD) & 2,997 & 4,847 & -------- \\
\hline Depth to top of lowermost potential reservoir sand (SLD) & 3,647 & 4,847 & -------- \\
\hline Average depth to top of unit's potential reservoir sand (SLD) & 3,340 & 4,847 & ------- \\
\hline Percent of potential reservoir sand in upper third of unit & 42 & $\mathbf{0}$ & -------- \\
\hline Percent of potential reservoir sand in middle third of unit & 20 & $\mathbf{0}$ & -------1 \\
\hline Percent of potential reservoir sand in lower third of unit & 38 & 100 & --------- \\
\hline $\begin{array}{l}\text { D/PR factor (average depth of potential reservoir sand occurrence/total thick- } \\
\text { ness of unit's potential reservoir sand). }\end{array}$ & 18 & 81 & None \\
\hline
\end{tabular}

Geophysical logs: Electric

Well No.: NC-DA-OT-17

Record No.: 1364

Well name: Citgo, No. 1 Westvaco

State: North Carolina

Latitude: 353936

County: Dare

Longitude: 0754640

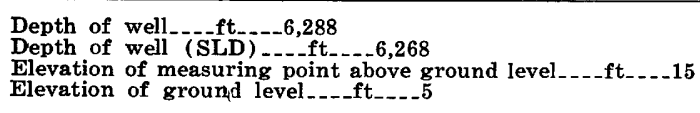

Potential reservoir sand determination

Depth to top of unit (SLD)

Thickness of unit (feet)

Unit's total sand thickness (feet/percent)

Unit's total shale thickness (feet/percent)

Unit's sand-shale ratio

Number of potential reservoir sands in unit

Total thickness (feet) of unit's potential reservoir sands

Average thickness (feet) of unit's potential reservoir sands

Maximum thickness (feet) of a potential reservoir sand layer in unit

Ratio-unit's potential reservoir sand thickness:unit's total thickness

Ratio-unit's potential reservoir sand thickness:unit's total sand thickness

Thickness (feet) - Immediately underlying shale seal-potential reservoir sandimmediately overlying shale seal.

Ratio (feet) - Thickness of immediately underlying shale seal:thickness of potential reservoir sand:thickness of immediately overlying shale seal.

Depth to top of uppermost potential reservoir sand (SLD)

Depth to top of lowermost potential reservoir sand (SLD)

Average depth to top of unit's potential reservoir sand (SLD)

Percent of potential reservoir sand in upper third of unit

Percent of potential reservoir sand in middle third of unit

Percent of potential reservoir sand in lower third of unit

$\mathrm{D} / \mathrm{PR}$ factor (average depth of potential reservoir sand occurrence/total thickness of unit's potential reservoir sand).

\begin{tabular}{|c|c|c|}
\hline Unit $F$ & Unit $G$ & Unit $H$ \\
\hline$-3,440$ & $-4,275$ & $-5,520$ \\
\hline 835 & 1,245 & 588 \\
\hline $424 / 51$ & $360 / 29$ & $218 / 37$ \\
\hline $374 / 45$ & $805 / 65$ & $340 / 58$ \\
\hline 1.1 & 0.5 & 0.6 \\
\hline 0 & 1 & 0 \\
\hline$---\cdots-n---1$ & 41 & ---------- \\
\hline - - - - - & 41 & -------- \\
\hline ----------- & 41 & --- - - - \\
\hline--------- & 0.03 & - - - - - - - - \\
\hline---------- & 0.11 & ---------- \\
\hline - & $55-41-25$ & - \\
\hline$-----1--n$ & $1.30: 1: 0.61$ & \\
\hline - & 4,382 & --- \\
\hline - - - & 4,382 & - - - - - - \\
\hline --------- & 4,382 & ----- - \\
\hline - - - - - - & 100 & ------- \\
\hline --------- & 0 & ------- \\
\hline - - - - - & 0 & - - - - - \\
\hline None & 107 & None \\
\hline
\end{tabular}

Geophysical logs: Electric 
Well No.: NC-TY-OT-1

Record No.: 1368

State: North Carolina

County: Tyrrell
Well name: Exchange Oil and Gas, Westvaco No. 1

Latitude: 3550

Longitude: 07610

Depth of well-_-ft_-_--4,242

Depth of well (SLD)

Elevation of measuring point above ground level_..__ft_.__. 16

Elevation of ground level_._._. $\mathrm{ft}_{\text {-..-.20 }}$

Potential reservoir sand determination

Depth to top of unit (SLD)

Thickness of unit (feet)

) -

Thickness of unit (feet) ----------

Unit's total sand thickness (feet/percent)

Unit's total shale thickness (feet/percent)

Unit's sand-shale ratio

Number of potential reservoir sands in unit

Total thickness (feet) of unit's potential reservoir sands

Average thickness (feet) of unit's potential reservoir sands

Maximum thickness (feet) of a potential reservoir sand layer in unit ......

Ratio-unit's potential reservoir sand thickness:unit's total thickness -

Ratio-unit's potential reservoir sand thickness: unit's total sand thickness - -

Thickness (feet) - Immediately underlying shale seal-potential reservoir sandimmediately overlying shale seal.

Ratio (feet)-Thickness of immediately underlying shale seal:thickness of potential reservoir sand:thickness of immediately overlying shale seal.

Depth to top of uppermost potential reservoir sand (SLD)

Depth to top of lowermost potential reservoir sand (SLD)

Average depth to top of unit's potential reservoir sand (SLD)

Percent of potential reservoir sand in upper third of unit

Percent of potential reservoir sand in middle third of unit

Percent of potential reservoir sand in lower third of unit

$\mathrm{D} / \mathrm{PR}$ factor (average depth of potential reservoir sand occurrence/total thickness of unit's potential reservoir sand).

\begin{tabular}{|c|c|c|}
\hline Unit $F$ & Unit $\mathbf{G}$ & Unit $\mathrm{H}$ \\
\hline$-2,224$ & $-3,084$ & Absent \\
\hline 860 & 980 & ----------- \\
\hline $245 / 28$ & $200 / 20$ & 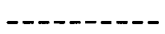 \\
\hline $615 / 72$ & $780 / 80$ & - - \\
\hline 0.4 & 0.3 & - - \\
\hline 1 & 3 & - - - \\
\hline 30 & 115 & - - \\
\hline 30 & 38 & - - \\
\hline 30 & 45 & - - - - \\
\hline 0.03 & 0.12 & - - \\
\hline 0.12 & 0.58 & $---1--$ \\
\hline $50-30-38$ & $\begin{array}{l}75-45-36 \\
32-38-75\end{array}$ & ------ \\
\hline $1.67: 1: 1.27$ & $\begin{array}{c}28-32-22 \\
1.67: 1: 0.80\end{array}$ & $=-$ \\
\hline & $0.84: 1: 1.97$ & \\
\hline & 0.88:1:0.69 & \\
\hline 2,454 & 3,344 & - - - - \\
\hline 2,454 & 4,004 & --------- \\
\hline 2,454 & $\begin{array}{r}3,607 \\
39\end{array}$ & - - - - - - \\
\hline $\begin{array}{r}100 \\
0\end{array}$ & 33 & 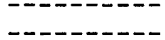 \\
\hline 0 & 28 & - - - - - - \\
\hline 82 & 31 & ---0 \\
\hline
\end{tabular}

Geophysical logs: Electric

Well No.: NC-TY-OT-2

Record No.: 1369

State: North Carolina

County: Tyrrell
Well name: Exchange Oil and Gas, Westvaco No. 2

Latitude: 3555

Longitude: 07610

Depth of well_-_-ft_._- 4,148

Depth of well (SLD) _...ft

Dround level $\mathrm{ft}_{-}$

Elevation of ground level....ft...-12

\begin{tabular}{|c|c|c|c|}
\hline Potential reservoir sand determination & Unit $\mathbf{F}$ & Unit G & Unit $\mathrm{H}$ \\
\hline Depth to top of unit (SLD) & $-2,132$ & $-2,972$ & Absent \\
\hline Thickness of unit (feet) & 840 & 910 & $------1-$ \\
\hline Unit's total sand thickness (feet/percent) & $362 / 43$ & $182 / 20$ & \\
\hline Unit's total shale thickness (feet/percent) & $478 / 57$ & $728 / 80$ & ----- \\
\hline Unit's sand-shale ratio & 0.8 & 0.3 & \\
\hline Number of potential reservoir sands in unit & 1 & 1 & -..--.-- \\
\hline Total thickness (feet) of unit's potential reservoir sands & 56 & 24 & --------- \\
\hline Average thickness (feet) of unit's potential reservoir sands & 56 & 24 & -..-- \\
\hline Maximum thickness (feet) of a potential reservoir sand layer in unit & 56 & 24 & -..--..-. \\
\hline Ratio-unit's potential reservoir sand thickness:unit's total thickness & 0.07 & 0.03 & --.--..- \\
\hline Ratio-unit's potential reservoir sand thickness:unit's total sand thickness & 0.15 & 0.13 & -..-- \\
\hline $\begin{array}{l}\text { Thickness (feet)-Immediately underlying shale seal-potential reservoir sand- } \\
\text { immediately overlying shale seal. }\end{array}$ & $50-56-40$ & $55-24-140$ & \\
\hline $\begin{array}{l}\text { Ratio (feet)-Thickness of immediately underlying shale seal:thickness of } \\
\text { potential reservoir sand:thickness of immediately overlying shale seal. }\end{array}$ & $0.89: 1: 0.71$ & $2.29: 1: 5.83$ & \\
\hline Depth to top of uppermost potential reservoir sand (SLD) & 2,932 & 3,377 & \\
\hline Depth to top of lowermost potential reservoir sand (SLD) & $\overline{2}, 932$ & 3,377 & 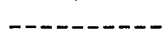 \\
\hline Average depth to top of unit's potential reservoir sand (SLD) & 2,932 & 3,377 & \\
\hline Percent of potential reservoir sand in upper third of unit & 0 & 0 & \\
\hline Percent of potential reservoir sand in middle third of unit & 0 & 100 & \\
\hline Percent of potential reservoir sand in lower third of unit & 100 & 0 & -......- \\
\hline $\mathrm{D} / \mathrm{PR}$ factor (average depth of potential reservoir sand occurrence/total thick- & 52 & 141 & \\
\hline
\end{tabular}

Geophysical logs: Electric 
Well No.: NC-TY-OT-3

Record No.: 1370

State: North Carolina

County: Tyrrell
Well name: Exchange Oil and Gas Corp., Westvaco No. 3

Latitude: 3545

Longitude: 07610

Depth of well-_-_ft_-.-.4,855

Depth of well (SLD) _...ft

Elevation of measuring point above ground level

Elevation of ground level_.....ft_...-10 Potential reservoir sand determination

Depth to top of unit (SLD)

Thickness of unit (feet)

-

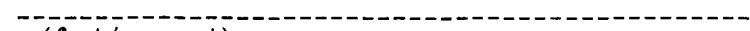

Unit's total sand thickness (feet/percent)

Unit's total shale thickness (feet/percent)

Unit's sand-shale ratio

Number of potential reservoir sands in unit -

Total thickness (feet) of unit's potential reservoir sands

Average thickness (feet) of unit's potential reservoir sands

Maximum thickness (feet) of a potential reservoir sand layer in unit .

Ratio-unit's potential reservoir sand thickness:unit's total thickness -..--..-

Ratio-unit's potential reservoir sand thickness: unit's total sand thickness -- -

Thickness (feet) - Immediately underlying shale seal-potential reservoir sandimmediately overlying shale seal.

Ratio (feet)-Thickness of immediately underlying shale seal:thickness of potential reservoir sand:thickness of immediatelv overlying shale seal.

Depth to top of uppermost potential reservoir sand (SLD)

Depth to top of lowermost potential reservoir sand (SLD)

Average depth to top of unit's potential reservoir sand (SLD)

Percent of potential reservoir sand in upper third of unit

Percent of potential reservoir sand in middle third of unit

Percent of potential reservoir sand in lower third of unit

$\mathrm{D} / \mathrm{PR}$ factor (average depth of potential reservoir sand occurrence/total thickness of unit's potential reservoir sand).

\begin{tabular}{ccc} 
Unit F & Unit G & Unit H \\
\hline$-2,479$ & $-3,414$ & $-4,404$ \\
935 & 990 & 340 \\
$876 / 94$ & $275 / 28$ & $134 / 39$ \\
$59 / 6$ & $715 / 72$ & $206 / 61$ \\
14.8 & 0.4 & 0.7 \\
1 & 2 & 1 \\
37 & 85 & 26 \\
37 & 43 & 26 \\
37 & 60 & 26 \\
0.04 & 0.09 & 0.08 \\
0.04 & 0.31 & 0.19 \\
$34-37-85$ & $40-60-60$ & $65-26-28$ \\
& $110-25-60$ & \\
$0.92: 1: 2.36$ & $0.67: 1: 1.00$ & $2.50: 1: 1.08$ \\
& $4.40: 1: 2.40$ & \\
3,214 & 3,459 & 4,646 \\
3,214 & 4,324 & 4,646 \\
3,214 & 3,892 & 4,646 \\
0 & 29 & 0 \\
0 & 0 & 0 \\
100 & 71 & 100 \\
87 & 46 & 179
\end{tabular}

Geophysical logs: Electric

Well No.: NC-TY-OT-4

Record No.: 1371

State: North Carolina

County: Tyrrell
Well name: Bee Tree-Whitehurst No. 1

Latitude: 354815

Longitude: 0762047

Depth of well - ft
Depth of well (SLD) $-3,564$

Depth of well (SLD) -

Elevation of measuring point above ground level_....ft_..._8

Elevation of ground level _.... $\mathrm{ft}_{\text {. }} \ldots$

\begin{tabular}{|c|c|c|c|}
\hline Potential reservoir sand determination & Unit $F$ & Unit $\mathbf{G}$ & Unit $\mathbf{H}$ \\
\hline Depth to top of unit (SLD) & $-1,992$ & $-2,772$ & Absent \\
\hline Thickness of unit (feet) & 780 & 710 & -------- \\
\hline Unit's total sand thickness (feet/percent) & $262 / 34$ & $200 / 28$ & --------- \\
\hline Unit's total shale thickness (feet/percent) & $518 / 66$ & $510 / 72$ & --------- \\
\hline Unit's sand-shale ratio & 0.5 & 0.4 & ------- \\
\hline Number of potential reservoir sands in unit & 1 & 1 & $-\ldots-\ldots-n$ \\
\hline Total thickness (feet) of unit's potential reservoir sands & 22 & 20 & 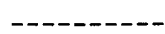 \\
\hline Average thickness (feet) of unit's potential reservoir sands & 22 & 20 & 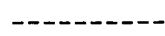 \\
\hline Maximum thickness (feet) of a potential reservoir sand layer in unit & 22 & 20 & $---\ldots-$. \\
\hline Ratio-unit's potential reservoir sand thickness:unit's total thickness & 0.03 & 0.03 & $-\ldots-$. \\
\hline Ratio-unit's potential reservoir sand thickness: unit's total sand thickness & 0.08 & 0.10 & --- \\
\hline $\begin{array}{l}\text { Thickness (feet) - Immediately underlying shale seal-potential reservoir sand- } \\
\text { immediately overlying shale seal. }\end{array}$ & $70-22-40$ & $90-20-38$ & -- \\
\hline $\begin{array}{l}\text { Ratio (feet)-Thickness of immediately underlying shale seal:thickness of } \\
\text { potential reservoir sand:thickness of immediately overlying shale seal. }\end{array}$ & $3.18: 1: 1.81$ & $4.5: 1: 1.90$ & \\
\hline Depth to top of uppermost potential reservoir sand (SLD) & 2,572 & 2,932 & ----- \\
\hline Depth to top of lowermost potential reservoir sand (SLD) & 2,572 & 2,932 & -----1 \\
\hline Average depth to top of unit's potential reservoir sand (SLD) & $\mathbf{2}, 57 \overline{2}$ & 2,932 & ------ \\
\hline Percent of potential reservoir sand in upper third of unit & 0 & 100 & $-\ldots-$. \\
\hline Percent of potential reservoir sand in middle third of unit & 0 & 0 & ------- \\
\hline Percent of potential reservoir sand in lower third of unit & 100 & 0 & ------ \\
\hline $\begin{array}{l}\text { D/PR factor (average depth of potential reservoir sand occurrence/total thick- } \\
\text { ness of unit's potential reservoir sand). }\end{array}$ & 117 & 147 & \\
\hline
\end{tabular}


Well No.: NC-PAS-OT-5

Record No.: 1372

State: North Carolina

County: Pasquotank
Well name: Hoerner Waldorf No. 1

Latitude: 3620

Longitude: 07622

Depth of well

Depth of well (SLD)

Elevation of measuring point above ground level_._._ft_....11

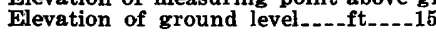

\begin{tabular}{|c|c|c|c|}
\hline Potential reservoir sand determination & Unit $\mathbf{F}$ & Unit $\mathbf{G}$ & Unit $\mathbf{H}$ \\
\hline Depth to top of unit (SLD) & $-1,064$ & $-1,816$ & $-2,436$ \\
\hline Thickness of unit (feet) & 752 & 620 & 160 \\
\hline Unit's total sand thickness (feet/percent) & $330 / 44$ & $260 / 42$ & $0 / 0$ \\
\hline Unit's total shale thickness (feet/percent) & $422 / 56$ & $360 / 58$ & $160 / 100$ \\
\hline Unit's sand-shale ratio & 0.8 & 0.7 & $\mathbf{0}$ \\
\hline Number of potential reservoir sands in unit & 5 & 3 & 0 \\
\hline Total thickness (feet) of unit's potential reservoir sands & 189 & 167 & .....- \\
\hline Average thickness (feet) of unit's potential reservoir sands & 38 & 56 & ----- \\
\hline Maximum thickness (feet) of a potential reservoir sand layer in unit & 70 & 110 & 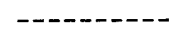 \\
\hline Ratio-unit's potential reservoir sand thickness:unit's total thickness & 0.25 & 0.27 & 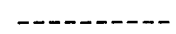 \\
\hline Ratio-unit's potential reservoir sand thickness: unit's total sand thickness & 0.57 & 0.64 & $\ldots$ \\
\hline $\begin{array}{l}\text { Thickness (feet) - Immediately underlying shale seal-potential reservoir sand- } \\
\text { immediately overlying shale seal. }\end{array}$ & $\begin{array}{l}20-22-33 \\
34-45-20 \\
60-70-32 \\
32-30-30 \\
30-22-65\end{array}$ & $\begin{array}{l}60-37-40 \\
50-110-30 \\
45-20-62\end{array}$ & \\
\hline $\begin{array}{l}\text { Ratio (feet)-Thickness of immediately underlying shale seal:thickness of } \\
\text { potential reservoir sand:thickness of immediately overlying shale seal. }\end{array}$ & $\begin{array}{l}0.91: 1: 1.50 \\
0.76: 1: 0.44 \\
0.86: 1: 0.46 \\
1.07: 1: 1.00 \\
1.36: 1: 2.95\end{array}$ & $\begin{array}{l}1.62: 1: 1.08 \\
0.45: 1: 0.27 \\
2.25: 1: 3.10\end{array}$ & \\
\hline Depth to top of uppermost potential reservoir sand (SLD) - & 1,259 & 1,894 & ----- \\
\hline Depth to top of lowermost potential reservoir sand (SLD) & 1,794 & 2,279 & --- \\
\hline Average depth to top of unit's potential reservoir sand (SLD) & 1,467 & 2,286 & \\
\hline Percent of potential reservoir sand in upper third of unit & 35 & 67 & $-\ldots-n-\ldots$ \\
\hline Percent of potential reservoir sand in middle third of unit & 37 & $\mathbf{0}$ & \\
\hline Percent of potential reservoir sand in lower third of unit & 28 & 33 & \\
\hline $\begin{array}{l}\text { D/PR factor (average depth of potential reservoir sand occurrence/total thick- } \\
\text { ness of unit's potential reservoir sand). }\end{array}$ & 8 & 16 & None \\
\hline
\end{tabular}

Geophysical logs: Electric

Well No.: VA-NOR-T-12

Record No.: 2041

Well name: Norfolk USGS Test

Latitude: 365200

County: Norfolk

Longitude: 0761200

Depth of well_.. ft_-_-2,582

Depth of well (SLD) -

levation of measuring point above ground level _... ft_....0

Elevation of ground level

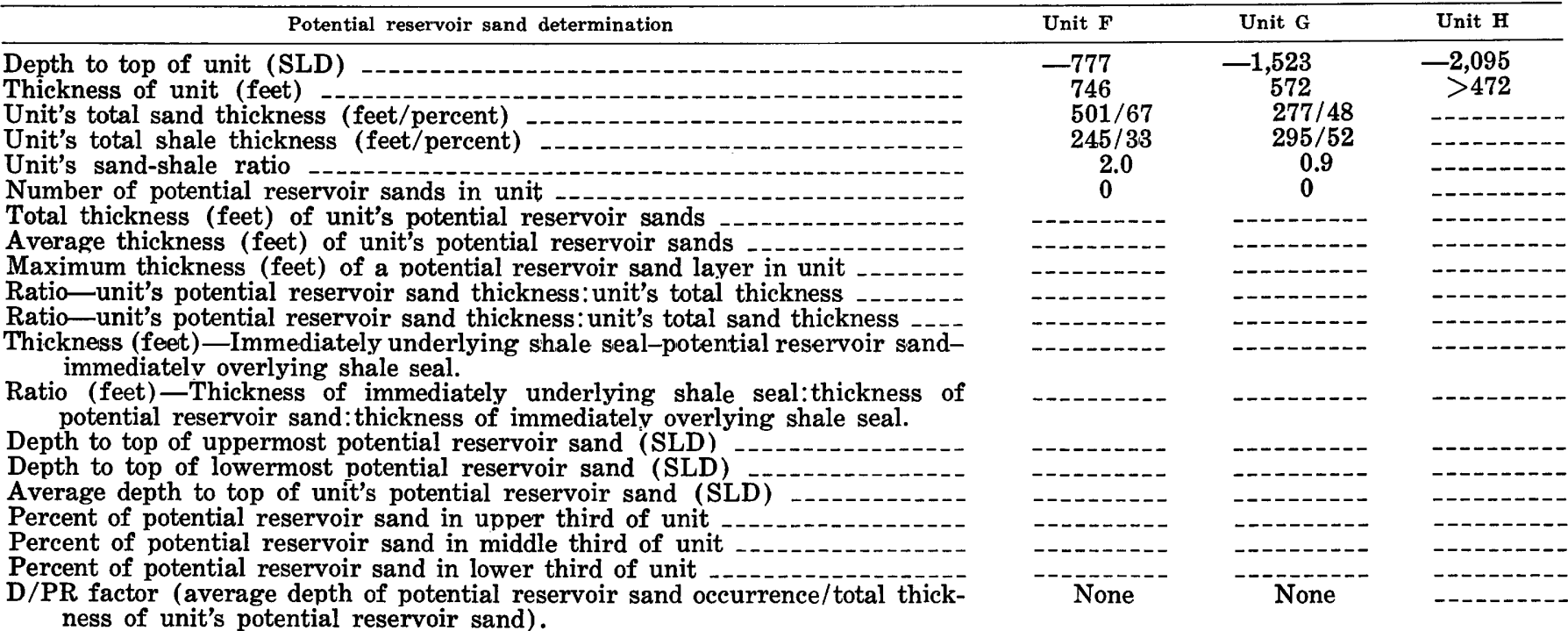


Well No.: VA-JC-T-11

Record No.: 2052

State: Virginia

County: James City

Well name: Dow Chemical, Lee Hall

Latitude: 371140

Longitude: 0763655

Depth of well-.-ft.---1,560

Depth of well (SLD) - $\mathrm{ft}_{\text {- }}-1,540$

Elevation of measuring point above ground level_....ft_....0

Elevation of ground level ..... ft_....20

\begin{tabular}{|c|c|c|c|}
\hline Potential reservoir sand determination & Unit $F$ & Unit $\mathbf{G}$ & Unit $\mathbf{H}$ \\
\hline Depth to top of unit (SLD) & -379 & -964 & $-1,358$ \\
\hline Thickness of unit (feet) & 585 & 394 & \\
\hline Unit's total sand thickness (feet/percent) & $237 / 41$ & $110 / 28$ & \\
\hline Unit's total shale thickness (feet/percent) & $348 / 59$ & $284 / 72$ & \\
\hline Unit's sand-shale ratio & 0.68 & 0.39 & \\
\hline Number of potential reservoir sands in unit & 2 & 0 & \\
\hline Total thickness (feet) of unit's potential reservoir sands & $5 \overline{2}$ & .....- & \\
\hline Average thickness (feet) of unit's potential reservoir sands & 26 & -------- & \\
\hline Maximum thickness (feet) of a potential reservoir sand layer in unit & 30 & 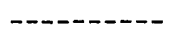 & \\
\hline Ratio-unit's potential reservoir sand thickness:unit's total thickness & 0.09 & --.---.-- & \\
\hline Ratio-unit's potential reservoir sand thickness:unit's total sand thickness & 0.22 & --_--. & \\
\hline $\begin{array}{l}\text { Thickness (feet) - Immediately underlying shale seal-potential reservoir sand- } \\
\text { immediately overlying shale seal. }\end{array}$ & $\begin{array}{l}20-22-66 \\
66-30-55\end{array}$ & --- & \\
\hline Ratio (feet)-Thickness of immediately underlying shale seal:thickness of & $0.91: 1: 3.00$ & & \\
\hline Depth to top of uppermost potential reservoir sand (SLD) & $\begin{array}{l}2.20: 1: 1.83 \\
718\end{array}$ & - - & \\
\hline Depth to top of lowermost potential reservoir sand (SLD) & 836 & & \\
\hline Average depth to top of unit's potential reservoir sand (SLD) & 777 & -...- & \\
\hline Percent of potential reservoir sand in upper third of unit & 0 & 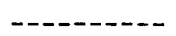 & \\
\hline Percent of potential reservoir sand in middle third of unit & 58 & & \\
\hline Percent of potential reservoir sand in lower third of unit & 42 & & \\
\hline $\begin{array}{l}\text { D/PR factor (average depth of potential reservoir sand occurrence/total thick- } \\
\text { ness of unit's potential reservoir sand). }\end{array}$ & 15 & None & \\
\hline
\end{tabular}

Geophysical logs: Electric, Gamma

Well No.: VA-AC-OT-5

Record No.: 2113

State: Virginia

County: Accomack

Well name: J \& J Enterprises, Taylor No. 1

Latitude: 375303

Longitude: 0753101

Depth of well-_-ft_--6,279

Depth of well (SLD) - ft 6,226

Elevation of measuring point above ground level __ ft

Elevation of ground level $\ldots . . .-\mathrm{ft}$

\begin{tabular}{|c|c|c|c|}
\hline Potential reservoir sand determination & Unit $\mathbf{F}$ & Unit $\mathrm{G}$ & Unit $\mathbf{H}$ \\
\hline Depth to top of unit (SLD) & $-1,559$ & $-2,298$ & $-3,266$ \\
\hline Thickness of unit (feet) & 739 & 968 & 1,810 \\
\hline Unit's total sand thickness (feet/percent) & $240 / 32$ & $452 / 47$ & $573 / 32$ \\
\hline Unit's total shale thickness (feet/percent) & $496 / 68$ & $516 / 53$ & $1,237 / 68$ \\
\hline Unit's sand-shale ratio & 0.5 & 0.9 & 0.5 \\
\hline Number of potential reservoir sands in unit & 0 & 3 & 2 \\
\hline Total thickness (feet) of unit's potential reservoir sands & & 110 & 76 \\
\hline Average thickness (feet) of unit's potential reservoir sands & 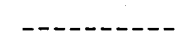 & 37 & 38 \\
\hline Maximum thickness (feet) of a potential reservoir sand laver in unit & - & 60 & 46 \\
\hline Ratio-unit's potential reservoir sand thickness:unit's total thickmess & & 0.10 & 0.04 \\
\hline Ratio-unit's potential reservoir sand thickness: unit's total sand thickness & -.-- & 0.21 & 0.13 \\
\hline $\begin{array}{l}\text { Thickness (feet) - Immediately underlying shale seal-potential reservoir sand- } \\
\text { immediately overlying shale seal. }\end{array}$ & ----- & $\begin{array}{r}24-60-108 \\
108-20-36 \\
50-30-118\end{array}$ & $\begin{array}{l}64-46-50 \\
24-30-25\end{array}$ \\
\hline $\begin{array}{l}\text { Ratio (feet)-Thickness of immediately underlying shale seal:thickness of } \\
\text { potential reservoir sand:thickness of immediately overlying shale seal. }\end{array}$ & & $\begin{array}{l}0.40: 1: 1.80 \\
5.40: 1: 1.80 \\
1.67: 1: 3.93\end{array}$ & $\begin{array}{l}1.39: 1: 1.09 \\
0.80: 1: 0.83\end{array}$ \\
\hline Depth to top of uppermost potential reservoir sand (SLD) & ....- & 2,497 & 4,183 \\
\hline Depth to top of lowermost potential reservoir sand (SLD) & & 3,207 & 4,547 \\
\hline Average depth to top of unit's potential reservoir sand (SLD) & -....... & 2,928 & 4,365 \\
\hline Percent of potential reservoir sand in upper third of unit & & 27 & 0 \\
\hline Percent of potential reservoir sand in middle third of unit & 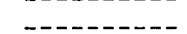 & 0 & 39 \\
\hline Percent of potential reservoir sand in lower third of unit & - - - - n- & 73 & 61 \\
\hline $\begin{array}{l}\mathrm{D} / \mathrm{PR} \text { factor (average depth of potential reservoir sand occurrence/total thick- } \\
\text { ness of unit's potential reservoir sand). }\end{array}$ & None & 27 & 57 \\
\hline
\end{tabular}

Geophysical logs: Electric, Gamma, Sonic 
Record No.: 2115

Well No.: VA-NAN-T-26

State: Virginia

County: Nansemond

Well name: State Obs. Well, Adams Swamp

Latitude: 363410

Longitude: 0763505

Depth of well---ft_--_2,017

Depth of well (SLD) --..ft--.-1,954

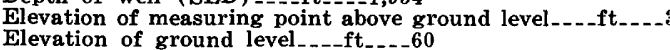

\begin{tabular}{|c|c|c|c|}
\hline Potential reservoir sand determination & Unit $\mathrm{F}$ & Unit G & Unit $\mathbf{H}$ \\
\hline Depth to top of unit (SLD) & -592 & $-1,068$ & $-1,480$ \\
\hline Thickness of unit (feet) & 476 & 412 & 267 \\
\hline Unit's total sand thickness (feet/percent) & $230 / 48$ & $109 / 26$ & $80 / 30$ \\
\hline Unit's total shale thickness (feet/percent) & $246 / 52$ & $303 / 74$ & $187 / 70$ \\
\hline Unit's sand-shale ratio & 0.9 & 0.4 & 0.4 \\
\hline Number of potential reservoir sands in unit & 0 & 0 & 0 \\
\hline Total thickness (feet) of unit's potential reservoir sands & -.-- & -.-- & -- \\
\hline Average thickness (feet) of unit's potential reservoir sands & -.---- & ....- & -- \\
\hline Maximum thickness (feet) of a potential reservoir sand layer in unit & ----- & $-\ldots-n---$ & 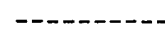 \\
\hline Ratio-unit's potential reservoir sand thickness:unit's total thickness & -....- & --.------ & 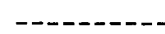 \\
\hline Ratio-unit's potential reservoir sand thickness: unit's total sand thickness & $-\ldots-$. &.-- & $\ldots$ \\
\hline $\begin{array}{l}\text { Thickness (feet)-Immediately underlying shale seal-potential reservoir sand- } \\
\text { immediately overlying shale seal. }\end{array}$ & & & \\
\hline $\begin{array}{l}\text { Ratio (feet)-Thickness of immediately underlying shale seal:thickness of } \\
\text { potential reservoir sand:thickness of immediately overlying shale seal. }\end{array}$ & & & \\
\hline Depth to top of uppermost potential reservoir sand (SLD) & ------ & - & \\
\hline Depth to top of lowermost potential reservoir sand (SLD) & & -9 &.---- \\
\hline Average depth to top of unit's potential reservoir sand (SLD) & - & --1 & \\
\hline Percent of potential reservoir sand in upper third of unit & ------- & ------1 & ----- \\
\hline Percent of potential reservoir sand in middle third of unit & $-\ldots$ & -..- & 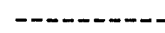 \\
\hline Percent of potential reservoir sand in lower third of unit & & & \\
\hline $\begin{array}{l}\text { D/PR factor (average depth of potential reservoir sand occurrence/total thick- } \\
\text { ness of unit's potential reservoir sand). }\end{array}$ & None & None & None \\
\hline
\end{tabular}

Geophysical logs: Electric, Gamma

Well No.: MD-WIC-OT-11

Record No. 3032

Well name: Ohio Oil Co., Hammond No. 1

State: Maryland

County: Wicomico

Latitude: 381845

Longitude: 0752930

Depth of well__._ft----5,568

Depth of well (SLD)

Elevation of measuring point above ground level_....ft.....16

Elevation of ground level_....ft_....54

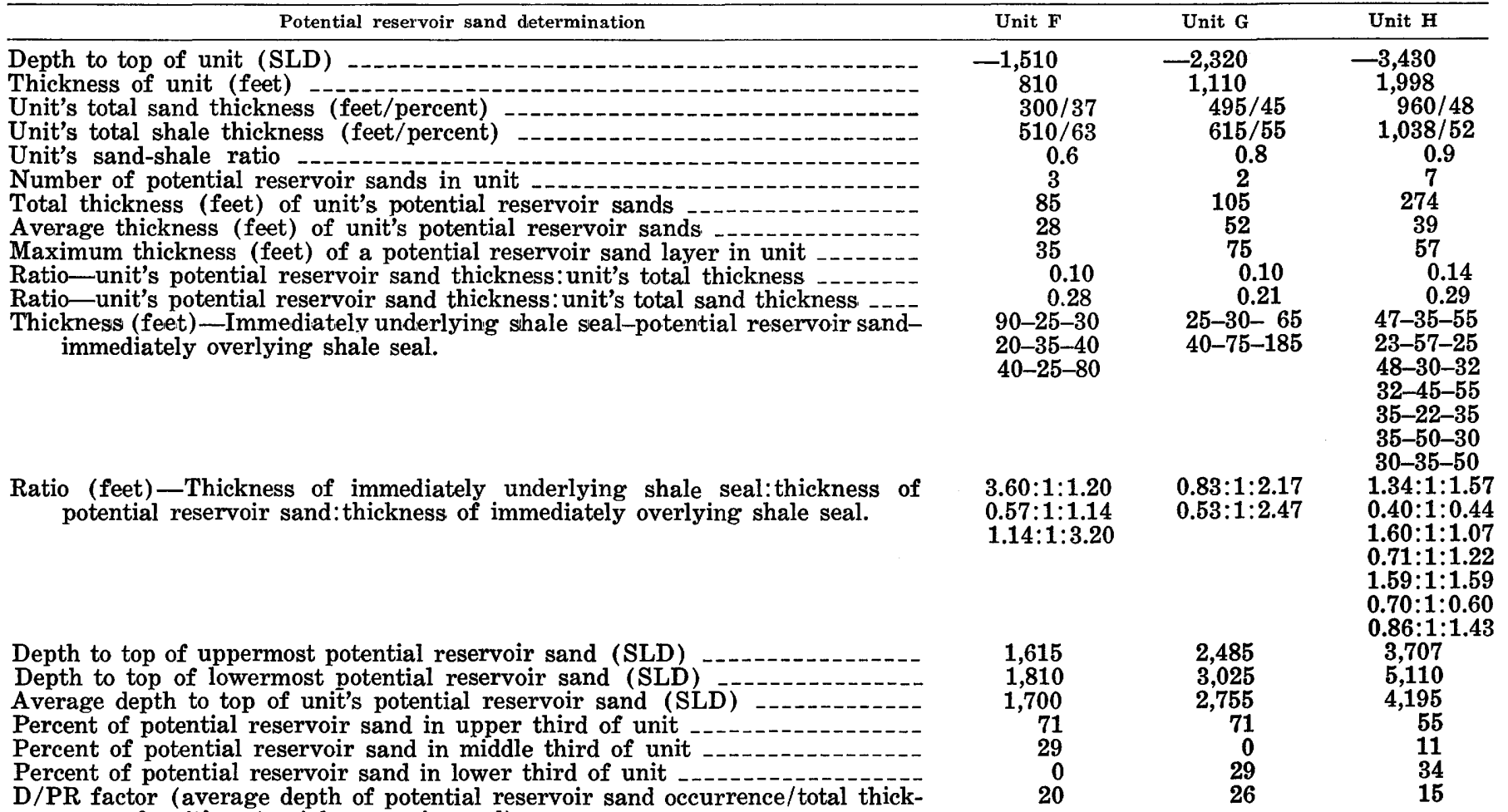

$\mathrm{D} / \mathrm{PR}$ factor (average depth of potential reservoir sand occurrence/total thickness of unit's potential reservoir sand). 
Well No.: MD-WOR-OT-10

Record No.: 3033

State: Maryland

County: Worcester
Well name: Socony-Vacuum Bethard No. 1

Latitude: 381815

Longitude: 0751630

Depth of well

Depth of well (SLD) -...ft-...-7,116

Elevation of measuring point above ground level_....ft_....13

Elevation of ground level.....ft.....45

Potential reservoir sand determination

Depth to top of unit (SLD)

Unit's total sand thickness (feet/percent)

Unit's total shale thickness (feet/percent) -

Unit's sand-shale ratio

Number of potential reservoir sands in unit

Total thickness (feet) of unit's potential reservoir sands

Average thickness (feet) of unit's potential reservoir sands

Maximum thickness (feet) of a potential reservoir sand layer in unit .

Ratio-unit's potential reservoir sand thickness: unit's total thickness -.......

Ratio-unit's potential reservoir sand thickness:unit's total sand thickness -

Thickness (feet) - Immediately underlying shale seal-potential reservoir sandimmediately overlying shale seal.

Ratio (feet)-Thickness of immediately underlying shale seal:thickness of potential reservoir sand:thickness of immediately overlying shale seal.

Depth to top of uppermost potential reservoir sand (SLD)

Depth to top of lowermost potential reservoir sand (SLD)

Average depth to top of unit's potential reservoir sand (SLD)

Percent of potential reservoir sand in upper third of unit

Percent of potential reservoir sand in middle third of unit

Percent of potential reservoir sand in lower third of unit

$\mathrm{D} / \mathrm{PR}$ factor (average depth of potential reservoir sand occurrence/total thickness of unit's potential reservoir sand).

Geophysical logs: Electric

Well No.: MD-WOR-OT-11

Record No.: 3034

State: Maryland

County: Worcester

Well name: Standard Oil of N.J., Maryland Esso No. 1

Latitude: 382430

Longitude: 0750345

Depth of well _...ft_...7,710

Depth of well (SLD)

Elevation of measuring point above ground level_.._-_tt_... 4
Elevation of ground level

\begin{tabular}{|c|c|c|c|}
\hline Potential reservoir sand determination & Unit $\mathbf{F}$ & Unit G & Unit $\mathbf{H}$ \\
\hline $\begin{array}{l}\text { Depth to top of unit (SLD) } \\
\text { Thickness of unit (feet) } \\
\text { Unit's total sand thickness (feet/percent) } \\
\text { Unit's total shale thickness (feet/percent) } \\
\text { Unit's sand-shale ratio } \\
\text { Number of potential reservoir sands in unit } \\
\text { Total thickness (feet) of unit's potential reservoir sands } \\
\text { Average thickness (feet) of unit's potential reservoir sands } \\
\text { Maximum thickness (feet) of a potential reservoir sand layer in unit } \\
\text { Ratio-unit's potential reservoir sand thickness: unit's total thickness } \\
\text { Ratio-unit's potential reservoir sand thickness:unit's total sand thickness } \\
\text { Thickness (feet) - Immediately underlying shale seal-potential reservoir sand- } \\
\text { immediately overlying shale seal. }\end{array}$ & $\begin{array}{c}-2,725 \\
1,212 \\
612 / 51 \\
600 / 49 \\
0.8 \\
7 \\
470 \\
67 \\
185 \\
0.39 \\
0.77 \\
50-25-20 \\
20-50-20 \\
35-60-105 \\
105-20-145 \\
145-105-50 \\
50-185-80 \\
80-95\end{array}$ & $\begin{array}{c}-3,937 \\
1,162 \\
500 / 43 \\
642 / 55 \\
0.8 \\
1 \\
60 \\
60 \\
60 \\
0.05 \\
0.15 \\
20-60-200\end{array}$ & $\begin{array}{c}-5,099 \\
2,072 \\
1,202 / 58 \\
870 / 42 \\
1.4 \\
5 \\
165 \\
33 \\
40 \\
0.08 \\
0.14 \\
35-35-30 \\
30-30-40 \\
40-30-60 \\
35-40-25 \\
95-30-20\end{array}$ \\
\hline
\end{tabular}


Well No.: MD-WOR-OT-11-Continued

\begin{tabular}{|c|c|c|c|}
\hline Potential reservoir sand determination-Continued & Unit $\mathbf{F}$ & Unit $\mathbf{G}$ & Unit $\mathbf{R}$ \\
\hline $\begin{array}{l}\text { Ratio (feet)-Thickness of immediately underlying shale seal:thickness of } \\
\text { potential reservoir sand:thickness of immediately overlying shale seal. }\end{array}$ & $\begin{array}{l}2.00: 1: 0.18 \\
0.40: 1: 0.40 \\
0.58: 1: 1.75 \\
5.25: 1: 7.25 \\
1.38: 1: 0.48 \\
0.27: 1: 0.43 \\
3.20: 1: 2.00\end{array}$ & $0.33: 1: 3.33$ & $\begin{array}{l}1.00: 1: 0.86 \\
1.00: 1: 1.33 \\
1.33: 1: 2.00 \\
0.88: 1: 0.63 \\
3.17: 1: 0.67\end{array}$ \\
\hline Depth to top of uppermost potential reservoir sand (SLD) & 2,837 & 4,197 & 5,185 \\
\hline Depth to top of lowermost potential reservoir sand (SLD) & 3,902 & 4,197 & 6,512 \\
\hline Average depth to top of unit's potential reservoir sand (SLD) & 3,389 & 4,197 & 6,097 \\
\hline Percent of potential reservoir sand in upper third of unit & 45 & 100 & 43 \\
\hline Percent of potential reservoir sand in middle third of unit & 26 & 0 & 36 \\
\hline Percent of potential reservoir sand in lower third of unit & 29 & $\mathbf{0}$ & 21 \\
\hline $\begin{array}{l}\mathrm{D} / \mathrm{PR} \text { factor (average depth of potential reservoir sand occurrence/total thick- } \\
\text { ness of unit's potential reservoir sand). }\end{array}$ & 7 & 70 & 37 \\
\hline
\end{tabular}

Geophysical logs: Electric

Well No.: MD-QA-T-15

Record No.: 3129

Well name: USGS Test, Chestertown

State: Maryland

Latitude: 391203

County: Queen Annes

Longitude: 0760243

Depth of well__..ft___ 1,995

- $1,995-1,970$

Elevation of measuring point above ground level_._. $\mathrm{ft}_{\ldots} \ldots{ }_{-} 3$

Elevation of ground level_._._ft__._.22

\begin{tabular}{|c|c|c|c|}
\hline Potential reservoir sand determination & Unit $\mathbf{F}$ & Unit $\mathbf{G}$ & Unit $\mathbf{H}$ \\
\hline Depth to top of unit (SLD) & -349 & -752 & $-1,153$ \\
\hline Thickness of unit (feet) & 403 & 401 & 794 \\
\hline Unit's total sand thickness (feet/percent) & $78 / 19$ & $114 / 28$ & $359 / 45$ \\
\hline Unit's total shale thickness (feet/percent) & $325 / 81$ & $287 / 72$ & $435 / 55$ \\
\hline Unit's sand-shale ratio & 0.2 & 0.4 & 0.8 \\
\hline Number of potential reservoir sands in unit & 0 & 0 & 2 \\
\hline Total thickness (feet) of unit's potential reservoir sands & -------- & --------- & 86 \\
\hline Average thickness (feet) of unit's potential reservoir sands & -------- & ------- & 43 \\
\hline Maximum thickness (feet) of a potential reservoir sand layer in unit & ------ & --------- & 46 \\
\hline Ratio-unit's potential reservoir sand thickness:unit's total thickness & -------- & -------- & 0.06 \\
\hline Ratio-unit's potential reservoir sand thickness:unit's total sand thickness & ------- & --------- & 0.24 \\
\hline $\begin{array}{l}\text { Thickness (feet)-Immediately underlying shale seal-potential reservoir sand- } \\
\text { immediately overlying shale seal. }\end{array}$ & & & $76-46-108$ \\
\hline $\begin{array}{l}\text { Ratio (feet) -Thickness of immediately underlying shale seal:thickness of } \\
\text { potential reservoir sand:thickness of immediately overlying shale seal. }\end{array}$ & & & $\begin{array}{l}1.65: 1: 2.35 \\
1.60: 1: 1.90\end{array}$ \\
\hline Depth to top of uppermost potential reservoir sand (SLD) & & & 1,495 \\
\hline Depth to top of lowermost potential reservoir sand (SLD) & ------- & --1 & 1,620 \\
\hline Average depth to top of unit's potential reservoir sand (SLD) & -------- & --- & 1,558 \\
\hline Percent of potential reservoir sand in upper third of unit & ------ & ------- & $\mathbf{0}$ \\
\hline Percent of potential reservoir sand in middle third of unit & ------- & -------- & 53 \\
\hline Percent of potential reservoir sand in lower third of unit & $-\cdots---$ & & 47 \\
\hline $\begin{array}{l}\text { D/PR factor (average depth of potential reservoir sand occurrence/total thick- } \\
\text { ness of unit's potential reservoir sand). }\end{array}$ & None & None & 18 \\
\hline
\end{tabular}

Geophysical logs: Electric, Gamma

Well No.: DEL-SUS-OT-5

Record No.: 4000

State: Delaware

County: Sussex
Well name: Sun Oil Co., Apple Orchard D-6 Latitude: 384325 Longitude: 0753200

Depth of well-_ft-_-2,585

Depth of well (SLD)

Elevation of measuring point above ground level _... $\mathrm{ft}_{\ldots} \ldots$

Elevation of ground level .....ft_....25

\begin{tabular}{|c|c|c|c|}
\hline Potential reservoir sand determination & Unit $\mathbf{F}$ & Unit G & Unit $\mathbf{H}$ \\
\hline Depth to top of unit (SLD) & $-1,630$ & Absent & Absent \\
\hline Thickness of unit (feet) & $>930$ & $-\ldots-n---$ & --------- \\
\hline Unit's total sand thickness (feet/percent) - & $262 / 28$ & $---n---n-$ & -------- \\
\hline Unit's total shale thickness (feet/percent) - & $658 / 71$ & --------- & -------- \\
\hline Unit's sand-shale ratio & 0.4 & --------- & -------- \\
\hline Number of potential reservoir sands in unit & 1 & $---n----$ & -------- \\
\hline Total thickness (feet) of unit's potential reservoir sands & 40 & -------- & -------- \\
\hline Average thickness (feet) of unit's potential reservoir sands & 40 & ------- & -------- \\
\hline Maximum thickness (feet) of a potential reservoir sand layer in & 40 & & \\
\hline
\end{tabular}


Well No.: DEL-SUS-OT-5-Continued

\begin{tabular}{|c|c|c|c|}
\hline Potential reservoir sand determination-Continued & Unit $\mathbf{F}$ & Unit $\mathrm{G}$ & Unit $\mathbf{H}$ \\
\hline Ratio-unit's potential reservoir sand thickness:unit's total thickness & 0.04 & -- & \\
\hline Ratio-unit's potential reservoir sand thickness:unit's total sand thickness & 0.15 & --- & \\
\hline $\begin{array}{l}\text { Thickness (feet)-Immediately underlying shale seal-potential reservoir sand- } \\
\text { immediately overlying shale seal. }\end{array}$ & $35-40-24$ & -- & \\
\hline $\begin{array}{l}\text { Ratio (feet) - Thickness of immediately underlying shale seal:thickness of } \\
\text { potential reservoir sand:thickness of immediately overlying shale seal. }\end{array}$ & $0.88: 1: 0.60$ & & \\
\hline Depth to top of uppermost potential reservoir sand (SLD) & 1,835 & --- & \\
\hline Depth to top of lowermost potential reservoir sand (SLD) & 1,835 & ----- & -- \\
\hline Average depth to top of unit's potential reservoir sand (SLD) & 1,835 & $----\ldots--$ & \\
\hline Percent of potential reservoir sand in upper third of unit & 100 & & \\
\hline Percent of potential reservoir sand in middle third of unit & 0 & -- & \\
\hline Percent of potential reservoir sand in lower third of unit & 0 & & \\
\hline $\begin{array}{l}\text { D/PR factor (average depth of potential reservoir sand occurrence/total thick- } \\
\text { ness of unit's potential reservoir sand). }\end{array}$ & 46 & --------- & --- - - - \\
\hline
\end{tabular}

Geophysical logs: Electric

Well No.: DEL-NC-T-1

Record No.: 4011

State: Delaware

Well name: Tidewater Oil Co., Vogel No. 2

County: New Castle

Latitude: 392215

Depth of well_._ft_-_-2,312

Depth of well (SLD) _.....ft__._2,286

Elevation of measuring point above ground level..... $\mathrm{ft}_{-.-{ }_{-} 4}$

Elevation of ground level _...ft_...22

\begin{tabular}{|c|c|c|c|}
\hline Potential reservoir sand determination & Unit $F$ & Unit $\mathrm{G}$ & Unit $\mathrm{H}$ \\
\hline Depth to top of unit (SLD) & -639 & $-1,361$ & $-1,764$ \\
\hline Thickness of unit (feet) & 722 & 403 & 515 \\
\hline Unit's total sand thickness (feet/percent) & $240 / 33$ & $90 / 22$ & $210 / 41$ \\
\hline Unit's total shale thickness (feet/percent) & $482 / 67$ & $313 / 78$ & $305 / 59$ \\
\hline Unit's sand-shale ratio & 0.5 & 0.3 & 0.7 \\
\hline Number of potential reservoir sands in unit & 4 & 0 & 0 \\
\hline Total thickness (feet) of unit's potential reservoir sands & 120 & -...-- & $\ldots$ \\
\hline Average thickness (feet) of unit's potential reservoir sands & 30 & -..--..-.. & $\ldots$ \\
\hline Maximum thickness (feet) of a potential reservoir sand layer in unit & 50 & -------- & -....... \\
\hline Ratio-unit's potential reservoir sand thickness:unit's total thickness & 0.17 & ---------- & --- \\
\hline Ratio-unit's potential reservoir sand thickness:unit's total sand thickness & 0.50 & - - - - - - & -- \\
\hline $\begin{array}{l}\text { Thickness (feet)-Immediately underlying shale seal-potential reservoir sand- } \\
\text { immediately overlying shale seal. }\end{array}$ & $\begin{array}{r}150-30-20 \\
60-20-20 \\
70-20-40 \\
40-50-30\end{array}$ & ------- & \\
\hline $\begin{array}{l}\text { Ratio (feet)-Thickness of immediately underlying shale seal:thickness of } \\
\text { potential reservoir sand:thickness of immediately overlying shale seal. }\end{array}$ & $\begin{array}{l}5.00: 1: 0.67 \\
2.00: 1: 1.00 \\
3.50: 1: 2.00 \\
0.80: 1: 0.60\end{array}$ & ---- & \\
\hline Depth to top of uppermost potential reservoir sand (SLD) -- & 979 & 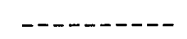 & ------ \\
\hline Depth to top of lowermost potential reservoir sand (SLD) & 1,334 & --------- & $----\cdots-1$ \\
\hline Average depth to top of unit's potential reservoir sand (SLD) & 1,144 & -------- & ---- \\
\hline Percent of potential reservoir sand in upper third of unit & 0 & -------- & ---- \\
\hline $\begin{array}{l}\text { Percent of potential reservoir sand in middle third of unit } \\
\text { Percent of potential reservoir sand in lower third of unit }\end{array}$ & 58 & -------- & ------- \\
\hline $\begin{array}{l}\text { Percent of potential reservoir sand in lower third of unit } \\
\text { D/PR factor (average depth of potential reservoir sand occurrence/total thick- }\end{array}$ & 42 & ------ & \\
\hline $\begin{array}{l}\text { D/PR factor (average depth of potential reservoir sand occurrence/total thick- } \\
\text { ness of unit's potential reservoir sand). }\end{array}$ & 10 & None & None \\
\hline
\end{tabular}

Geophysical logs: Electric, Gamma

Well No.: NJ-CM-OT-1

Record No.: 5000

State: New Jersey

County: Cape May
Well name: Anchor Gas Co., Dickinson No. 1

Latitude: 385720

Longitude: 0745700

Depth of well _..ft_-_6,410

Depth of well (SLD) - - ft__-_6,388

Elevation of measuring point above ground level _....ft ..... 8

Elevation of ground level_....ft_...14

\begin{tabular}{|c|c|c|c|}
\hline Potential reservoir sand determination & Unit F & Unit $\mathrm{G}$ & Unit $\mathbf{H}$ \\
\hline Depth to top of unit (SLD) & $-2,420$ & $-3,544$ & $-4,522$ \\
\hline Thickness of unit (feet) & 1,124 & 998 & 1,776 \\
\hline Unit's total sand thickness (feet/percent). & $390 / 35$ & $265 / 27$ & $1,206 / 68$ \\
\hline Unit's total shale thickness (feet/percent) & $734 / 65$ & $713 / 71$ & $570 / 32$ \\
\hline Unit's sand-shale ratio & 0.5 & 0.4 & 2.1 \\
\hline Number of potential reservoir sands in unit & 2 & 2 & 3 \\
\hline Total thickness (feet) of unit's potential rese & 110 & $7 \overrightarrow{4}$ & 98 \\
\hline
\end{tabular}


Well No.: NJ-CM-OT-1-Continued

\begin{tabular}{|c|c|c|c|}
\hline Potential reservoir sand determination-Continued & Unit $\mathbf{F}$ & Unit $\mathbf{G}$ & Unit $\mathbf{H}$ \\
\hline Average thickness (feet) of unit's potential reservoir sands & 55 & 37 & 33 \\
\hline Maximum thickness (feet) of a potential reservoir sand layer in unit & 80 & 42 & 48 \\
\hline Ratio-unit's potential reservoir sand thickness: unit's total thickness & 0.10 & 0.07 & 0.06 \\
\hline Ratio-unit's potential reservoir sand thickness:unit's total sand thickness & 0.21 & 0.28 & 0.08 \\
\hline $\begin{array}{l}\text { Thickness (feet)-Immediately underlying shale seal-patential reservoir sand- } \\
\text { immediately overlying shale seal. }\end{array}$ & $\begin{array}{l}23-80-55 \\
34-30-32\end{array}$ & $\begin{array}{l}26-42-25 \\
38-32-36\end{array}$ & $20-30-36$ \\
\hline Ratio (feet)-Thickness of immediately underlying shale seal:thickness of & $0.29: 1: 0.69$ & $0.62: 1: 0.60$ & $0.67: 1: 1.20$ \\
\hline potential reservoir sand:thickness of immediately overlying shale seal. & $1.13: 1: 1.07$ & $1.19: 1: 1.13$ & $0.42: 1: 0.52$ \\
\hline Depth to top of uppermost potential reservoir sand (SLD) & 2,452 & 3,890 & 4,588 \\
\hline Depth to top of lowermost potential reservoir sand (SLD) & 3,076 & 4,500 & 6,030 \\
\hline Average depth to top of unit's potential reservoir sand (SLD) & 2,764 & 4,195 & 5,513 \\
\hline Percent of potential reservoir sand in upper third of unit & 27 & 43 & 20 \\
\hline Percent of potential reservoir sand in middle third of unit & 73 & 0 & 0 \\
\hline Percent of potential reservoir sand in lower third of unit & 0 & 57 & 80 \\
\hline $\mathrm{D} / \mathrm{PR}$ factor (average depth of potential reservoir sand occurrence/total thick- & 25 & 56 & 56 \\
\hline
\end{tabular}

Geophysical logs : Electric, Gamma

Well No.: NJ-CU-OT-8

Record No. 5010

State: New Jersey

Well name: Anchor Gas Co., Ragovin No. 1

Latitude: 392530

County: Cumberland

Longitude: 0745225

Depth of well__-_ft_-_-3,717

Depth of well (SLD) -_-_ft_-_-3,623

Elevation of measuring point above ground level__._. $\mathrm{ft}_{-}$

Elevation of ground level_..-.ft.--.85

\begin{tabular}{|c|c|c|c|}
\hline Potential reservoir sand determination & Unit $\mathbf{F}$ & Unit $\mathbf{G}$ & Unit $\mathbf{H}$ \\
\hline Depth to top of unit (SLD) & $-1,667$ & $-2,413$ & $-3,108$ \\
\hline Thickness of unit (feet) & 746 & 695 & 508 \\
\hline Unit's total sand thickness (feet/percent) & $220 / 29$ & $120 / 17$ & $278 / 55$ \\
\hline Unit's total shale thickness (feet/percent) - & $526 / 71$ & $575 / 83$ & $230 / 45$ \\
\hline Unit's sand-shale ratio & 0.4 & 0.2 & 1.2 \\
\hline Number of potential reservoir sands in unit & 0 & 1 & 0 \\
\hline Total thickness (feet) of unit's potential reservoir sands -- & -- & 20 & -- \\
\hline Average thickness (feet) of unit's potential reservoir sands & & 20 & \\
\hline Maximum thickness (feet) of a potential reservoir sand layer in unit & ------ & 20 & -- \\
\hline Ratio - unit's potential reservoir sand thickness:unit's total thickness & & 0.03 & \\
\hline Ratio-unit's potential reservoir sand thickness: unit's total sand thickness & & 0.17 & \\
\hline $\begin{array}{l}\text { Thickness (feet)-Immediately underlying shale seal-potential reservoir sand- } \\
\text { immediately overlying shale seal. }\end{array}$ & & 75-20-110 & ----- \\
\hline $\begin{array}{l}\text { Ratio (feet) - Thickness of immediately underlying shale seal:thickness of } \\
\text { potential reservoir sand:thickness of immediately overlying shale seal. }\end{array}$ & & $3.75: 1: 5.50$ & \\
\hline Depth to top of uppermost potential reservoir sand (SLD) & & 2,919 & \\
\hline Depth to top of lowermost potential reservoir sand (SLD) & & 2,919 & \\
\hline Average depth to top of unit's potential reservoir sand (SLD) & & 2,919 & \\
\hline Percent of potential reservoir sand in upper third of unit & & 0 & \\
\hline Percent of potential reservoir sand in middle third of unit & & 0 & -- \\
\hline Percent of potential reservoir sand in lower third of unit & & 100 & \\
\hline D/PR factor (average depth of potential reservoir sand occurrence/total thick- & None & 146 & None \\
\hline
\end{tabular}

Geophysical logs: Electric, Gamma Ray-Neutron

Well No.: NJ-CAM-T-2

Record No.: 5022

State: New Jersey

County: Camden
Well name: USGS Test, New Brooklyn State Park Latitude: 394230 Longitude: 0745615

Depth of well _...ft_--_2,090

Depth of well (SLD) ---ft_--1,979

Elevation of measuring point above ground level_..._ft_.._o

Elevation of ground level.....ft.....111

\begin{tabular}{|c|c|c|c|}
\hline Potential reservoir sand determination & Unit F & Unit $\mathbf{G}$ & Unit $\mathbf{H}$ \\
\hline Depth to top of unit (SLD) & -881 & $-1,727$ & Absent \\
\hline Thickness of unit (feet) & 846 & 192 & -------- \\
\hline Unit's total sand thickness (feet/percent) & $390 / 46$ & $70 / 36$ & ------- \\
\hline Unit's total shale thickness (feet/percent) - & $456 / 54$ & $122 / 64$ & \\
\hline Unit's sand-shale ratio & 0.9 & 0.6 & ------ \\
\hline Number of potential reservoir sands in unit & 2 & 0 & \\
\hline Total thickness (feet) of unit's potential reservoir sands -- & 71 & --------- & \\
\hline
\end{tabular}


Well No.: NJ-CAM-T-2-Continued

\begin{tabular}{|c|c|c|c|}
\hline Potential reservoir sand determination-Continued & Unit $F$ & Unit G & Unit $\mathbf{H}$ \\
\hline Average thickness (feet) of unit's potential reservoir sands & 36 & $-\ldots-\ldots-n$ & \\
\hline Maximum thickness (feet) of a potential reservoir sand layer in unit & 36 & ---_--.--- & ------- \\
\hline Ratio-unit's potential reservoir sand thickness:unit's total thickness & 0.08 & -......... & \\
\hline Ratio-unit's potential reservoir sand thickness: unit's total sand thickness ---- & 0.18 & $-\ldots-\ldots-.-$ & -.-.-.-.- \\
\hline $\begin{array}{l}\text { Thickness (feet-Immediately underlying shale seal-potential reservoir sand- } \\
\text { immediately overlying shale seal. }\end{array}$ & $\begin{array}{l}30-35-32 \\
38-36--45\end{array}$ & $-----n--$ & \\
\hline $\begin{array}{l}\text { Ratio (feet) - Thickness of immediately underlying shale seal:thickness of } \\
\text { potential reservoir sand:thickness of immediately overlying shale seal. } \\
\text { Depth to top of uppermost potential reservoir sand (SLD) }\end{array}$ & $\begin{array}{l}0.86: 1: 0.91 \\
1.06: 1: 1.25 \\
1,055\end{array}$ & & \\
\hline Depth to top of lowermost potential reservoir sand (SLD) & 1,542 &.------ & 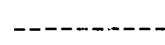 \\
\hline Average depth to top of unit's potential reservoir sand (SLD) & 1,299 & -------- & $---\cdots-1-1$ \\
\hline Percent of potential reservoir sand in upper third of unit & 51 & $-\ldots---.-$ & 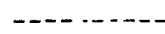 \\
\hline Percent of potential reservoir sand in middle third of unit & 0 & -------- & $-\ldots-\ldots$ \\
\hline Percent of potential reservoir sand in lower third of unit & 49 & $\ldots$ & -..-.... \\
\hline $\begin{array}{l}\text { D/PR factor (average depth of potential reservoir sand occurrence/total thick- } \\
\text { ness of unit's potential reservoir sand). }\end{array}$ & 18 & None & --n-1-- \\
\hline
\end{tabular}

Geophysical logs: Electric, Gamma

Well No.: NJ-BU-T-4

Record No.: 5037

State: New Jersey

Well name: Butler Place, USGS Test

County: Burlington

Latitude: 395145

Longitude: 0743025

Depth of well
Depth of well (SLD)

Flevation of measuring point above ground level_... $\mathrm{ft}_{\ldots}$

Elevation of ground level _..._t_._._132

\begin{tabular}{|c|c|c|c|}
\hline Potential reservoir sand determination & Unit F & Unit $\mathbf{G}$ & Unit $\mathbf{H}$ \\
\hline Depth to top of unit (SLD) & $-1,234$ & $-1,729$ & Absent \\
\hline Thickness of unit (feet) & 495 & 385 & -------- \\
\hline Unit's total sand thickness (feet/percent) & $210 / 42$ & $200 / 52$ & -------- \\
\hline Unit's total shale thickness (feet/percent) & $275 / 56$ & $185 / 48$ & -------1 \\
\hline Unit's sand-shale ratio & 0.8 & 1.1 & ---- \\
\hline Number of potential reservoir sands in unit & 2 & 0 & ------ \\
\hline Total thickness (feet) of unit's potential reservoir sands & 72 & $----n-n--$ & ----- \\
\hline Average thickness (feet) of unit's potential reservoir sands & 36 & ------- & ------ \\
\hline Maximum thickness (feet) of a potential reservoir sand layer in unit & 48 & -------- & \\
\hline Ratio-unit's potential reservoir sand thickness: unit's total thickness _- & 0.15 & --------- & ----- \\
\hline Ratio-unit's potential reservoir sand thickness:unit's total sand thickness & 0.34 & -------- & ---- \\
\hline $\begin{array}{l}\text { Thickness (feet) -Immediately underlying shale seal-potential reservoir sand- } \\
\text { immediately overlying shale seal. }\end{array}$ & $\begin{array}{l}60-48-25 \\
46-24-21\end{array}$ & --- & \\
\hline Ratio (feet)-Thickness of immediately underlying shale seal:thickness of & $1.25: 1: 0.52$ & & \\
\hline potential reservoir sand:thickness of immediately overlying shale seal. & 1.92:1:0.88 & & \\
\hline Depth to top of uppermost potential reservoir sand (SLD) & 1,400 & & \\
\hline Depth to top of lowermost potential reservoir sand (SLD) & 1,600 & - & \\
\hline Average depth to top of unit's potential reservoir sand (SLD) & 1,540 & -------- & ---- \\
\hline Percent of potential reservoir sand in upper third of unit & $\mathbf{0}$ & -------1 & ---- \\
\hline Percent of potential reservoir sand in middle third of unit & 33 & & \\
\hline Percent of potential reservoir sand in lower third of unit & 67 & & --- \\
\hline D/PR factor (average depth of potential reservoir sand occurrence/total thick- & 21 & None & \\
\hline
\end{tabular}
ness of unit's potential reservoir sand).

Geophysical logs: Electric, Gamma Ray-Neutron, Sonic

Well No.: NJ-OC-T-12

Record No.: 5044

State: New Jersey

County: Ocean
Well name: Toms River Chemical Test 84

Latitude: 395845

Longitude: 0741520

Depth of well---ft---2,254

Depth of well (SLD)

Elevation of measuring point above ground level

Elevation of ground level..... $\mathrm{ft}_{\text {. }}$. $_{65}$

\begin{tabular}{|c|c|c|c|}
\hline Potential reservoir sand determination & Unit $\mathbf{F}$ & Unit $\mathbf{G}$ & Unit $\mathbf{H}$ \\
\hline Depth to top of unit (SLD) & $-1,532$ & $-2,072$ & Absent \\
\hline Thickness of unit (feet) & 540 & & - - - - - - - - - \\
\hline Unit's total sand thickness (feet/percent) & $236 / 44$ & $---n-n--$ & $-\ldots$ \\
\hline Unit's total shale thickness (feet/percent) & $304 / 56$ & ------- & --------- \\
\hline Unit's sand-shale ratio & 0.8 & - - - - - - - & $-------n$ \\
\hline Number of potential reservoir sands in unit & 2 & -------1 & 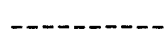 \\
\hline Total thickness (feet) of unit's potential reservoir sands & 52 & $-\infty-1$ & \\
\hline
\end{tabular}


Well No.: NJ-OC-T-12-Continued

Unit G

Unit $\mathbf{H}$

Average thickness (feet) of unit's potential reservoir sands

Maximum thickness (feet) of a potential reservoir sand layer in unit -

Ratio-unit's potential reservoir sand thickness:unit's total thickness _-

Ratio_unit's potential reservoir sand thickness:unit's total sand thickness _...

Thickness (feet) - Immediately underlying shale seal-potential reservoir sandimmediately overlying shale seal.

Ratio (feet)-Thickness of immediately underlying shale seal:thickness of potential reservoir sand:thickness of immediately overlying shale seal.

Depth to top of uppermost potential reservoir sand (SLD)

Depth to top of lowermost potential reservoir sand (SLD)

Average depth to top of unit's potential reservoir sands ( $\bar{S} \bar{L} \bar{D})$

Percent of potential reservoir sand in upper third of unit

Percent of potential reservoir sand in middle third of unit

Percent of potential reservoir sand in lower third of unit ness of unit's potential reservoir sand).

26
32
0.10
0.22
$20-32-30$
$23-20-20$
$0.63: 1: 1.07$
$1.15: 1: 1.00$
1,618
1,982
1,800
38
0
62
35

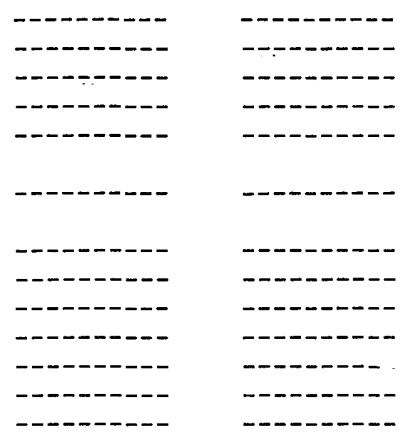

Geophysical logs: Electric, Gamma

Well No.: NJ-OC-T-1

Record No.: 5049

State: New Jersey

County: Ocean

Well name: Island Beach USGS Test

Depth of well

Depth of well (SLD) _....ft_.-. 3,86

Elevation of measuring point above ground level_..._ft._._.3

Elevation of ground level_....ft_..-10

\begin{tabular}{|c|c|c|c|}
\hline Potential reservoir sand determination & Unit F & Unit G & Unit $\mathbf{H}$ \\
\hline Depth to top of unit (SLD) & $-2,362$ & $-2,966$ & $-3,327$ \\
\hline Thickness of unit (feet) & 604 & 361 & 517 \\
\hline Unit's total sand thickness (feet/percent) & $360 / 60$ & $100 / 28$ & $317 / 61$ \\
\hline Unit's total shale thickness (feet/percent) & $244 / 40$ & $261 / 72$ & $200 / 39$ \\
\hline Unit's sand-shale ratio & 1.5 & 0.4 & 1.6 \\
\hline Number of potential reservoir sands in unit & 1 & $\mathbf{3}$ & 0 \\
\hline Total thickness (feet) of unit's potential reservoir sands & 24 & 100 & \\
\hline Average thickness (feet) of unit's potential reservoir sands & 24 & 33 & \\
\hline Maximum thickness (feet) of a potential reservoir sand layer in unit & 24 & 38 & \\
\hline Ratio-unit's potential reservoir sand thickness:unit's total thickness & 0.04 & 0.28 & \\
\hline Ratio-unit's potential reservoir sand thickness:unit's total sand thickness & 0.07 & 1.00 & \\
\hline $\begin{array}{l}\text { Thickness (feet) - Immediately underlying shale seal-potential reservoir sand- } \\
\text { immediately overlying shale seal. }\end{array}$ & $66-24-26$ & $\begin{array}{r}146-28-64 \\
64-34-24 \\
24-38-30\end{array}$ & \\
\hline $\begin{array}{l}\text { Ratio (feet)-Thickness of immediately underlying shale seal:thickness of } \\
\text { potential reservoir sand:thickness of immediately overlying shale seal. }\end{array}$ & $2.75: 1: 1.08$ & $\begin{array}{l}5.21: 1: 2.29 \\
1.88: 1: 0.71 \\
0.63: 1: 0.79\end{array}$ & \\
\hline Depth to top of uppermost potential reservoir sand (SLD) & 2,612 & 2,997 & \\
\hline Depth to top of lowermost potential reservoir sand (SLD) & 2,612 & 3,153 & \\
\hline Average depth to top of unit's potential reservoir sands (SLD) & 2,612 & 3,075 & \\
\hline Percent of potential reservoir sand in upper third of unit & 0 & 72 & \\
\hline Percent of potential reservoir sand in middle third of unit & 100 & 28 & \\
\hline Percent of potential reservoir sand in lower third of unit & $\mathbf{0}$ & $\mathbf{0}$ & \\
\hline $\begin{array}{l}\text { D/PR factor (average depth of potential reservoir sand occurrence/total thick- } \\
\text { ness of unit's potential reservoir sand). }\end{array}$ & 109 & 93 & None \\
\hline
\end{tabular}

\footnotetext{
Geophysical logs: Electric, Gamma Ray-Neutron, Sonic
} 
